$\mathrm{JE} / \mathrm{ER}-4$

\title{
Independent Criticality Safety Evaluation of Deposits in Cooler Equipment in Building K-31 at the Oak Ridge K-25 Site, Oak Ridge, Tennessee
}

\section{031298 \\ OSTI}




\section{DISCLAMMER}

Portions of this document may be illegible in electronic image products. Images are produced from the best available original document. 


\section{DISCLAIMER}

This report was prepared as an account of work sponsored by an agency of the United States Government. Neither the United States Government nor any agency thereof, nor any of their employees, makes any warranty, express or implied, or assumes any legal liability or responsibility for the accuracy, completeness, or usefulness of any information, apparatus, product, or process disclosed, or represents that its use would not infringe privately owned rights. Reference herein to any specific commercial product, process, or service by trade name, trademark, manufacturer, or otherwise does not necessarily constitute or imply its endorsement, recommendation, or favoring by the United States Government or any agency thereof. The views and opinions of authors expressed herein do not necessarily state or reflect those of the United States Government or any agency thereof. 


\title{
Independent Criticality Safety Evaluation of Deposits in Cooler Equipment in Building K-31 at the Oak Ridge K-25 Site, Oak Ridge, Tennessee
}

Date Issued-October 1996

\author{
Prepared by \\ Jacobs ER Team \\ 125 Broadway Avenue \\ Oak Ridge, Tennessee \\ under contract DE-AC05-93OR22028 \\ Prepared for \\ U.S. Department of Energy \\ Office of Environmental Restoration and Waste Management
}




\section{PREFACE}

This Independent Criticality Safety Evaluation of Deposits in Cooler Equipment in Building $K-31$ at the Oak Ridge $K-25$ Site, Oak Ridge, Tennessee (JE/ER-4) was prepared in accordance with requirements under the Comprehensive Environmental Response, Compensation, and Liability Act of 1980 for documentation of activities for the safety evaluation. This work was performed under Work Breakdown Structure 1.4.12.4.2.01 (Activity Data Sheet 4701). This document provides the Environmental Restoration Program with information regarding nuclear criticality issues of deposits in the 6A Booster Station coolers in Building K-31. 


\section{CONTENTS}

FIGURES $\ldots \ldots \ldots \ldots \ldots \ldots \ldots \ldots \ldots \ldots \ldots \ldots \ldots \ldots \ldots$

TABLES $\ldots \ldots \ldots \ldots \ldots \ldots \ldots \ldots \ldots \ldots \ldots \ldots \ldots \ldots$

ACRONYMS AND ABBREVIATIONS $\ldots \ldots \ldots \ldots \ldots \ldots \ldots \ldots$ vii

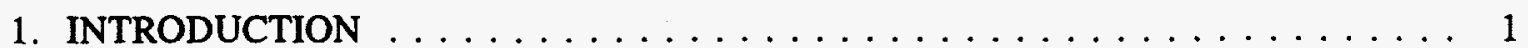

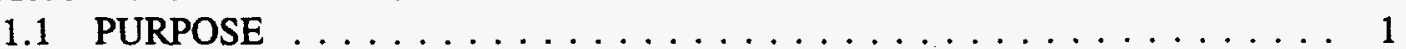

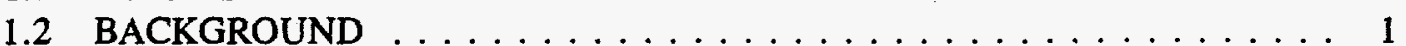

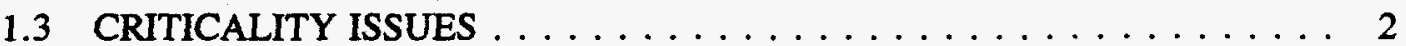

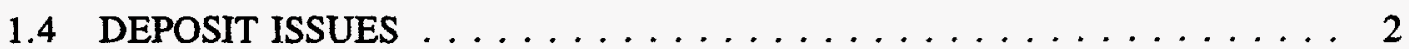

1.4.1 NDA Measurement of Deposit $\ldots \ldots \ldots \ldots$

1.4 .2 Deliquescence $\ldots \ldots \ldots \ldots \ldots \ldots \ldots \ldots$

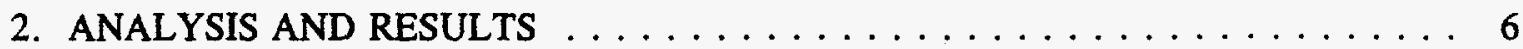

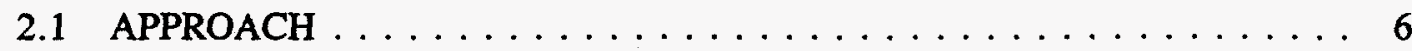

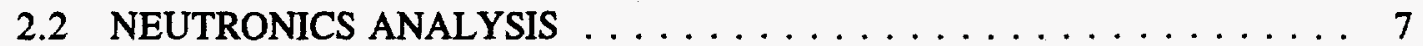

2.2.1 West Cooler for the 6A Booster Station in Building K-31 . . . . 7

2.2.1.1 Detailed analysis ............... 10

2.2.1.2 Deposit deliquescence ............... 16

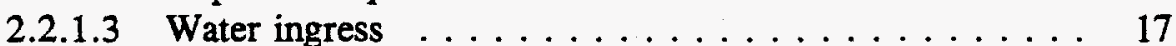

2.2.2 East Cooler for the 6A Booster Station in Building $\mathrm{K}-31 \ldots \ldots$

2.2.2.1 Detailed analysis . . . . . . . . . . . . . 19

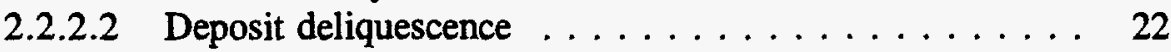

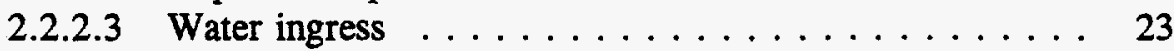

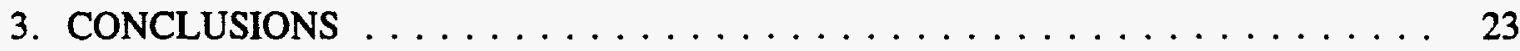

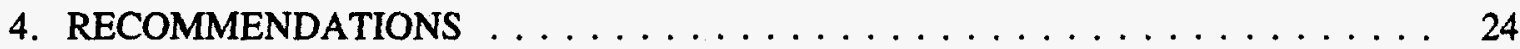

5. MEETING PROGRAM OBJECTIVES $\ldots \ldots \ldots \ldots \ldots \ldots \ldots \ldots$

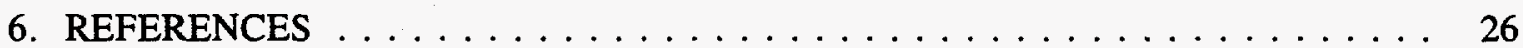

APPENDIX A: $\quad$ FAULT TREE ANALYSIS $\ldots \ldots \ldots \ldots \ldots \ldots \ldots$ A-1 APPENDIX B: COMMENTS AND RESPONSES, INDEPENDENT EVALUATION OF CRITICALITY ISSUES ASSOCIATED WITH URANIUM DEPOSITS AT THE K-25 SITE, OAK RIDGE, TENNESSEE _ . . B-1 


\section{FIGURES}

Figure No.

Page

1. Cooler specifications $\ldots \ldots \ldots \ldots \ldots \ldots \ldots \ldots \ldots \ldots \ldots \ldots \ldots$

\section{TABLES}

1. Partial pressure of water in air $\ldots \ldots \ldots \ldots \ldots \ldots \ldots \ldots \ldots$

2. Calculated $\mathrm{k}_{\mathrm{eff}}$ results for a uniform deposit distribution of $5,025 \mathrm{~g}$ of ${ }^{235} \mathrm{U}$ with present conditions ...................... 10

3. Calculated $\mathrm{k}_{\mathrm{eff}}$ results for a lumped deposit distribution of $5,025 \mathrm{~g}$ of ${ }^{235} \mathrm{U}$ with

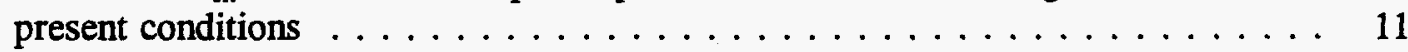

4. Calculated $k_{\text {eff }}$ results for a chord deposit distribution of $5,025 \mathrm{~g}$ of ${ }^{235} \mathrm{U}$ with

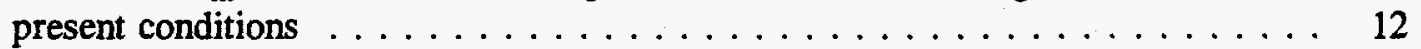

5. Calculated $k_{\text {eff }}$ results for an ellipsoidal deposit distribution of $5,025 \mathrm{~g}$ of ${ }^{235} \mathrm{U}$ with present conditions . . . . . . . . . . . . . . . . 12

6. Calculated $k_{\text {eff }}$ results for a uniform deposit distribution of $5,025 \mathrm{~g}$ of ${ }^{235} \mathrm{U}$ with

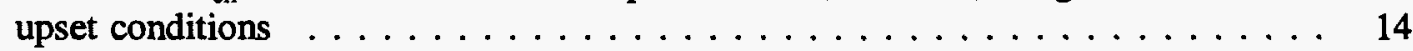

7. Calculated $\mathrm{k}_{\mathrm{eff}}$ results for a lumped deposit distribution of $5,025 \mathrm{~g}$ of ${ }^{235} \mathrm{U}$ with

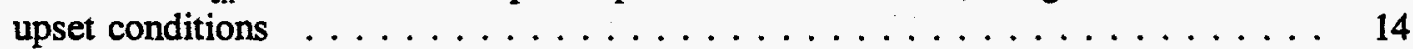

8. Calculated $k_{\text {eff }}$ results for a chord deposit distribution of $5,025 \mathrm{~g}$ of ${ }^{235} \mathrm{U}$ with

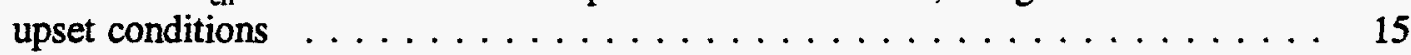

9. Calculated $\mathrm{k}_{\mathrm{eff}}$ results for an ellipsoidal deposit distribution of $5,025 \mathrm{~g}$ of ${ }^{225} \mathrm{U}$

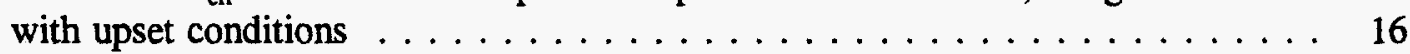

10. Calculated $k_{\text {eff }}$ results for a chord deposit distribution of $2,664 \mathrm{~g}$ of ${ }^{235} \mathrm{U}$ with present conditions . . . . . . . . . . . . . . . . . 20

11. Calculated $\mathrm{k}_{\text {eff }}$ results for an ellipsoidal deposit distribution of $2,664 \mathrm{~g}$ of ${ }^{225} \mathrm{U}$ with present conditions . . . . . . . . . . . . . . . . 20

12. Calculated $k_{\text {eff }}$ results for a chord deposit distribution of $2,664 \mathrm{~g}$ of ${ }^{235} \mathrm{U}$ with upset conditions ........................ 21

13. Calculated $\mathrm{k}_{\text {eff }}$ results for an ellipsoidal deposit distribution of $2,664 \mathrm{~g}$ of ${ }^{235} \mathrm{U}$

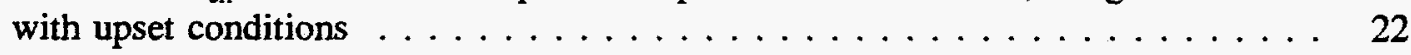




\title{
ACRONYMS AND ABBREVIATIONS
}

ANS
${ }^{\circ} \mathrm{C}$
$\mathrm{cm}$
DOE
Energy Systems
${ }^{\circ} \mathrm{F}$
$\mathrm{ft}$
$\mathrm{FTA}$
$\mathrm{g}$
$\mathrm{H}$
$\mathrm{H} / \mathrm{U}$
$\mathrm{H}{ }_{2} \mathrm{O}$
in.
$\mathrm{k}_{\mathrm{eff}}$
$\mathrm{m}$
$\mathrm{MCNP}$
$\mathrm{NDA}^{\circ}$
$\mathrm{ORNL}$
torr
$\mathrm{U}$
$\mathrm{UF}{ }_{6}$
$\mathrm{UO} \mathrm{F}_{2}$
$\mathrm{XH}_{2} \mathrm{O}$

\author{
American Nuclear Society \\ degrees Celsius \\ centimeter \\ U.S. Department of Energy \\ Lockheed Martin Energy Systems \\ degrees Fahrenheit \\ foot \\ fault tree analysis \\ gram \\ hydrogen \\ hydration ratio \\ water \\ inch \\ effective multiplication factor \\ meter \\ Monte Carlo N-Particle Transport Code \\ nondestructive assay \\ Oak Ridge National Laboratory \\ unit of pressure \\ uranium \\ uranium hexafluoride \\ uranyl fluoride \\ number of water molecules
}




\section{INTRODUCTION}

\subsection{PURPOSE}

This report provides an independent assessment of nuclear criticality issues associated with uranium deposits in the West and East Coolers for the 6A Booster Station in Building K-31 at the Oak Ridge K-25 Site. This assessment investigates the applicability of the initial assumptions used by Lockheed Martin Energy Systems (Energy Systems) and evaluates criticality calculations previously completed by Energy Systems.

The calculations were independently verified. Each component was evaluated for its ability to satisfy requirements for subcriticality and meet the double contingency principle. Facility walk downs, detailed neutronics analysis, and fault tree analysis (FTA) were performed. The facility walk downs provided a better understanding of the building condition and status, equipment configuration, and uranium deposit locations. The detailed neutronics analysis focused on system geometry and moderation levels applicable to the individual components. The FTA considered the annual rate of occurrence for the events identified as potential causes of criticality issues. This report also examines the advantages of using this type of evaluation to assess the removal process for additional components and equipment.

\subsection{BACKGROUND}

The K-25 Site, previously known as the Oak Ridge Gaseous Diffusion Plant, supplied enriched uranium for nuclear weapons production as part of the Manhattan Project during World War II. Construction of the site started in 1943, and the first diffusion facility for large-scale separation of ${ }^{235} \mathrm{U}$ was fully operable by August 1945. The plant took natural $(0.711$ percent ${ }^{235} \mathrm{U}$ ) uranium as feed and processed it into low enriched uranium and highly enriched uranium with concentrations of approximately 93 percent ${ }^{235} U$ using the gaseous diffusion process. During operation, humid air leaking into process piping and equipment caused reactions with gaseous uranium hexafluoride $\left(\mathrm{UF}_{6}\right)$ that produced nonvolatile uranyl fluoride $\left(\mathrm{UO}_{2} \mathrm{~F}_{2}\right)$ deposits. The deposits are in a variety of locations, configurations and enrichments. They are also outside the original design basis for operation of the process system.

The K-25 Site produced enriched uranium until 1985. The decision to permanently shut down the gaseous diffusion cascade was made in December 1987. After shutdown, the volatile $\mathrm{UF}_{6}$ was evacuated. However, the $\mathrm{UO}_{2} \mathrm{~F}_{2}$ deposits remained. In the interest of safety, the U.S. 
Department of Energy (DOE) initiated a program to remove the large deposits of enriched uranium. This study investigates the safety of the deposits in the West and East Coolers for the $6 \mathrm{~A}$ Booster Station of Building K-31 as they exist today.

\subsection{CRITICALITY ISSUES}

The requirement to ensure nuclear criticality safety is found in American Nuclear Society (ANS)/American National Standards Institute, Inc. Standard 8.1 Section 4.1.2. This requirement is as follows:

\subsubsection{Process Analysis. Before a new operation with fissionable materials is begun or before an existing operation is changed, it shall be determined that the entire process will be subcritical under both normal and credible abnormal conditions. Care shall be exercised to determine those conditions which result in the maximum effective multiplication factor $\left(k_{\text {eff }}\right)$ (ANS 1988).}

The primary methodology recommended to satisfy the requirement for nuclear criticality safety is the double contingency principle. The principle states that:

\section{Process designs should, in general, incorporate sufficient factors of safety} to require at least two unlikely, independent, and concurrent changes in process conditions before a criticality accident is possible (ANS 1988).

DOE has modified this principle and incorporated it into DOE Order 5480.24, "Nuclear Criticality Safety," as a requirement. Because of some confusion over correct interpretation of this Order, DOE produced additional documentation. The interpretation document defines "a criticality accident" as a "credible criticality accident" (Goldenburg 1993). This approach ensures that no credible single failure or mishap will result in a criticality accident.

\subsection{DEPOSIT ISSUES}

Two issues surrounding the $\mathrm{UO}_{2} \mathrm{~F}_{2}$ deposits are discussed in this section. The first is the accuracy of the nondestructive assay (NDA) measurements. NDA measurements were not originally designed for detailed estimates of deposits and are, therefore, limited in their application. Section 1.4.1 describes general NDA methods and areas in which they are suspect. Individual component applications should be examined in detail. 
The other issue of major concern for the deposits is deliquescence. Section 1.4.2 describes the conditions under which the deposits may deliquesce. This area is also investigated on an individual component basis.

\subsubsection{NDA Measurement of Deposit}

NDA results for Building K-31 are described in detail in Energy Systems documents (Mayer and Cooley 1991). These NDAs were intended to identify the most significant uranium deposits in the facility. In general, the survey involved:

- gamma ray scanning of the entire facility to identify equipment that may contain uranium deposits of criticality concern,

- isotopic mapping of selected equipment in the facility to determine the average ${ }^{235} U$ assays, and

- quantitative neutron measurements of significant deposits to estimate their mass.

For deposits with estimated masses exceeding the limited safe mass (corresponding to the highest ${ }^{235} U$ assay material processed in the facility), further gamma ray measurements and/or quantitative neutron measurements were made to estimate the ${ }^{235} \mathrm{U}$ assay of the deposit. The limited safe mass is the operating limit for nuclear criticality safety. It varies with ${ }^{235} U$ assay and is always less than the minimum critical mass at the stated assay.

The majority of the estimates of deposit masses are within the uncertainties published in NDA reports. In general, measurement uncertainty in the mass and assay estimates are \pm 50 percent and \pm 20 percent, respectively. Unless otherwise noted, this evaluation uses +50 and +20 percent of the NDA measurements for the masses and assays, respectively. It is believed that the measurements accurately reflect the masses and assays (Hagenauer 1996). However, the actual mass uncertainties are difficult to quantify for some cases.

There have been instances when mass estimates have underestimated the actual mass by as much as a factor of three. These cases involved a number of unknown factors, which resulted in inaccurate measurements. The unknown factors included, but are not limited to, deposit location, deposit material, and surrounding materials. Equipment with unknown factors associated with the NDA measurements are noted in the detailed analysis. 


\subsubsection{Deliquescence}

The hygroscopic nature of the $\mathrm{UO}_{2} \mathrm{~F}_{2}$ deposit creates the potential for deliquescence. Under certain conditions, $\mathrm{UO}_{2} \mathrm{~F}_{2}$ can absorb enough water to create a solution. These conditions are typically not present in a sealed process system of a gaseous diffusion plant, but open systems may have these conditions. Therefore, individual cases should be evaluated to ensure the absence of conditions that might cause deliquescence. A summary of conditions believed to cause deliquescence follows.

A limited number of studies of deliquescence have been performed, the most recent by R. G. Russell in 1994. This study defined the parameters that control moisture levels of $\mathrm{UO}_{2} \mathrm{~F}_{2}$ in air with 50 percent and 100 percent relative humidities at temperatures ranging from ambient to approximately $93^{\circ} \mathrm{C}\left(200^{\circ} \mathrm{F}\right)$ (Russell 1994). This study used a finely divided powder produced in the laboratory.

The results of Russell's study showed that the deposits reach an equilibrium point of an hydration ratio $(H / U) \leq 4$ with room air (relative humidity of approximately 50-60 percent). Experiments involving a saturated atmosphere (approximately 100 percent relative humidity) with stagnant air showed no evidence of additional moisture gain in the $\mathrm{UO}_{2} \mathrm{~F}_{2}$ sample. It was concluded that the air did not flow enough to transfer water $\left(\mathrm{H}_{2} \mathrm{O}\right)$ to the samples. This observation lead to an additional experiment involving a large source of liquid water near a $\mathrm{UO}_{2} \mathrm{~F}_{2}$ sample. This experiment created a saturated atmosphere with good diffusion of water to the surface of the $\mathrm{UO}_{2} \mathrm{~F}_{2}$, causing the $\mathrm{UO}_{2} \mathrm{~F}_{2}$ to deliquesce. During the experiment, a "supersaturated atmosphere" was periodically observed.

Russell concluded that "in a saturated atmosphere with good circulation, the $\mathrm{UO}_{2} \mathrm{~F}_{2}$ will "... form a solution, but several hours [approximately 30 hours] is required" (Russell 1994). He also states that the "saturated conditions must be maintained for the material to continue to sorb moisture" (Russell 1994). As his experiments show, "in the event the relative humidity decreases, the solution will begin losing moisture back to the atmosphere." This indicates that a saturated atmosphere with good circulation must be maintained for 30 hours to cause deliquescence. Russell indicates that in an actual plant environment, the conditions necessary for deliquescence to occur are "difficult to imagine." A phone conversation with Russell indicated that the previous interpretations are consistent with the intent of his paper.

Russell's study does not include experimental data for humidity levels between 50 and 100 percent relative humidity. This range and other conditions that cause deliquescence are discussed in an unpublished draft, Uranyl Fluoride and Its Hydrates (Leitnaker et al. 1995), which 
concluded that a "key to preventing deliquescence is limitation of the partial pressure of the water vapor contacting the solid." Additionally Leitnaker et al. state that a key factor for limiting access of water vapor is the elimination of air flow. Further, "Russell's data indicate that the hydration does not exceed the nominal 2 moles of water per mole of $\mathrm{UO}_{2} \mathrm{~F}_{2}$ unless the partial pressure exceeds a minimum of 12 torr ( 50 percent relative humidity) at $25^{\circ} \mathrm{C}$ " (Leitnaker et al. 1995).

The actual behavior suggests that the partial pressure needed to caused deliquescence may be nearer 24 torr than 12 torr (Leitnaker et al. 1995). This conclusion was drawn because Russell observed deliquescence at a partial pressure of 24 torr (100 percent relative humidity) and good circulation.

Table 1 shows the correspondence between partial pressures, temperature, and relative humidity (Jordan 1996). A partial pressure of 24 torr for relative humidities lower than 100 percent occur at increased temperatures. Temperatures below $25^{\circ} \mathrm{C}\left(77^{\circ} \mathrm{F}\right)$ will not produce partial pressures of 24 torr regardless of the humidity. Relative humidities and temperatures corresponding to a partial pressure of 12 torr are also shown in the table; however, experimental data show deliquescence occurred only for 24 torr. Experiments with 12 torr did not cause deliquescence.

Table 1. Partial pressure of water in air

\begin{tabular}{|c|c|c|c|}
\hline \multirow{2}{*}{ 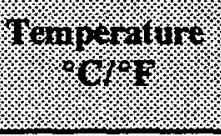 } & \multirow{2}{*}{ 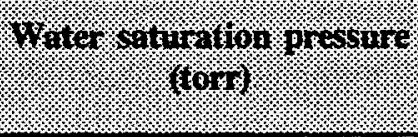 } & \multicolumn{2}{|c|}{ 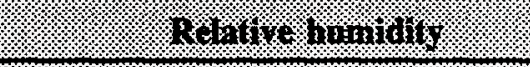 } \\
\hline & & 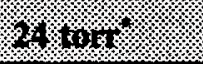 & $12 / 101.1$. \\
\hline $15(59)$ & 12.8 & - & $94 \%$ \\
\hline $20(68)$ & 17.5 & - & $68 \%$ \\
\hline $25(77)$ & 23.7 & $100 \%$ & $50 \%$ \\
\hline $30(86)$ & 31.8 & $75 \%$ & $38 \%$ \\
\hline $35(95)$ & 42.2 & $50 \%$ & $28 \%$ \\
\hline
\end{tabular}

Source: Jordan, W. C., ORNL. 1996. "Comments on Independent Evaluation of Criticality Issues Assaciated with Uranium Deposits at the K-25 Site, Oak Ridge, Tennessee," memorandum to T. L. Dahl, Sr., Energy Systems, Oak Ridge, TN.

Approximation.

${ }^{\circ} \mathrm{C}=$ degrees Celsius

${ }^{\circ} \mathrm{F}=$ degrees Fahrenheit

$$
\begin{aligned}
& \%=\text { percent } \\
& \text { torr }=\text { unit of pressure }
\end{aligned}
$$


Individual cases should be evaluated separately, and best engineering judgment should be made about the possibilities of deliquescence. Also, the neutronics effects caused by deliquescence should be investigated. Whenever possible, exposure to ambient air should be avoided or minimized.

In summary, the major conditions for deliquescence are the partial pressure of water in air (a function of humidity and temperature), good circulation, and time of exposure (at least 30 hours). High humidity and good circulation must occur simultaneously for a minimum of 30 uninterrupted hours before deliquescence is possible. If the humidity drops during this exposure time, the deposit will begin to dry out.

\section{ANALYSIS AND RESULTS}

\section{$2.1 \quad$ APPROACH}

Nuclear criticality issues at the K-25 Site were evaluated using Monte Carlo N-Particle Transport Code (MCNP) 4A on a Silicon Graphics, Inc., workstation. The cross sections used are the MCNP ENDF/B-V continuous energy set. The MCNP 4A software has been verified and validated on the workstation using the MCNP ENDF/B-V cross sections for a variety of sample problems and criticality experiments. Additional information about the verification and validation study can be found in an unpublished report by $R$. E. Pevey at the University of Tennessee at Knoxville (Pevey 1996).

The neutronics analysis of individual components uses a subcritical limit of 0.95 . This limit represents a safety margin because of biases in the cross sections and uncertainties in the models. Calculated values of $\mathrm{k}_{\text {eff }}+2 \sigma<0.95$ are considered safely subcritical. Values of $\mathrm{k}_{\text {eff }}+2 \sigma \geq 0.95$ are not considered safely subcritical.

Materials used in the models are input as number densities. Number densities are calculated using the method described by the MCNP manual (Briesmeister 1993). The deposits are modeled as $\mathrm{UO}_{2} \mathrm{~F}_{2} \cdot \mathrm{XH}_{2} \mathrm{O}$ (where $\mathrm{X}$ is the number of molecules of $\mathrm{H}_{2} \mathrm{O}$ ). Mass densities for uranium in compounds of $\mathrm{UO}_{2} \mathrm{~F}_{2}$ are calculated using equations found in Estimated Critical Condition for $\mathrm{UO}_{2} \mathrm{~F}_{2}-\mathrm{H}_{2} \mathrm{O}$ Systems in Fully Water Reflected Spherical Geometry for various $\mathrm{H} /{ }^{235} \mathrm{U}$ ratios (Jordan and Turner 1992). Number densities for all atoms in the deposit are calculated using the number density for uranium. Mass and enrichment of the deposits are taken from NDA measurements. Air is modeled as a void unless otherwise noted. All other material mass densities are taken from Perry's Chemical Engineering Handbook (Green and Maloney 1984). 
Based on the double contingency principle, only credible scenarios resulting in criticality issues were considered. Therefore, it was necessary to determine the credibility of scenarios resulting in potential criticality problems. FTA determined this credibility using the computer code CAFTA + . Any event with an annual probability of occurrence less than $10^{-6}$ is considered not credible.

\subsection{NEUTRONICS ANALYSIS}

The analysis initially reviewed the calculations performed by Oak Ridge National Laboratory (ORNL) personnel (Haire and Jordan 1996). ORNL calculated the development of minimum critical mass lines for $\mathrm{UO}_{2} \mathrm{~F}_{2}$ at $\mathrm{H} /{ }^{235} \mathrm{U}$ atomic ratios of 4 and 500 with at least $30.5 \mathrm{~cm}$ (12 in.) of water reflection. The review recalculated the minimum critical masses for enrichments less than 5 percent using a different code, MCNP 4A. The results of the review confirm ORNL's minimum critical mass lines for enrichments less than 5 percent.

An additional study was performed to determine the optimal moderation ratio. As the number of hydrogen atoms increases, reactivity increases up to a point; then reactivity drops. The highest reactivity is the optimal moderation ration. This study indicates that the optimal moderation is at an $\mathrm{H}^{235} \mathrm{U}$ ratio of 460 for enrichments less than 5 percent. The use of an $\mathrm{H} /{ }^{235} \mathrm{U}$ ratio of 500 is not exact but is sufficient for the initial study performed by ORNL. For all subsequent calculations presented here, an $H /^{235} U$ ratio of 460 is used as optimal moderation.

While the ORNL calculations are confirmed for enrichments less than 5 percent, the broad use of the minimum critical mass lines may be overly conservative for individual components. Generally, the optimally moderated and fully reflected cases are used for design considerations for functional equipment and may not be applicable in some shut-down equipment. To investigate the applicability of the assumptions for individual components, a more detailed analysis was performed.

\subsubsection{West Cooler for the 6A Booster Station in Building K-31}

The first component to be individually analyzed was the West Cooler for the 6A Booster Station. Knowledge of the structure and operation of the individual components is important in understanding the analysis. Following is a brief overview of the location, operation, structure, and deposit masses associated with the West Cooler.

Building K-31 contains a portion of the gaseous diffusion cascade. The building is constructed in two levels of steel columns and beams with transite siding, reinforced concrete 
floors, and a built-up roof of tar and gravel. The upper level [at elevation $239 \mathrm{~m}(784.5 \mathrm{ft})$ ] is the cell floor. The lower level [at elevation $232 \mathrm{~m}(762 \mathrm{ft})$ ] is the operation floor. The $6 \mathrm{~A}$ Booster Station and the West Cooler are located on the cell floor.

There are three process gas booster stations in Building K-31. The B-Stream Booster Station at the south end of Unit 1 increased process gas pressure of the depleted stream leaving Building K-31. The Evacuation Booster Station at the south end of Unit 3 removed process gas from the cascade in the event of an upset condition or maintenance. The A-Stream Booster Station at the south end of Unit 6 increased process gas pressure of the enriched stream from Unit 6 Cell 2 for transfer to Building K-29.

The West Cooler is one of two coolers of the 6A Booster Station that handled the enriched stream transferred to Building K-29. The West Cooler has an outside metal shell. The cooler was formed by using the ends of two diffusion units and a cylindrical midsection approximately $25.4 \mathrm{~cm}$ (10 in.) wide. Inside the cooler is a series of cooling tubes. During operations, Freon coolant was circulated through the tubes. There are 192 tubes in 12 rows of 16 each. Process gas entered one end of the cooler, was directed over the cooling tubes, then exited the other side (Fig. 1).

The process gases in the West Cooler were purged at shutdown with nitrogen gas and sealed. The inlet and outlet block valves are in the closed position, and air inleakage since shutdown has been minimal. Leaks may have occurred, but the system generally has had good integrity.

The deposit in the West Cooler formed due to air inleakage before shutdown and is assumed to be $\mathrm{UO}_{2} \mathrm{~F}_{2}$. According to NDA analysis, the West Cooler has a mass of 3,350 $\mathrm{g}$ of ${ }^{235} \mathrm{U}$ (Mayer and Cooley 1991). The deposit assay was estimated to be 2.75 percent enriched. This analysis used the upper limit for uncertainties (i.e., +50 percent for mass and +20 percent for assay). Using this factor, there are potentially $5,025 \mathrm{~g}$ of ${ }^{235} \mathrm{U}$ with an assay of 3.3 percent enrichment. The K-25 NDA Department also indicates a uniformly distributed deposit about the fin and tube region with a buildup of deposit in one section of the cooler. This observation is consistent with the manner in which deposits form on large surfaces.

The H/U of the deposits can be extrapolated from experimental data. Experimental data show that the deposits absorb moisture from the air to an equilibrium point of approximately $\mathrm{H} / \mathrm{U}=4$. After shutdown, the cooler was purged with nitrogen and sealed. While some air inleakage has occurred, the actual $\mathrm{H} / \mathrm{U}$ ratio is probably still less than 4. 


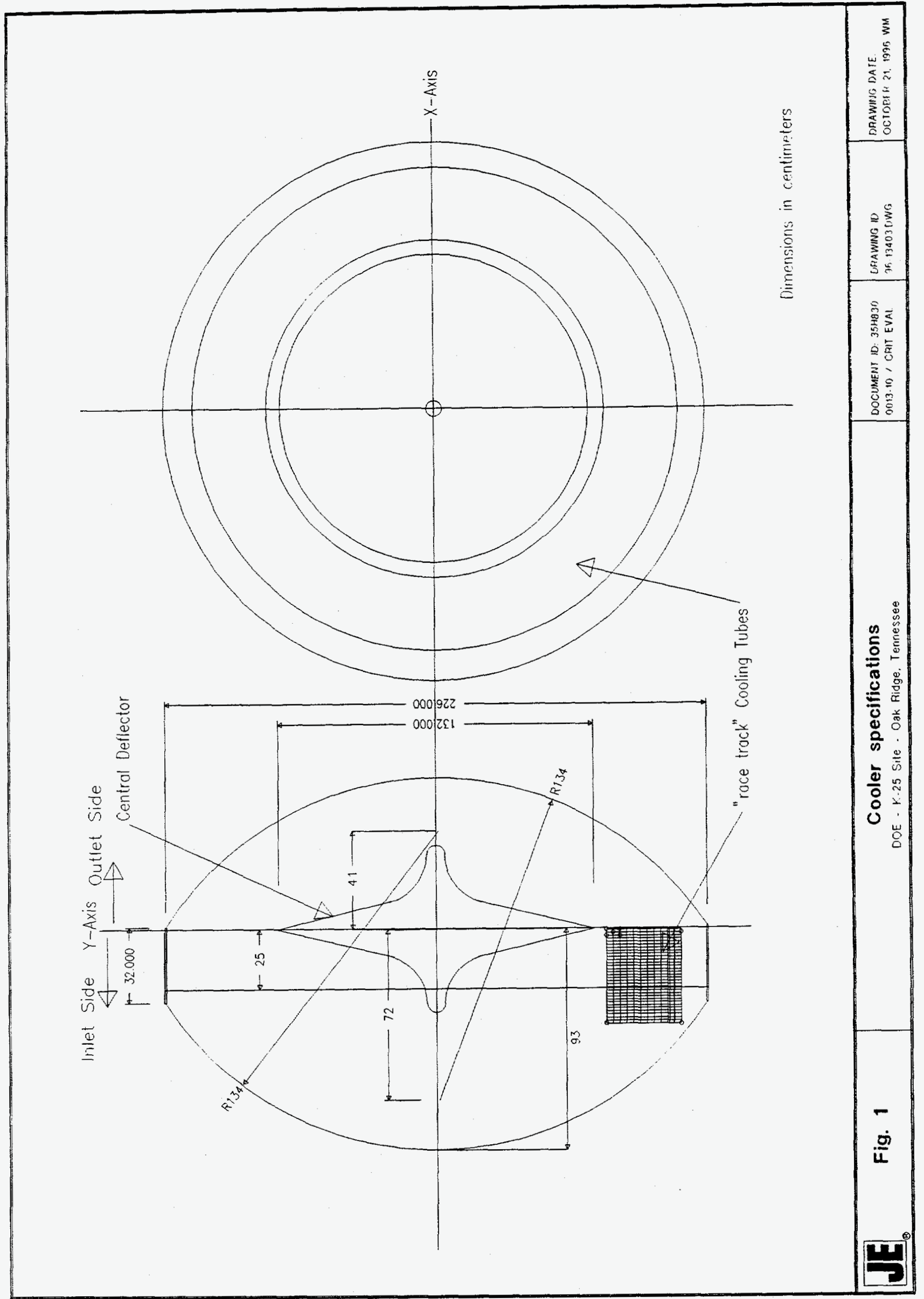




\subsubsection{Detailed analysis}

The detailed neutronic analysis using MCNP 4A investigates the present condition of the deposits and upset conditions. The use of MCNP 4A allows for a detailed model of the cooler internals ${ }^{1}$ with deposit locations and distributions. Copper and aluminum cooler materials were excluded from the model for conservatism. In models showing the deposits in direct contact with the aluminum, two results are presented-one without aluminum and one with a mixture of aluminum and deposit material.

Four deposit distributions are modeled. The first two are based on process knowledge and the NDA Department's observations, the third is based on possible gravity effect of the deposit, and fourth is based on spherical geometry. An $\mathrm{H} /{ }^{235} \mathrm{U}$ ratio of 150 was chosen for the model of the present conditions. This ratio correlates to an $\mathrm{H} / \mathrm{U} \cong 5.0$, which is conservative, based on technical engineering judgment.

The first distributions considered are based on a uniformly distributed deposit about the fin and tube region. A thin coating of deposit over the length of the coolant tubes is used in the model for this distribution. The coolant tubes are modeled as voids. Table 2 shows the calculated $\mathrm{k}_{\text {eff }}$ results for this distribution. Case 1 is the calculated value for this distribution with no water reflection. Case 2 shows the calculated value for this distribution with a $30.5-\mathrm{cm}$ (12-in.) water reflector added to the exterior of the cooler. The water reflector conservatively models a sprinkler activation or direct human contact with the exterior of the cooler. Two results for each case are presented. The first result is for the model that does not consider the aluminum fins. The second result is for the model in which the aluminum is mixed with the deposit

Table 2. Calculated $k_{\text {eff }}$ results for a uniform deposit distribution of $5,025 \mathrm{~g}$ of ${ }^{235} \mathrm{U}$ with present conditions $\left(H^{235} U=150\right)$ in the West Cooler of Building K-31, K-25 Site, Oak Ridge, Tennessee

\begin{tabular}{|c|c|c|c|}
\hline 6942,11 minser & 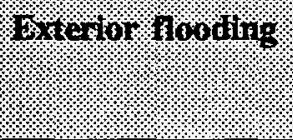 & 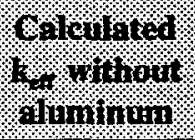 & Shrovinin \\
\hline 1 & No & 0.01 & 0.01 \\
\hline 2 & Yes & 0.23 & 0.23 \\
\hline
\end{tabular}

Note: One standard deviation $(1 \sigma)<0.003$ for all calculations.

$\mathrm{g}=\mathrm{gram}$

$\mathrm{H}=$ hydrogen

$k_{\text {eff }}=$ effective multiplication factor

$\mathrm{U}=$ uranium

'The internal structure of the " 0 " size cooler is taken from engineering drawings provided by Bob Ingram of Lockheed Martin Energy Systems. 
material at the proper volume fraction simulating aluminum fins. All calculated $\mathrm{k}_{\text {eff }}$ results presented in the table are below 0.95 and demonstrate subcriticality.

The NDA Department also observed buildup of deposit material in one section of the cooler around the coolant tubes. Therefore, a second case was developed. For conservatism, the entire mass was lumped in one section of the cooler. The calculated results for this distribution are shown in Table 3. As in the previous distribution, two cases, each with and without aluminum, are presented. The results are higher than those for the uniform distribution but are still well below 0.95 and demonstrate subcriticality for this distribution.

Gravity could cause the deposit to fall from its present location and collect in the bottom of the cooler. Therefore, an additional distribution simulating the potential result of such a movement has been studied. The model distribution fills the bottom of the cooler below a chord intersecting the cooler with the entire mass of deposit material. The results for the chord deposit distribution are presented in Table 4. Two cases are shown as before, but no aluminum is mixed into the deposit because the lower portion of the cooler contains no aluminum fins. The results are higher than previously but are still far subcritical (i.e., * 0.95 ).

The preceding distributions represent realistic deposit configurations. They are not the most reactive geometries. The most reactive geometry is spherical; however, the internal structure of the cooler does not allow for an unintersected sphere to form in the cooler. Also, the largest area that could accommodate a modified sphere (ellipsoid) is the void region on the exit side of the back defector. Gravity alone would not be sufficient to move the deposit into this

Table 3. Calculated $k_{\text {ef }}$ results for a lumped deposit distribution of $5,025 \mathrm{~g}$ of ${ }^{233} \mathrm{U}$ with present conditions $\left(H^{235} U=150\right)$ in the West Cooler of Building K-31, K-25 Site, Oak Ridge, Tennessee

\begin{tabular}{|c|c|c|c|}
\hline Gorminior & Grenlor gooding & Gringinining & 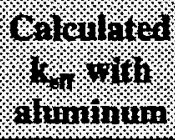 \\
\hline 1 & No & 0.17 & 0.15 \\
\hline 2 & Yes & 0.32 & 0.32 \\
\hline
\end{tabular}

Note: One standard deviation $(1 \sigma)<0.003$ for all calculations.

$\mathrm{g}=$ gram

$\mathrm{H}=$ hydrogen

$k_{\mathrm{efr}}=$ effective multiplication factor

$\mathrm{U}=$ uranium 
Table 4. Calculated $k_{\text {efr }}$ results for a chord deposit distribution of $5,025 \mathrm{~g}$ of ${ }^{235} \mathrm{U}$ with present conditions $\left(\mathrm{H}^{223} \mathrm{U}=150\right)$ in the West Cooler of Building K-31, K-25 Site, Oak Ridge, Tennessee

\begin{tabular}{|c|c|c|}
\hline 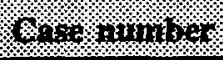 & 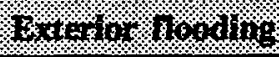 & Saloulyed \\
\hline 1 & No & 0.46 \\
\hline 2 & Yes & 0.68 \\
\hline
\end{tabular}

Note: One standard deviation $(1 \sigma)<0.003$ for all calculations.

$\mathrm{g}=$ gram

$\mathbf{H}=$ hydrogen

$k_{e f f}=$ effective multiplication factor

$\mathbf{U}=$ uranium

location or geometry. Also, no mechanism has been identified that would relocate the deposit in this manner.

Because this spherical configuration represents the most reactive geometry, a model for this distribution was studied. The model used an ellipsoidal mass of deposit positioned in the void space on the exit side of the back deflector. The results for the ellipsoidal distribution are shown in Table 5. The results do not reflect aluminum mixing, because no aluminum is present in this deposit location. As in the previous distributions, two cases are presented in the table. The values for $k_{\text {eff }}$ are below 0.95 , demonstrating subcriticality for the most reactive configuration. This distribution does not accurately represent the true configuration but is presented here to demonstrate the upper limit for $\mathrm{k}_{\text {eff }}$ of the deposit in its current state.

The previous results demonstrate subcriticality for all distributions, even with 150 percent of the mass estimate, 120 percent of the assay estimates, and a $30.5-\mathrm{cm}$ (12-in.) exterior water reflector. The unrealistic, yet conservative, ellipsoidal geometry yields the highest $k_{\text {eff }}(0.87)$ but is still subcritical. The conclusion is that the deposits are subcritical for the present conditions.

Table 5. Calculated $\mathbf{k}_{\mathrm{en}}$ results for an ellipsoidal deposit distribution of $5,025 \mathrm{~g}$ of ${ }^{235} \mathrm{U}$ with present conditions $\left(H^{23 s} U=150\right)$ in the West Cooler of Building K-31, K-25 Site, Oak Ridge, Tennessee

\begin{tabular}{|c|c|c|}
\hline Case numires & Mrterior $/$ rooding & 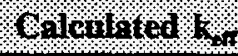 \\
\hline 1 & No & 0.83 \\
\hline 2 & Yes & 0.87 \\
\hline
\end{tabular}

Note: One standard deviation $(1 \sigma)<0.003$ for all calculations.

$\mathrm{g}=\mathrm{gram}$

$\mathrm{H}=$ hydrogen $\mathrm{k}_{\mathrm{eff}}=$ effective multiplication factor

$\mathbf{U}=$ uranium 
The following analysis investigates additional upset conditions in an effort to determine the controls that must be in place to prevent an inadvertent criticality. The upset conditions focus on water intrusion into the cooler. The probabilities of water ingress are discussed in Section 2.2.1.3 in detail. Upset conditions such as water ingress cause great changes to current conditions. The configuration of the deposits may not easily be described for cases that involve water flooding on the inside of the cooler. Flooding may involve many results. The deposits may keep their current position and hydrate until they are completely in solution, or the water may wash the deposits from their current position into some unknown position. For this reason, conservatism must be used for conditions in which water floods the cooler.

The analysis presented here investigates the potential transitions from the current state to the potentially most reactive state in an effort to identify the controls for ensuring subcriticality. This is done by presenting the previous distributions with four additional upset cases:

- The first upset case represents the conditions corresponding to potential moisture ingress that might cause the deposits to hydrate to an optimal moderation level $\left(\mathrm{H} / \mathrm{U}=15.2\right.$ or $\mathrm{H}^{235} \mathrm{U}=460$ for 3.3 percent enriched $)$.

- Case 2 adds $30.5 \mathrm{~cm}$ (12 in.) of exterior water reflection and the optimal moderation of Case 1.

- Case 3 represents full water flooding, causing the deposit to become optimally moderated $\left(\mathrm{H} / \mathrm{U}=15.2\right.$ or $\mathrm{H} /{ }^{235} \mathrm{U}=460$ for 3.3 percent enriched $)$ and surrounding the deposit with water reflection on the interior of the cooler.

- Case 4 combines Case 3 with an additional $30.5 \mathrm{~cm}$ (12 in.) of exterior water reflection.

Cases 1 and 2 address the neutronic effects of deliquescence (moisture absorption from air) without additional water flooding. Cases 3 and 4 represent complete flooding of the cooler with water. Optimal moderation $(H / U=15.2)$ will cause the deposit to have a slurry-like consistency, but at $\mathrm{H} / \mathrm{U}=16$, the deposit will be in a saturated solution. As the deposit absorbs more moisture, it will go into solution; $k_{\text {eff }}$ will go down because of over-moderation.

The $\mathrm{k}_{\text {eff }}$ results for upset conditions involving the uniform distribution are shown in Table 6. All cases are subcritical. This distribution would be representative of the actual distribution for Cases 1 and 2 because the deposit would have a slurry consistency and would not be prone to movement. As mentioned previously, once water has flooded the cooler (Cases 3 
Table 6. Calculated $k_{\text {eff }}$ results for a uniform deposit distribution of $5,025 \mathrm{~g}$ of ${ }^{235} \mathrm{U}$ with upset conditions $\left(H{ }^{235} U=460\right)$ in the West Cooler of Building K-31, K-25 Site,

Oak Ridge, Tennessee

\begin{tabular}{|c|c|c|c|c|}
\hline$\% 14 \%$ & interior 130 inting & 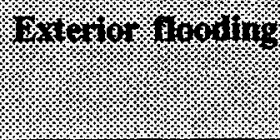 & (4) & Kantining \\
\hline 1 & No & No & 0.02 & 0.02 \\
\hline 2 & No & Yes & 0.28 & 0.30 \\
\hline 3 & Yes $^{a}$ & No & 0.52 & 0.55 \\
\hline 4 & Yes $^{a}$ & Yes & 0.52 & 0.55 \\
\hline
\end{tabular}

Note: One standard deviation $(1 \sigma)<0.003$ for all calculations.

Internal flooding may result in a higher $\mathrm{H}^{23} \mathrm{U}$ ratio.

$\mathrm{g}=\mathrm{gram}$

$\mathrm{H}=$ hydrogen

$k_{\text {en }}=$ effective multiplication factor

$\mathrm{U}=$ uranium

and 4), the geometry of the deposit may not be easily described and this distribution may not be applicable.

The calculated results for the lumped distribution under the upset conditions are shown in Table 7. For Cases 1 and 2 , the $\mathrm{k}_{\text {eff }}$ values are below 0.95 , indicating subcriticality for cases involving moisture absorption only. The $\mathrm{k}_{\text {eff }}$ values of Cases 3 and 4 are greater than 0.95 . This

Table 7. Calculated $k_{\text {eff }}$ results for a lumped deposit distribution of $5,025 \mathrm{~g}$ of ${ }^{235} \mathrm{U}$ with upset conditions $\left(\mathrm{H}^{235} \mathrm{U}=\mathbf{4 6 0}\right)$ in the West Cooler of Building K-31, K-25 Site,

Oak Ridge, Tennessee

\begin{tabular}{|c|c|c|c|c|}
\hline $29.510 \%$ & timerior liogoling & 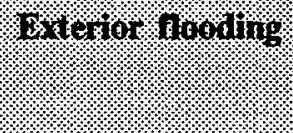 & (6) & Gilloritited \\
\hline 1 & No & No & 0.63 & 0.82 \\
\hline 2 & No & Yes & 0.68 & 0.85 \\
\hline 3 & $\mathrm{Yes}^{a}$ & No & 0.98 & 0.96 \\
\hline 4 & $\mathrm{Yes}^{a}$ & Yes & 0.98 & 0.96 \\
\hline
\end{tabular}

Note: One standard deviation $(1 \sigma) \leq 0.003$ for all calculations.

Internal flooding may result in a higher $\mathrm{H}^{235} \mathrm{U}$ ratio.

$\mathrm{g}=\mathrm{gram}$

$\mathrm{H}=$ hydrogen

$k_{\text {efr }}=$ effective multiplication factor

$\mathbf{U}=$ uranium 
indicates a potential criticality problem for events involving interior water flooding. The results for this distribution show the importance of excluding water flooding and that moisture absorption (deliquescence) alone will not lead to a criticality for this distribution.

Table 8 shows the results for the chord distribution under upset conditions. The calculated values of $k_{\text {eff }}$ are below 0.95 for Cases 1 and 2 . Therefore, for events involving only moisture absorption, the deposits are subcritical for this distribution. However, for cases involving interior water flooding (Cases 3 and 4), the values of $k_{\text {eff }}$ are greater than 0.95 indicating a potential criticality. This distribution also shows the importance of precluding water flooding of the cooler interior.

The upset conditions modeled for the ellipsoidal distribution yielded the results in Table 9. All results are above 0.95 . This indicates a potential criticality for cases involving moisture ingress and a conservative geometry. No mechanism for the formation of this geometry has been identified. However, full water flooding could drastically move the deposit; this geometry should be considered situations involving full water flooding. Moisture absorption alone would not move and shape the deposit into an ellipse.

The results for the upset conditions show that water flooding the interior of the cooler has potential for causing a criticality. The results also show that deliquescence alone will not cause a criticality. In order to have a criticality, deposits must have optimal moderation and either have sufficient water on the interior of the cooler to create refection or form an optimized geometry. The latter would require more than hydration to occur and is not considered to be achievable.

Table 8. Calculated $k_{\text {eff }}$ results for a chord deposit distribution of $5,025 \mathrm{~g}$ of ${ }^{235} \mathrm{U}$ with upset conditions $\left(H^{235} U=460\right)$ in the West Cooler of Building K-31, K-25 Site, Oak Ridge, Tennessee

\begin{tabular}{|c|c|c|c|}
\hline Cascronaber: & Iriterior Hooding & Grterior fooding & Carculated (1) \\
\hline 1 & No & No & 0.78 \\
\hline 2 & No & Yes & 0.88 \\
\hline 3 & Yes & No & 0.96 \\
\hline 4 & Yes & Yes & 0.97 \\
\hline
\end{tabular}

Note: One standard deviation $(1 \sigma)<0.003$ for all calculations.

$\mathbf{g}=\mathbf{g r a m}$

$\mathrm{H}=$ hydrogen $k_{\text {eff }}=$ effective multiplication factor

$\mathrm{U}=$ uranium 
Table 9. Calculated $k_{\text {eff }}$ results for an ellipsoidal deposit distribution of $5,025 \mathrm{~g}$ of ${ }^{235} \mathrm{U}$ with upset conditions $\left(\mathrm{H}^{235} \mathrm{U}=460\right)$ in the West Cooler of Building K-31, K-25 Site,

Oak Ridge, Tennessee

\begin{tabular}{|c|c|c|c|}
\hline rovolinn, & 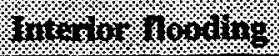 & 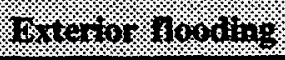 & 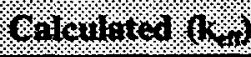 \\
\hline 1 & No & No & 1.00 \\
\hline 2 & No & Yes & 1.02 \\
\hline 3 & Yes & No & 1.05 \\
\hline 4 & Yes & Yes & 1.07 \\
\hline
\end{tabular}

Note: One standard deviation $(1 \sigma)<0.003$ for all calculations.

$\mathrm{g}=\mathrm{gram}$

$\mathrm{H}=$ hydrogen

$k_{e f f}=$ effective multiplication factor

$\mathrm{U}=$ uranium

The conclusion is that a criticality will not occur unless water is allowed to flood the interior of the cooler.

\subsubsection{Deposit deliquescence}

Deliquescence of the deposit in the West Cooler does not cause criticality concerns; however, additional discussion follows.

The condition of the West Cooler is such that significant ambient air inleakage is not anticipated. Additionally, a nitrogen buffer was in place at the time of shutdown (1987). As the deposit is maintained, the conditions required for deliquescence of the deposit are not available. Exposure of the deposit to deliquescence conditions requires severe changes in the present state of the West Cooler. The severe changes must cause good circulation of humid air over the deposit surface for deliquescence to be possible. Good circulation requires removal of a significant area of the West Cooler shell. Equipment collisions would, at worst, cause punctures in the shell and not remove enough area of the shell to create good circulation. Additionally, the circulation of humid air would have to be maintained for a minimum of 30 hours before the deposit will deliquesce. No credible accident mechanism has been identified that would cause removal of enough cooler shell area to create the circulation needed for deliquescence to occur.

Due to the configuration of the West Cooler and the administrative controls over access to the cell floor, the severe changes necessary to cause deliquescence are not considered plausible. This conclusion is also shared with R. Kirchner, who stated that neither deliquescence nor condensation are credible sources of water for moderation of the deposit (Kirchner and Emmet 1993). The conclusion is that deliquescence will not occur in the West Cooler. 


\subsubsection{Water ingress}

The neutronic calculations show that flooding the interior of the West Cooler with water is required before a criticality is possible. This section discusses the likelihood of failures that would lead to water ingress to the cooler.

Experienced operators and engineers at the K-25 Site consider water ingress into the West Cooler of Building K-31 to be unlikely, if not impossible (Latham 1996; Dyer 1996). A thorough walk down of the system shows that a failure in the system catastrophic enough to cause water ingress is not credible. This conclusion was based on the system's configuration, lack of worker activity around the cooler, and the number of simultaneous failures required before a pathway and source of water for ingress could exist. Based on this conclusion, the West Cooler in Building K-31, as it is presently maintained, satisfies both the subcritical requirement in ANS 8.1, Section 4.1.2, and the double contingency principle of ANS 8.1, Section 4.2.2.

An FTA was also performed to quantify the probability of the failure to prevent water ingress to the cooler. The fault tree focuses on natural phenomena as the initiating event that could lead to water ingress. Administrative control and human errors were not considered because they would not significantly contribute to the failure to prevent water ingress. Administrative controls are assumed to be in place to prevent human error from leading directly to water ingress. This assumption is valid due to the shutdown state of the cooler and support systems and the requirement for a radiation work permit before any work can begin near the cooler.

The fault tree is shown in detail in Appendix A. The top event for the fault tree is the failure to prevent water ingress to the cooler. This failure would allow moderation of the deposit. A schematic of the system is also presented in Appendix A.

Four possible areas were identified that would allow water ingress to the cooler:

- Through the process piping that led directly to the cooler and the deposit. There were five paths through the process piping where water could potentially reach the deposit.

- Through a breach in the cooler and room flooding due to dam failures.

- Through the Freon condenser and cooler tubes. 
- Into the process piping as a result of breaches caused by natural phenomena. Natural phenomena considered during fault tree development include external floods (from dam failures), tornados, and seismic events.

No credible flood accident scenario will result in a criticality in Building K-31 (Kirchner and Emmet 1993). The failure of Norris Dam concurrent with one-half the probable maximum flood is an not credible event. Therefore, the fault tree did not include any events related to external flooding. The neutronics calculations included external flooding as a worst-case scenario for completeness.

Tornado-generated missiles can rupture the expansion joints, opening a path for water to enter the cooler. The analysis assumes, conservatively, that the tornado strike frequency equates to the frequency of a missile rupturing the process piping expansion joints. Water, as a result of the tornado, would be available for ingress to the deposit. Also, for the five identified paths to the deposit, water would have to pass through at least one normally closed block valve.

At lower seismic levels, only the process piping expansion joints are subject to failure (Energy Systems 1992). Water from a roof leak or from an independent failure of the fire protection system must enter the process piping at the broken expansion joint. For the five identified paths to the deposit, water would have to pass through at least one normally closed block valve.

The fault tree includes the failure of the fire protection sprinkle system, which could deluge the cooler.

A fire could also activate the fire protection system. In this case, the only failure necessary to potentially deluge the cooler would be the fire itself. For these fires to occur, an ignition source and combustible material must come together. Compressor lube oil was the only large inventory of combustible material in Building K-31. This lube oil was drained to storage tanks and then removed from the building completely. Based on walk downs of the booster station, there is no other combustible material in the area. Consequently, a fire in the booster station area could not occur, and the sprinkler system would not be activated. Therefore, the fault tree did not include any cooler flooding or deluging from sprinkler activation due to a fire.

Based on the above discussion and the details given in Appendix A, the FTA results show that the probability (or annual frequency) of the failure to prevent water ingress to the cooler is between $10^{-9}$ and $10^{-8}$. These results agree with conclusions of the system walk down with operations personnel that any water ingress to the cooler is not a credible event. 


\subsubsection{East Cooler for the 6A Booster Station in Building K-31}

The East Cooler's position, structure, and operation are similar to those of the West Cooler. The East Cooler is on the cell floor [at elevation $239 \mathrm{~m}(784.5 \mathrm{ft})$ ] and is a duplicate of the West Cooler. The East Cooler was used in conjunction with the West Cooler to handle the enriched stream transferred from Building K-29.

Air inleakage before shutdown formed the deposit in the East Cooler, which is assumed to be $\mathrm{UO}_{2} \mathrm{~F}_{2}$. NDA measurements for the East Cooler indicate a mass of $1,776 \mathrm{~g}$ of ${ }^{235} \mathrm{U}$ (Mayer and Cooley 1991). The assay of the material was estimated to be 3.51 percent enriched. Using the upper limits of the uncertainties, the mass and assay used for analysis were $2,664 \mathrm{~g}$ of ${ }^{235} \mathrm{U}$ and 4.21 percent enrichment, respectively. The NDA Department indicated that the majority of the deposit mass is on the bottom of the cooler.

The deposit environment is the same as in the West Cooler; therefore, the hydration level is assumed to be an $\mathrm{H} / \mathrm{U}=4$.

\subsubsection{Detailed analysis}

The detailed analysis for the East and West Coolers follows the same general format. To avoid duplication, many similar details are not repeated here.

The same MCNP 4A model for the structure of the cooler is used because both coolers have the same design. The differences in the models are the mass of deposit and the distribution of the deposits. For the East Cooler, a deposit mass of $2,664 \mathrm{~g}$ at 4.21 percent enrichment is used. Only two distributions are modeled. The first is based on NDA measurements, which indicated that the majority of the deposit is near the bottom of the cooler. The other distribution is based on a spherical geometry. Neither distribution involved intersection with the aluminum fins, therefore the aluminum was not modeled. An $\mathrm{H} /{ }^{235} \mathrm{U}=150$ ratio is used for the present conditions, which correlates to a conservative $H / U \cong 6.3$.

The first distribution is modeled by positioning the entire mass of the deposit in the volume below a chord intersecting the lower portion of the cooler (chord distribution). The results of the chord distribution with an $\mathrm{H} /{ }^{235} \mathrm{U}=150$ are shown in Table 10. All the results are well below 0.95 and demonstrate subcriticality for this distribution in the East Cooler.

As with the West Cooler, the spherical distribution was modified to an ellipsoid so the deposit mass could be positioned in the cooler. Presentation of this distribution is offered as an upper limit and not to give credence to the formation of this distribution. Table 11 shows the 
Table 10. Calculated $k_{\text {eff }}$ results for a chord deposit distribution of $2,664 \mathrm{~g}$ of ${ }^{235} \mathrm{U}$ with present conditions $\left.(H)^{235} U=150\right)$ in the East Cooler of Building $K-31, K-25$ Site,

Oak Ridge, Tennessee

\begin{tabular}{|c|c|c|}
\hline 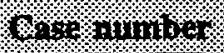 & 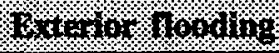 & 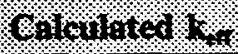 \\
\hline 1 & No & 0.36 \\
\hline 2 & Yes & 0.57 \\
\hline
\end{tabular}

Note: One standard deviation $(1 \sigma)<0.003$ for all calculations.

$\mathrm{g}=\mathrm{gram}$

$\mathrm{H}=$ hydrogen

$k_{\text {en }}=$ effective multiplication factor

$\mathrm{U}=$ uranium

results for the ellipsoid distribution. Even with the ellipsoidal geometry, the results are below the subcritical limit. This demonstrates that even the upper limit, regardless of probability of occurrence, is subcritical for the current conditions.

The previous results demonstrate subcriticality for the two distributions, even with 150 percent of the mass estimate, 120 percent of the assay estimates, and a $30.5-\mathrm{cm}$ (12-in.) exterior water reflector. The unrealistic, yet conservative, ellipsoidal geometry yields the highest $k_{\text {eff }}$ (0.76) but is still subcritical. The conclusion is that the deposits are subcritical for the present conditions.

As with the West Cooler, additional upset conditions are modeled to determine the controls that must be in place to prevent an inadvertent criticality. The same four upset cases are used with each cooler and involve various levels of water flooding:

- The first upset case uses an optimally moderated deposit $(\mathrm{H} / \mathrm{U}=16.95$ or $\mathrm{H} /{ }^{235} \mathrm{U}=460$ for 4.21 percent enriched) with no water reflection.

Table 11. Calculated $k_{\text {ef }}$ results for an ellipsoidal deposit distribution of $2,664 \mathrm{~g}$ of ${ }^{235} \mathrm{U}$ with present conditions $\left(H^{235} U=150\right)$ in the East Cooler of Building K-31, K-25 Site,

Oak Ridge, Tennessee

\begin{tabular}{|c|c|c|}
\hline Casegnumber & Arterion fooding & Salonlated Kat \\
\hline 1 & No & 0.73 \\
\hline 2 & Yes & 0.76 \\
\hline
\end{tabular}

Note: One standard deviation $(1 \sigma)<0.003$ for all calculations.

$\mathrm{g}=$ gram

$\mathrm{H}=$ hydrogen

$k_{\mathrm{er}}=$ effective multiplication factor

$\mathrm{U}=$ uranium 
- Case 2 has $30.5 \mathrm{~cm}$ (12 in.) of exterior water reflection added to the optimal moderation of Case 1.

- Case 3 has full interior flooding in which the deposit reaches optimal moderation and has additional water reflection caused by the interior flooding.

- Case 4 adds $30.5 \mathrm{~cm}$ (12 in.) of exterior water reflection to the full interior water flooding in Case 3.

For the East Cooler deposit, the deposit will be in a saturated solution at optimal moderation $(\mathrm{H} / \mathrm{U}=16.95)$. The two previous distributions are used in conjunction with the four upset conditions. The only difference will be an increase in the volume of deposit due to the optimal moderation.

The chord distribution accurately represents the distribution of the deposit when it becomes optimally moderated (solution) in Cases 1 and 2. For the cases involving full interior flooding (Cases 3 and 4), the chord distribution will represent a snapshot in time, before the deposit hydrates further, causing $\mathrm{k}_{\mathrm{eff}}$ to decrease. The results for the chord distribution for the upset conditions are shown in Table 12. All of the results in the table are below 0.95 and demonstrate subcriticality for the chord distribution in the East Cooler under the upset conditions. The results for Cases 1 and 2 show that deliquescence alone will not cause a criticality. During Cases 3 and 4 , however, the water flooding the interior of the cooler may temporarily move the deposit; an upper limit geometry should be used for these cases.

Table 12. Calculated $k_{\text {en }}$ results for a chord deposit distribution of $2,664 \mathrm{~g}$ of ${ }^{235} \mathrm{U}$ with upset conditions $\left(H^{233} U=460\right)$ in the East Cooler of Building K-31, K-25 Site, Oak Ridge, Tennessee

\begin{tabular}{|c|c|c|c|}
\hline Qenserinimer & Hite ror frooding & 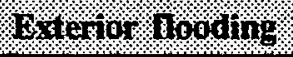 & 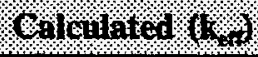 \\
\hline 1 & No & No & 0.63 \\
\hline 2 & No & Yes & 0.76 \\
\hline 3 & Yes & No & 0.79 \\
\hline 4 & Yes & Yes & 0.89 \\
\hline
\end{tabular}

Note: One standard deviation $(1 \sigma)<0.003$ for all calculations.

$\mathrm{g}=$ gram

$H=$ hydrogen $k_{e f f}=$ effective multiplication factor

$\mathrm{U}=$ uranium 
As before, the ellipsoid distribution is presented as an upper limit and not to give credibility to its formation. During extreme upset conditions, such as interior flooding, the distribution of the deposit may be difficult to describe; the upper limit distribution is presented to illustrate the highest potential $k_{\text {eff }}$. The results for this distribution are presented in Table 13 . The calculated $k_{\text {eff }}$ for Case 1 is below 0.95 and shows that, regardless of geometry, optimal moderation (i.e., deliquescence) of the East Cooler deposit will not cause a criticality. The result for Case 2 is 0.958 and is above the subcritical limit, indicating that, for these conditions, the deposit may not be safely subcritical. The Case 3 result is 0.99 and also above the subcritical limit, but still below 1.0. This result shows that the conditions present in Case 3 may not be safely subcritical. The conditions present in Case 4 result in a calculated $k_{\text {eff }}=1.03$. This suggests that a criticality may occur if the deposit forms an ellipse and the upset conditions in Case 4 are satisfied.

The previous results show that the deposit in the East Cooler is safely subcritical as currently maintained. Because the deposit is subcritical for cases involving only optimal moderation, deliquescence alone will not cause a criticality. In addition, the results indicate that the deposit must form an optimally moderated ellipse and have either exterior or interior water flooding before the calculated $k_{\text {eff }}$ values exceed 0.95 . The only result that exceeds 1.0 is one involving an optimally moderated ellipse with both interior and exterior flooding with water.

\subsubsection{Deposit deliquescence}

The discussion of deliquescence for the East Cooler is the same as for the West Cooler (see Sect. 2.2.1.2). As in the West Cooler, deliquescence will not occur because the air circulation required will not be available. This is true for all identifiable upset conditions.

Table 13. Calculated $\mathrm{k}_{\mathrm{en}}$ results for an ellipsoidal deposit distribution of $2,664 \mathrm{~g}$ of ${ }^{235} \mathrm{U}$ with upset conditions $\left(\mathrm{H}^{235} \mathrm{U}=\mathbf{4 6 0}\right)$ in the East Cooler of Building K-31, K-25 Site,

Oak Ridge, Tennessee

\begin{tabular}{|c|c|c|c|}
\hline Casc nominer & mineror hooding & 6rover 1 rooding & 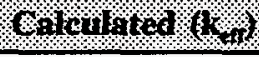 \\
\hline 1 & No & No & 0.925 \\
\hline 2 & No & Yes & 0.958 \\
\hline 3 & Yes & No & 0.99 \\
\hline 4 & Yes & Yes & 1.03 \\
\hline
\end{tabular}

Note: One standard deviation $(1 \sigma)<0.003$ for all calculations.

$\mathrm{g}=\mathrm{gram}$

$\mathrm{H}=$ hydrogen $\mathbf{k}_{\mathrm{eft}}=$ effective multiplication factor

$\mathrm{U}=$ uranium 
The results show that deliquescence alone will not lead to conditions that make a criticality possible. An inadvertent criticality in the East Cooler will require at least liquid water intrusion into the cooler. This intrusion would also have to cause the formation of an unfavorable geometry (ellipsoid).

\subsubsection{Water ingress}

Water ingress to the cooler is required for a criticality to be possible in the East Cooler. Experienced operators and engineers at the K-25 Site conclude that water ingress is unlikely, if not impossible.

The FTA performed for the West Cooler can be applied to the East Cooler because the coolers and configuration are the same. Therefore, the East Cooler has the same probability of annual occurrence, which is between $10^{-9}$ and $10^{-8}$. This supports the process knowledge and engineering conclusion that water ingress is not credible for the East Cooler in Building K-31.

Due to neutronic calculations and the conclusion that water ingress is not credible, the East Cooler in Building K-31, as it is presently maintained, satisfies both the subcritical requirement in ANS 8.1, Section 4.1.2, and the double contingency principle of ANS 8.1, Section 4.2.2.

\section{CONCLUSIONS}

The detailed analyses for the West and East Coolers show that the deposits are safely subcritical ( $k_{\text {eff }}+2 \sigma<0.95$ ) in the current state. For upset conditions, deliquescence of the deposit alone will not cause a criticality; water ingress to the cooler is required before a nuclear criticality is possible. Based on the process knowledge of experienced operators and engineers, water ingress to the two coolers studied is not credible. An FTA quantified the conclusions of the operators and engineers by calculating an estimate of the annual probability of occurrence. The estimate (between $10^{-9}$ and $10^{-8}$ ) supports the conclusion that water ingress is not credible. Because a credible mechanism for criticality has not been identified, the West and East Coolers satisfy the requirement for subcriticality (ANS 8.1, Sect. 4.1.2) and the double contingency principle (ANS 8.1, Sect. 4.2.2) as presently maintained. Satisfying the double contingency principle means that no single failure would result in a credible criticality accident.

Given the same conditions associated with the minimum critical mass curves developed by ORNL, the results agree. However, all assumptions should be evaluated for applicability to individual components. In the case of the West and East Coolers, the assumptions of spherical 
geometry, optimal moderation, and $30.5 \mathrm{~cm}(12 \mathrm{in}$.$) of water reflection are not credible$ scenarios.

This study is valid if the cooler is maintained so that system integrity precludes water ingress. Administrative controls must ensure that changes in current conditions will not increase the chance of water ingress. Generally, action impacting the coolers should be reviewed to determine the applicability of this study for those actions.

\section{RECOMMENDATIONS}

The deposits in the coolers must be maintained in their current state for the assumptions of this analysis to be valid. Therefore, it is recommended that the West and East Coolers be maintained in their current state. If future site plans impact the current state of the coolers, then additional analysis may be necessary to ensure that the probability of water ingress is not increased.

It is also recommended that the methodology presented (neutronics calculations coupled with system analysis) be used to analyze other deposits and equipment to ascertain in situ safety. This methodology should be extended to cover future work and activities with or near deposits of concern, including deposit removal. The results of this methodology should be used to help prioritize the deposit removal program. The results can also be used to remove deposits of little to no concern from the removal list. Prioritizing the removal process should not be based solely on mass, but should also take into account in situ safety and changes necessary for a criticality event to occur.

When using this methodology, "it cannot be overemphasized that personnel with experience in past operations, both routine and clean-out, and aided by professionals with knowledge of the chemistry and metallurgy of the fissile bearing material must be the source of the best professional judgments as to actual conditions present" (McLaughlin 1996).

Improvements to the methodology can be gained through better quantification of the deposit chemistry and locations. This can be achieved through physical investigation of the deposits during the deposit removal or through the use of fiber optics with the deposits in situ. Chemical analysis could also improve the quantification of the NDA uncertainties, which would be very useful for future analysis. As appropriate, each deposit removal should be documented and studied for lessons learned to aid in subsequent removal efforts. 


\section{MEETING PROGRAM OBJECTIVES}

The objective of the Deposit Removal Project is to bring the K-25 Site into compliance with DOE Order 5480.24, "Nuclear Criticality Safety." This chapter examines in detail the advantages of using the recommended approach for additional components in meeting this objective. The benefits of this method are safety and cost control.

The systematic engineering approach begins with prioritizing components. Prioritization may or may not include a detailed analysis, such as the one presented for the East and West Coolers, but should include the best engineering judgment. Prioritization should not rely on mass measurements alone. Instead, analysis and/or engineering judgment should be used to determine the components that are unsafe in situ and those that are safe. After categorizing the components, a decision must be made about the unsafe components. These components should either be removed immediately or isolated from personnel. Isolation may offer some cost benefits, but safety must be the prime consideration.

For components deemed safe in situ, an additional prioritization should be performed. This prioritization should compare the relative safety of the components through an investigation of the unknowns for each component. This comparison should indicate the component is the safest to remove, using best engineering judgment. Once the prioritization of these components is complete, then removal of the safest component can begin, while the other components are maintained in their safe state. By starting with the safest component, fewer random variables will be involved and safety can be better ensured. Removal of this component will either discredit or validate a number of assumptions. This knowledge can be used to reduce the number of unknowns in the next component. It may be best to group components in such categories as type of component or type of process.

The following example is presented for clarification and understanding. The East and West Coolers are similar in structure and share the same process line. Therefore, they share similar unknowns. Also, the West Cooler has more deposit mass than the East Cooler and appears to be the greater criticality concern. After the initial analysis, it is clear that both coolers are safe as they are presently maintained. However, future plans may require removal of the coolers. This removal process should begin with prioritizing the coolers. A review of the analysis for the West Cooler shows that the cooler could have criticality concerns if deposits become optimally hydrated and collect in an unfavorable geometry, both of which are difficult to control in a removal process. In this case, knowledge of the actual hydration level could be useful. Review of the analysis for the East Cooler reveals that the deposits are subcritical, 
regardless of hydration, provided water flooding is precluded. Water flooding may be easier to control than the factors associated with the West Cooler. Therefore, it is safer to deal with the East Cooler first. After removal of the East Cooler, deposit hydration levels can be checked and that information can be applied to the West Cooler. If, for example, the deposits are optimally hydrated, then additional analysis may be needed to ensure geometry control for the West Cooler. If the hydration is minimal, then expensive measures may be eliminated.

\section{REFERENCES}

ANS (American Nuclear Society). 1988. "Nuclear Criticality Safety in Operation with Fissionable Material Outside Reactors," Standard ANSI/ANS-8.1-1988. Washington, DC.

Breismeister, J. F., ed. November 1993. MCNP - A General Monte Carlo N-Particle Transport Code, Version 4A, UC 705 and UC 700. Los Alamos National Laboratory (LANL), Los Alamos, NM.

Dyer, R. Analysas Corp. April 16, 1996. Personal communication to D. L. Reed, Jacobs Environmental Restoration (ER) Team. Oak Ridge, TN.

Energy Systems (Martin Marietta Energy Systems, Inc.). 1992. Phase I Hazard Screening Analysis for $K-31$ Process Building. Oak Ridge, TN.

Green, D. W., and J. O. Maloney, eds. 1984. Perry's Chemical Engineer's Handbook, 6th ed. McGraw Hill, Inc., New York City, NY.

Goldenburg, N. 1993. Interpretive Guidance for DOE Order 5480.24, "Nuclear Criticality Safety." U.S. Department of Energy, Washington, DC.

Hagenauer, R., Energy Systems. 1996. Personal communication to L. S. Paschal, Jacobs ER Team. Oak Ridge, TN.

Haire, M. J., and W. C. Jordan. 1996. Relative Risk of Nuclear Criticality Occurring from LEU and HEU Deposits at the K-25 Site, Oak Ridge, Tennessee, K/ER-215. Oak Ridge, TN. 
Jordan, W. C., ORNL. 1996. "Comments on Independent Evaluation of Criticality Issues Associated with Uranium Deposits at the K-25 Site, Oak Ridge, Tennessee," memorandum to T. L. Dahl, Sr., Energy Systems, Oak Ridge, TN.

Jordan, W. C., and J. C. Turner. 1992. Estimated Critical Conditions For $\mathrm{UO}_{2} \mathrm{~F}_{2}-\mathrm{H}_{2} \mathrm{O}$ Systems in Fully Water Reflected Spherical Geometry, ORNL/TM12292. Martin Marietta Energy Systems, Inc., Oak Ridge National Laboratory, Oak Ridge, TN.

Kirchner, J. R., and R. W. Emmet. 1993. Preliminary Probabilistic Criticality Assessment of Selected Low-Enriched Uranium Facilities at the Oak Ridge K-25 Site, K/D-6048. Oak Ridge, TN.

Latham, B., Energy Systems. May 17, 1996. Personal communication to D. L. Reed, Jacobs ER Team. Oak Ridge, TN.

Leitnaker, J. M., R. G. Russell, and E. J. Barber. 1995. Uranyl Fluoride and Its Hydrates, unpublished draft. Martin Marietta Utility Services, Inc., Oak Ridge, TN.

Mayer, R. L., II, and J. N. Cooley. 1991. Nondestructive Assay Survey of Building K-31 Summary Report, ESP91-263. Oak Ridge, TN.

McLaughlin, T. P., LANL, Los Alamos, NM. 1996. Memorandum to Dennis Morgan, Jacobs ER Team, Oak Ridge, TN.

Pevey, R. E. 1996. Verification and Validation of MCNP on Honeck Workstation, unpublished. University of Tennessee at Knoxville, Knoxville, TN.

Russell, R. G. 1994. Investigation of Hygroscopic Properties of Uranyl Fluoride, KY/L-1699. Martin Marietta Utility Services, Inc., Oak Ridge, TN.

Russell, R. G. September 12, 1996. Personal communication to L. S. Paschal, Jacobs ER Team, Oak Ridge, TN. 
APPENDIX A

FAULT TREE ANALYSIS 


\section{FAULT TREE ANALYSIS}

Fault tree analysis is a technique of reliability engineering and safety analysis of complex systems. Four basic steps are employed by the technique:

- System definition

- Fault tree construction

- Qualitative evaluation

- Quantitative evaluation

\subsection{SYSTEM DEFINITION}

System definition includes determining the bounds of the system, defining the top event of interest, and establishing initial conditions. The system boundary for the Building K-31 booster station West and East Coolers is shown in Figure A.1. The system includes the process cooler, associated piping and block valves, and Freon condenser and connected piping. Based on the neutronics analysis, the top event of interest is the failure to prevent water ingress to the cooler. The initial conditions are that the system, in its unfailed state, is shut down with all block valves closed and the recycle cooling water removed from service.

\subsection{FAULT TREE CONSTRUCTION}

The level of resolution to which a fault tree can realistically be developed is limited by the availability of reliability information. The level of detail of the analysis is the component level in the system for which reliability data is available. The development of component-level basic faults to the next lower level of detail is not necessary to adequately assess the system performance. The fault tree for the Building K-31 Booster Station Coolers is shown in Figure A.2.

\subsection{QUALITATIVE EVALUATION}

The fault tree in Figure A.2 is a graphical representation of component failure modes and effects analysis with the specified top system event (failure to prevent water ingress to the cooler). The fault tree is evaluated to determine all unique combinations of component failures that cause the top event (the system modes of failure). The system modes of failure (minimal cutsets) are tabulated in Table A.1. 


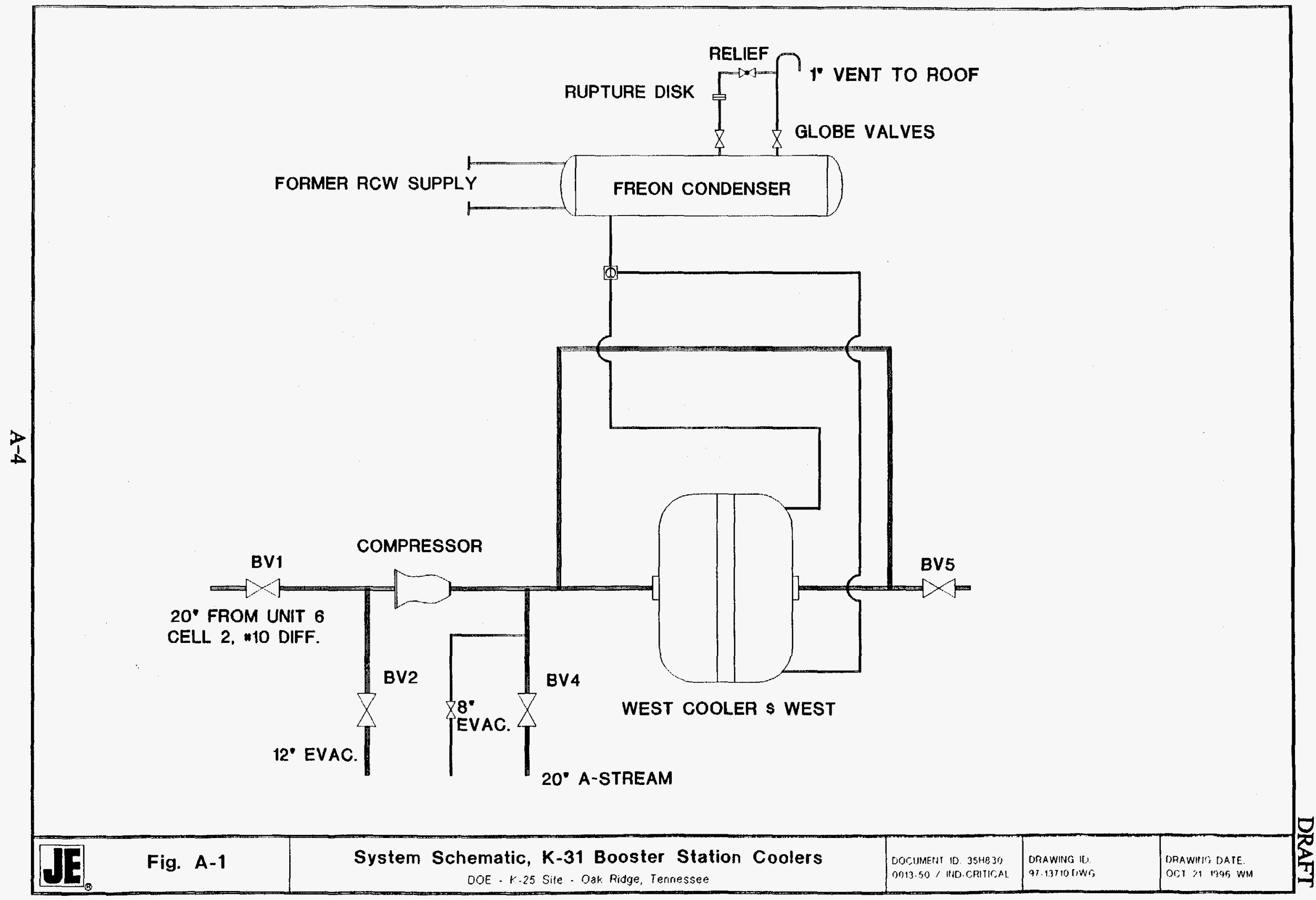




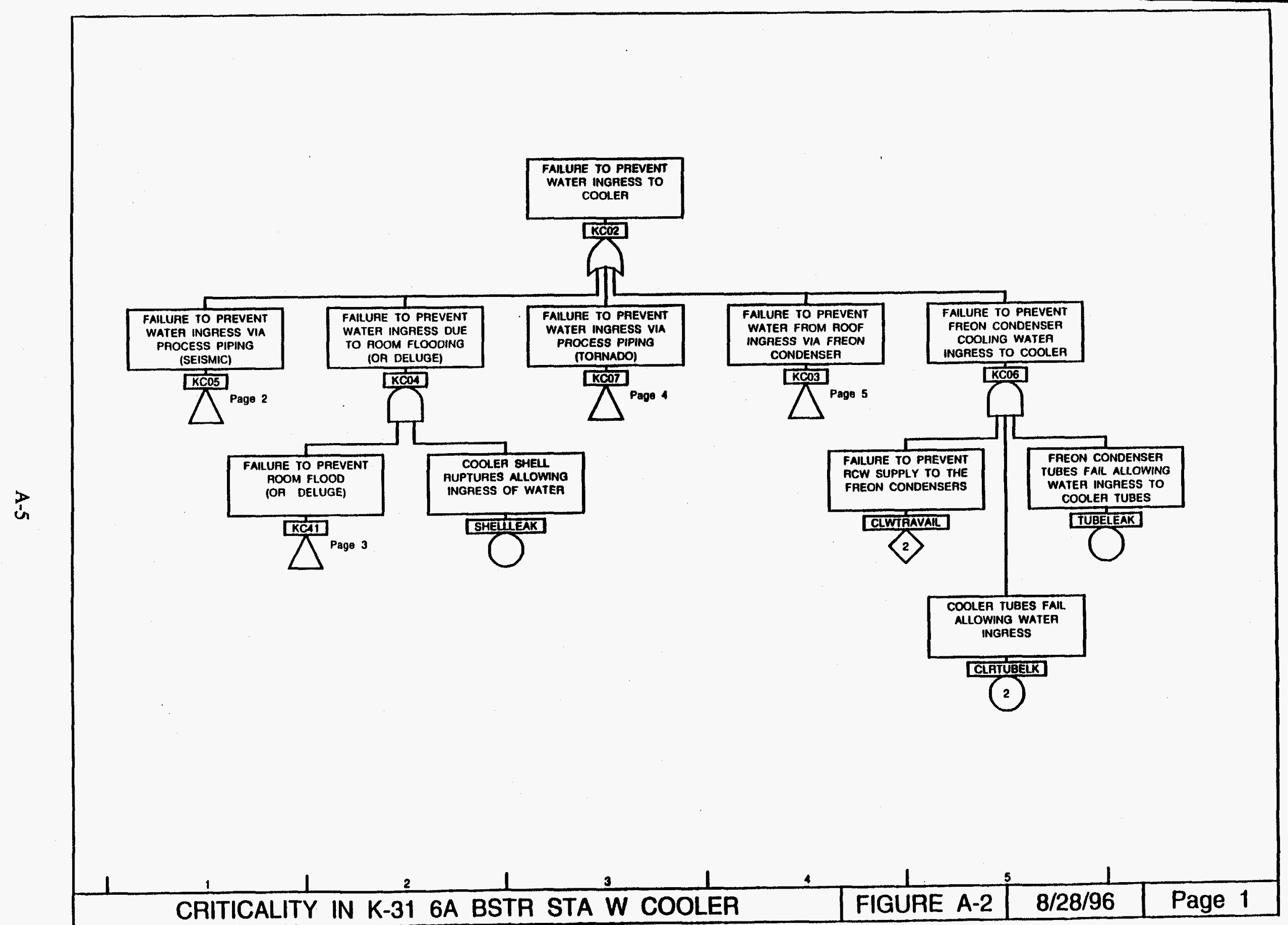




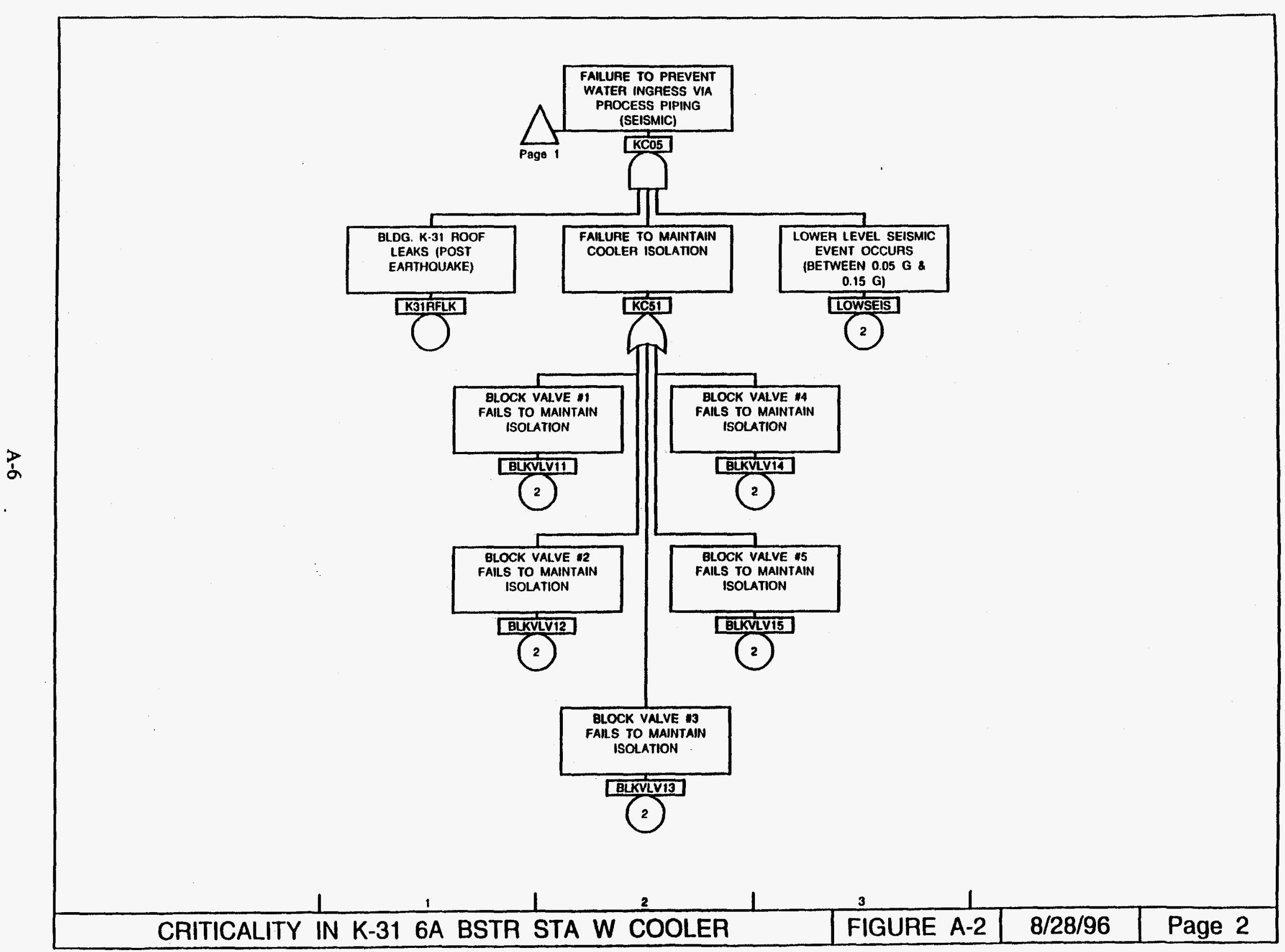




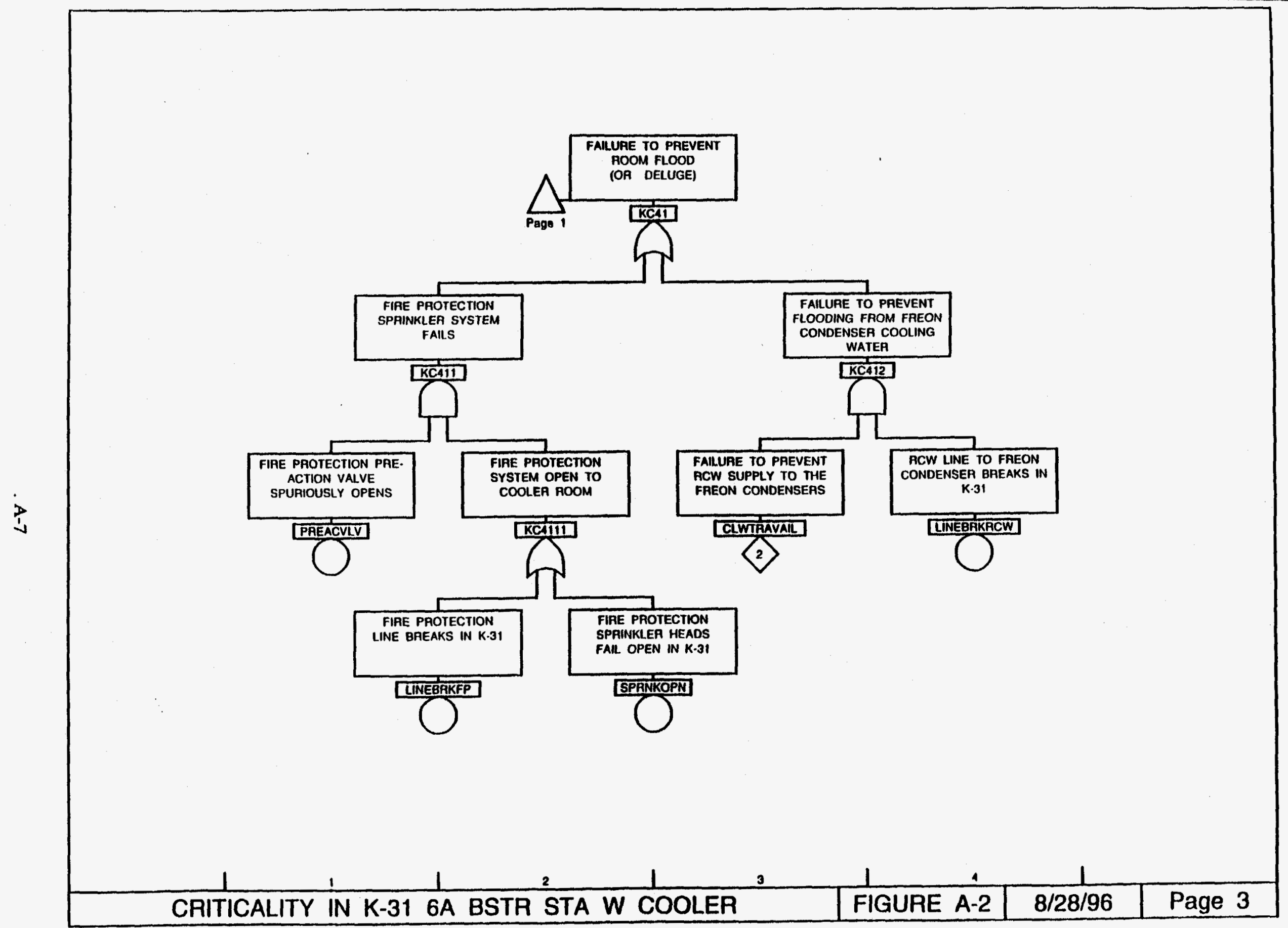





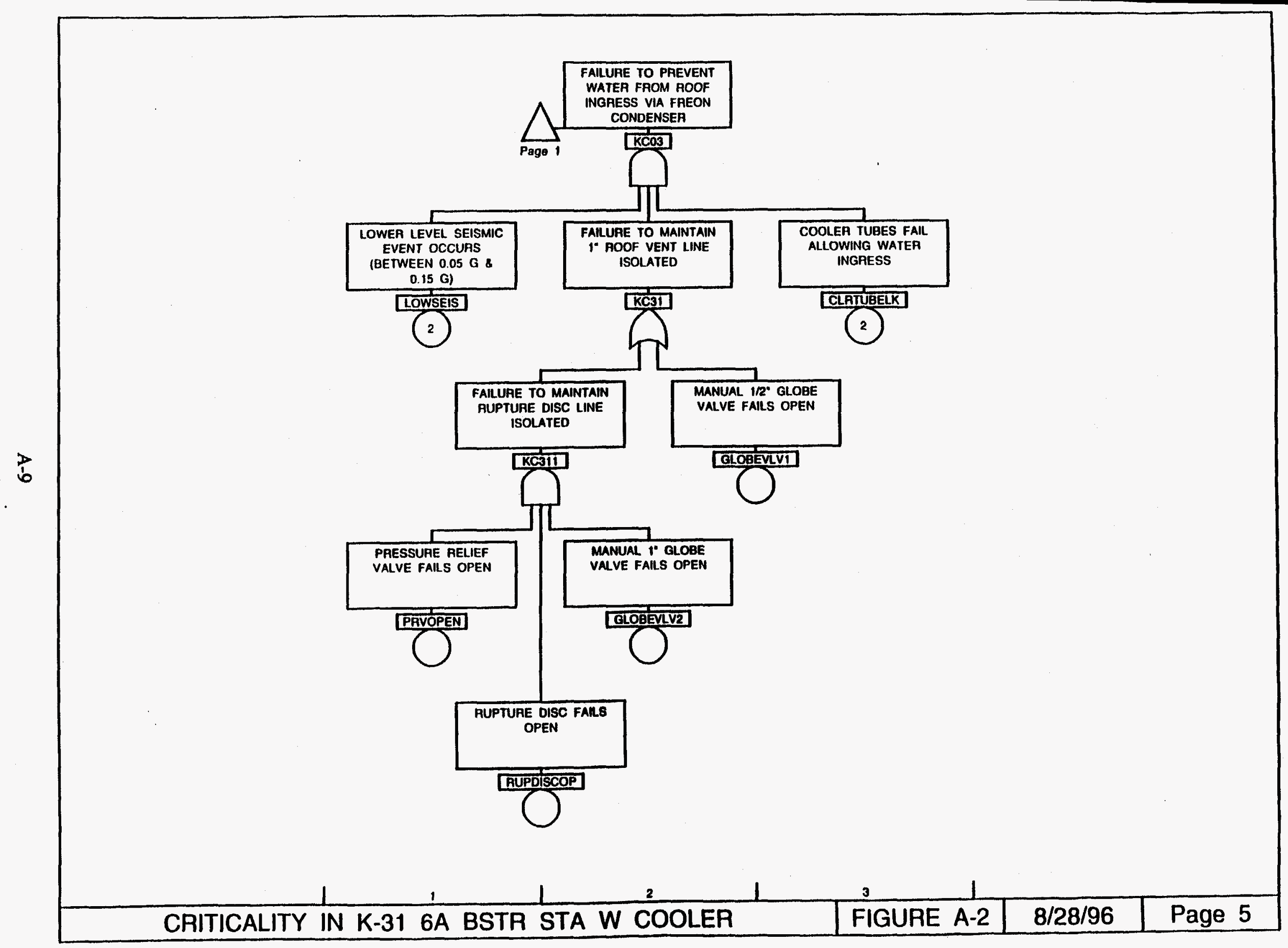


Table A.1. Minimal cutset report, Building K-31, K-25 Site, Oak Ridge, Tennessee

\begin{tabular}{|c|c|c|c|c|}
\hline 16 & 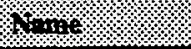 & 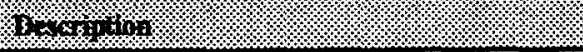 & 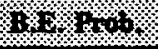 & $140,160+10$ \\
\hline \multicolumn{2}{|c|}{ Top event } & \multicolumn{2}{|l|}{ Failure to prevent water ingress to the cooler } & $9.91 E-09$ \\
\hline \multirow[t]{2}{*}{ 1) } & BLKVLV11 & Block valve \#1 fails to maintain isolation & 3.65E-05 & $1.03 \mathrm{E}-09$ \\
\hline & TOR113 & Tornado strike with wind speeds of $<113 \mathrm{mph}$ & $2.83 \mathrm{E}-05$ & \\
\hline \multirow[t]{2}{*}{ 2) } & BLKVLV12 & Block valve $\# 2$ fails to maintain isolation & $3.65 \mathrm{E}-05$ & $1.03 \mathrm{E}-09$ \\
\hline & TOR113 & Tomado strike with wind speeds $<113 \mathrm{mph}$ & $2.83 \mathrm{E}-05$ & \\
\hline \multirow[t]{2}{*}{ 3) } & BLKVLV13 & Block valve \#3 fails to maintain isolation & $3.65 E-05$ & $1.03 E-09$ \\
\hline & TOR113 & Tornado strike with wind speeds $<113 \mathrm{mph}$ & $2.83 E-05$ & \\
\hline \multirow[t]{2}{*}{ 4) } & BLKVLV14 & Block valve $\# 4$ fails to maintain isolation & $3.65 \mathrm{E}-05$ & $1.03 \mathrm{E}-09$ \\
\hline & TOR113 & Tornado strike with wind speeds $<113 \mathrm{mph}$ & $2.83 E-05$ & \\
\hline \multirow[t]{2}{*}{ 5) } & BLKVLV15 & Block valve \#5 fails to maintain isolation & $3.65 \mathrm{E}-05$ & $1.03 \mathrm{E}-09$ \\
\hline & TOR113 & Tormado strike with wind speeds $<113 \mathrm{mph}$ & $2.83 \mathrm{E}-05$ & \\
\hline \multirow[t]{2}{*}{ 6) } & BLKVLV11 & Block valve \#1 fails to maintain isolation & $3.65 E-05$ & 9.45E-10 \\
\hline & K31RFLK & Building $\mathrm{K}-31$ roof leaks (post earthquake) & $1.34 \mathrm{E}-02$ & \\
\hline \multirow[t]{3}{*}{ 7) } & BLKVLV12 & Block valve \#2 fails to maintain isolation & $3.65 \mathrm{E}-05$ & 9.45E-10 \\
\hline & K3IRFLK & Building K-31 roof leaks (post earthquake) & $1.34 \mathrm{E}-02$ & \\
\hline & LOWSEIS & Lower level seismic event occurs & $1.93 \mathrm{E}-03$ & \\
\hline \multirow[t]{2}{*}{ 8) } & BLKVLV13 & Block valve $\# 3$ fails to maintain isolation & $3.65 \mathrm{E}-05$ & $9.45 \mathrm{E}-10$ \\
\hline & LOWSEIS & Lower level seismic event occurs & $1.93 \mathrm{E}-03$ & \\
\hline \multirow[t]{3}{*}{ 9) } & BLKVLV14 & Block valve \#4 fails to maintain isolation & $3.65 \mathrm{E}-05$ & $9.45 \mathrm{E}-10$ \\
\hline & K31RFLK & Building $K-31$ roof leaks (post earhquake) & $1.34 \mathrm{E}-02$ & \\
\hline & LOWSEIS & Lower level seismic event occurs & $1.93 E-03$ & \\
\hline \multirow[t]{3}{*}{ 10) } & BLKVLV15 & Block valve \#5 fails to maintain isolation & $3.65 \mathrm{E}-05$ & $9.45 \mathrm{E}-10$ \\
\hline & K31RFLK & Building K-31 roof leaks (post earthquake & $1.34 \mathrm{E}-02$ & \\
\hline & LOWSEIS & Lower level seismic event occurs & $1.93 E-03$ & \\
\hline \multirow[t]{3}{*}{ 11) } & CLRTUBELK & Cooler tubes fail allowing water ingress & 2.63E-05 & $2.22 \mathrm{E}-11$ \\
\hline & GLOBEVLV1 & Manual $1 / 2$-in. globe valve fails open & $4.38 \mathrm{E}-04$ & \\
\hline & LOWSEIS & Lower level seismic event occurs & $1.93 \mathrm{E}-03$ & \\
\hline \multirow[t]{5}{*}{ 12) } & CLRTUBELK & Cooler ubes fail allowing water ingress & $2.63 \mathrm{E}-05$ & 8.53E-14 \\
\hline & GLOBEVLV2 & Manual 1-in. globe valve fails open & $4.38 E-04$ & \\
\hline & LOWSEIS & Lower level seismic event occurs & $1.93 \mathrm{E}-03$ & \\
\hline & PRVOPEN & Pressure relief valve fails open & $4.38 \mathrm{E}-02$ & \\
\hline & RUPDISCOP & Rupture disc fails open & $8.76 \mathrm{E}-02$ & \\
\hline
\end{tabular}


Table A.1. (continued)

\begin{tabular}{|c|c|c|c|c|}
\hline 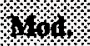 & 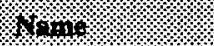 & 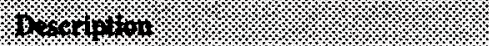 & 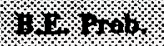 & $8,0.645,004$ \\
\hline \multirow[t]{3}{*}{ 13) } & CLWTRAVAIL & Failure to prevent $R C W$ supply & $5.00 \mathrm{E}-09$ & $5.19 \mathrm{E}-18$ \\
\hline & LNEBRKRCW & RCW line to freon condenser breaks & $4.38 \mathrm{E}-06$ & \\
\hline & SHELLLEAK & Cooler shell ruptures allowing ingress & 2.37E-04 & \\
\hline \multirow[t]{3}{*}{ 14) } & CLRTUBELK & Cooler ubes fail allowing water ingress & $2.63 \mathrm{E}-05$ & $3.46 \mathrm{E}-18$ \\
\hline & CLWTRAVAIL & Failure to prevent RCW supply & $5.00 \mathrm{E}-09$ & \\
\hline & TUBELEAK & Freon condenser tubes fail & 2.63E-05 & \\
\hline \multirow[t]{3}{*}{ 15) } & PREACVLV & Fire protection preaction valve opens & $1.25 \mathrm{E}-08$ & $2.22 \mathrm{E}-20$ \\
\hline & SHELLLEAK & Cooler shell nupures allowing ingress & $2.37 \mathrm{E}-04$ & \\
\hline & SPRNKOPN & Fire protection sprinkler heads fail open & $7.50 \mathrm{E}-09$ & \\
\hline \multirow[t]{3}{*}{ 16) } & LINEBRKFP & Fire protection line breaks in $\mathrm{K}-31$ & $1.25 \mathrm{E}-10$ & $3.70 \mathrm{E}-22$ \\
\hline & PREACVLV & Fire protection preaction valve opens & $1.25 \mathrm{E}-08$ & \\
\hline & SHELLLEAK & Cooler shell nupures allowing ingress & 2.37E-04 & \\
\hline
\end{tabular}

B.E. = basic event

CS. = cutset

in. $=$ inch

Mod. = module $\mathrm{mph}=$ miles per hour

Prob. = probability

$\mathrm{RCW}=$ recirculating cooling water 


\subsection{QUANTITATIVE EVALUATION}

The quantitative evaluations include determining the probability of occurrence for each basic event and determining the probability of occurrence of the top event. For this analysis, the negative exponential distribution technique is used. The evaluation of this fault tree was done using the CAFTA + computer program.

\section{MINIMAL CUTSET PROBABILITY}

The probability of occurrence of a minimal cutset, a system mode of failure, is the probability that all of the basic events contained in the minimal cutset have occurred. Because basic events are independent, the probability of occurrence is the product of the probabilities of the individual basic events that the minimal cutset contains. Thus, if $F_{n}$ denotes the probability of occurrence of a minimal cutset, then $F_{n}$ is the intersection or product of the basic event probabilities:

$$
F_{n}=F_{1} * F_{2} * F_{3} * \ldots F_{i}
$$

where $F_{1}, F_{2}$, etc., represent the probabilities of occurrence of the component critical failure modes represented by the basic events and $i$ is the number of basic events in the minimal cutset.

Once the probability of occurrence has been determined for each minimal cutset of the fault tree, the minimal cutsets can be numerically ranked in descending order. This ranking illustrates system modes of failure in terms of the mode most likely to occur. This ranking is shown in Table A.1.

\section{BASIC EVENT PROBABILITY}

Basic events in a fault tree often represent component critical failure modes. To evaluate the tree, each basic event must have a numerical probability assigned. The probability associated with a basic event will be the probability of occurrence of the component critical failure mode identified in the fault tree. For this analysis, the technique used to estimate the probability of failure of a component involves the negative exponential distribution. 
The component failure rate is the numerical probability that the component experiences at least one failure during a specified time period $t$ (exposure time). The component failure rate for a specified time can be calculated by the following:

$$
F(t)=1-R(t)
$$

where

$$
\begin{aligned}
& F(t) \quad=\text { probability of failure (unreliability) } \\
& R(t) \quad=\text { probability of success (reliability) }
\end{aligned}
$$

The reliability of any component for a specified time $t$ can be calculated exactly using the equation:

$$
R(t)=\exp \left[-t I \int{ }^{2} h(t) d t\right]
$$

where

$$
\begin{aligned}
& h(t) \quad=\text { time dependent failure rate } \\
& t \quad=\text { specified time interval beginning at } t_{1} \text { and ending at } t_{2}
\end{aligned}
$$

The use of the negative exponential distribution relies on data not being available to give an accurate description of the time-dependent failure rate; for many components, there is a time when the failure rate remains relatively constant. This is especially true of the components associated with these coolers because the systems are shut down with no process fluid in the system. The systems are also at atmospheric pressure. The components are not being cycled or stressed. Therefore, under these conditions, the reliability reduces to:

$$
R(t)=\exp [-\lambda t]
$$

where

$\lambda=$ constant component failure rate

For small values of $\lambda t(\leq 0.1)$, the reliability can be approximated by:

$$
R(t)=1-\lambda t
$$


Therefore, the probability of failure can be closely approximated by:

$$
F(t)=\lambda t
$$

To use these equations to estimate the probability of failure of a component during a specified time interval, it is assumed that the component's failure rate for the mode of concern is known and remains constant over the time interval of interest. Also, it is assumed that the component is functioning properly at the start of the time interval. 
BASIC EVENT

\title{
BLKVLV11, BLKVLV12, BLKVLV13, BLKVLV14, \& BLKVLV15 FAULT TREE WCLR-Y.CAF PAGE 2, ZONE 2 \& PAGE 4, ZONE 1
}

\author{
BLOCK VALVE \\ FAILS TO MAINTAIN ISOLATION
}

These events are the probability that the normally closed block valves in the process system piping fail (or rupture) to an open status allowing any water that might enter the process piping access to the $\mathrm{UO}_{2} \mathrm{~F}_{2}$ deposit in the cooler. The failure rate for this basic event is from the "Generic Failure Data Base for Light Water and Liquid Sodium Reactor PRAs," EGG-SSRE-8875, February 1990. The value, 5.00E-08 per hour, is the failure rate $(\lambda)$ due to internal rupture of a manual valve in water or steam working fluids. The rate applies equally to the five paths identified where water could enter the cooler. The rate is conservative because it applies to process systems containing working fluids where higher pressures are experienced. The cooler is in a shutdown mode with no process fluid in the system and is at atmospheric pressure. These block valves appear in both the seismic and tomado accident scenarios. If a seismic event or tornado of these magnitudes were to occur, personnel would seal the ruptured expansion joints with plastic within one month or 730 hours. Therefore, the exposure time ( $t$ ) for the block valve failures would be 730 hours and the probability is:

$$
\begin{aligned}
& P=\lambda t \\
& P=(5.00 E-08 / h r) *(7.30 E 02 \mathrm{hrs}) \\
& P=3.65 E-05
\end{aligned}
$$




\section{BASIC EVENT \\ CLRTUBELK}

FAULT TREE WCLR-Y.CAF PAGE 1, ZONE 5 \& PAGE 5. ZONE 3

\section{COOLER TUBES FAIL ALLOWING WATER INGRESS}

This event is the probability that the cooling tubes inside the cooler fail or rupture providing a path for water ingress to cooler and the $\mathrm{UO}_{2} \mathrm{~F}_{2}$ deposit. The failure rate for this basic event is from the "Generic Failure Data Base for Light Water and Liquid Sodium Reactor PRAs," EGG-SSRE-8875, February 1990. The value, 3.00E09 per hour, is the failure rate $(\lambda)$ due to internal leakage of tubes in a heat exchanger in water or steam working fluids. The rate is conservative because it applies to process systems containing working fluids where higher pressures are experienced. The cooler is in a shut-down mode with no process fluid in the system and is at atmospheric pressure. The exposure time $(t)$ for this event would be one year or 8,760 hours and the probability is:

$$
\begin{aligned}
& P=\lambda t \\
& P=(3.00 E-09 / h r) *(8.76 \mathrm{E} 03 \mathrm{hrs}) \\
& P=2.63 E-05
\end{aligned}
$$




\begin{tabular}{|c|}
\hline BASIC EVENT \\
CLWTRAVAIL \\
FAULT TREE WCLR-Y.CAF PAGE 1 , ZONE 4 \& PAGE 3, ZONE 3 \\
FAILURE TO PREVENT RCW \\
SUPPLY TO THE FREON CONDENSER \\
\hline
\end{tabular}

This event is the probability that raw cooling water is supplied to the freon condenser. The RCW is no longer in service. The RCW lines are actually dry and there are no pumps or water reservoir to supply water. Based on engineering judgement this failure rate $(\lambda)$ is estimated to be $5.00 \mathrm{E}-09$ per hour. The exposure time (t) for this event would be one year or 8,760 hours and the probability is:

$$
\begin{aligned}
& P=\lambda t \\
& P=(5.00 E-09 / h r) *(8.76 E 03 \mathrm{hrs}) \\
& P=4.38 \mathrm{E}-05
\end{aligned}
$$




\section{BASIC EVENT \\ LINEBRKFP \\ FAULT TREE WCLR-Y.CAF PAGE 3, ZONE 2 \\ FIRE PROTECTION LINE BREAKS \\ IN BUILDING K-31}

This event is the probability that the fire protection line breaks in Building $\mathrm{K}-31$ providing water that would flood or deluge the cooler. The failure rate for this basic event is from the "Generic Failure Data Base for Light Water and Liquid Sodium Reactor PRAs," EGG-SSRE-8875, February 1990. This rate, 5.00E-10 per foot per hour. Based on walkdowns, it is assumed that only 10 feet of fire protection piping had the potential to wet or deluge the cooler area. Since there are no fire protection piping inside the sheet metal housing, it was assumed that only $10 \%$ had the potential for wetting the actual cooler. Therefore, the rate $(\lambda)$ for this basic event was taken to be:

$$
\begin{aligned}
& \lambda=(5.00 \mathrm{E}-10 / \mathrm{ft} . \mathrm{hr}) *(10 \mathrm{ft} .) *(0.1) \\
& \lambda=5.00 \mathrm{E}-10 / \mathrm{hr}
\end{aligned}
$$

The sprinkler system initiation due to the failed or ruptured line would be annunciated at the site fire department. The time for the fire department to respond and valve off the ruptured line is estimated to be fifteen minutes or 0.25 hours. Therefore, the mission time ( $t$ ) for the fire protection line break failure would be 0.25 hours and the basic event probability would be:

$$
\begin{aligned}
& P=\lambda t \\
& P=(5.00 \mathrm{E}-10 / \mathrm{hr}) *(2.5 \mathrm{E}-01 \mathrm{hrs}) \\
& P=1.25 \mathrm{E}-10
\end{aligned}
$$




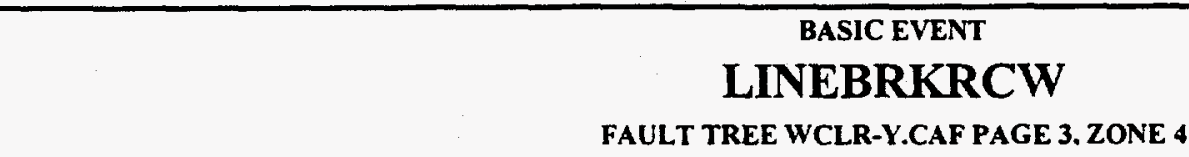

\section{RAW COOLING WATER LINE TO THE FREON CONDENSER BREAKS IN BUILDING K-31}

This event is the probability that the raw cooling water line breaks in Building K-31 providing water that would flood or deluge the cooler. The failure rate for this basic event is from the "Generic Failure Data Base for Light Water and Liquid Sodium Reactor PRAs," EGG-SSRE-8875, February 1990. This rate, 5.00E-10 per foot per hour, is for the rupture of the pipe. Since there are no raw cooling water piping inside the sheet metal housing, it was assumed that only 10 feet of piping had the potential for wetting the cooler area and that only $10 \%$ had the potential for wetting the actual cooler. Therefore, the rate $(\lambda)$ for this basic event was taken to be $5.00 \mathrm{E}-10$ per hour.

$$
\begin{aligned}
& \lambda=(5.00 \mathrm{E}-10 / \mathrm{ft}-\mathrm{hr}) *(10 \mathrm{ft}) *(0.1) \\
& \lambda=5.00 \mathrm{E}-10 / \mathrm{hr}
\end{aligned}
$$

The rate is conservative because it applies to process systems containing working fluids where higher pressures are experienced. The cooler is in a shut-down mode with no water in the system and is at atmospheric pressure. The mission time ( $t$ ) for this event is one year or 8,760 hours and the probability is:

$$
\begin{aligned}
& P=\lambda t \\
& P=(5.00 E-10 / h r) *(8,760 \mathrm{hrs}) \\
& P=4.38 E-06
\end{aligned}
$$




\section{BASIC EVENT \\ LOWSEIS}

FAULT TREE WCLR-Y.CAF PAGE 2, ZONE 3 \& PAGE 5. ZONE 1

\section{LOWER LEVEL SEISMIC EVENT OCCURS ( BETWEEN 0.05 G AND 0.15 G )}

This event is the probability that a low level seismic event occurs and rupture the expansion joints in Building $\mathrm{K}-31$. The seismic events that could cause these ruptures have a peak ground acceleration between $0.05 \mathrm{G}$ and $0.15 \mathrm{G}$ (ref. 16 ). The seismic hazard curve from the "Natural Phenomena Hazards Modeling Project: Seismic Hazards Models for Department of Energy Sites," UCRL-53582, 1984 shows that the annual probability of experiencing an earthquake with a peak ground acceleration of $0.05 \mathrm{G}$ or higher is $2.5 \mathrm{E}-02$ and for $0.15 \mathrm{G}$ or higher is $1.9 \mathrm{E}-03$. These probabilities, however, include contributions from more severe events. Therefore, the annual probability of experiencing an earthquake with peak ground acceleration between $0.05 \mathrm{G}$ and 0.15 $\mathrm{G}$ is the difference between the two annual exceedance probabilities.

$$
\begin{aligned}
& \lambda=[(2.5 \mathrm{E}-02 / \mathrm{yr})-(1.9 \mathrm{E}-03 / \mathrm{yr})] *[1 \mathrm{yr} / 8,760 \mathrm{hrs}] \\
& \lambda=2.64 \mathrm{E}-06 / \mathrm{hr}
\end{aligned}
$$

Also, it is assumed that if an earthquake occurs then the expansion joints fail and, thereby, provide a potential path for water ingress to the cooler and the deposit of concern. It is also assumed that a sufficient source of water is available post earthquake. If a seismic event of this magnitude occurs, personnel would seal the ruptured expansion joints within one month. Therefore, the mission time $(t)$ for this event would be one month or 730 hours and the probability is:

$$
\begin{aligned}
& P=\lambda t \\
& P=(2.63 \mathrm{E}-06 / \mathrm{hr}) *(730 \mathrm{hrs}) \\
& P=1.93 \mathrm{E}-03
\end{aligned}
$$




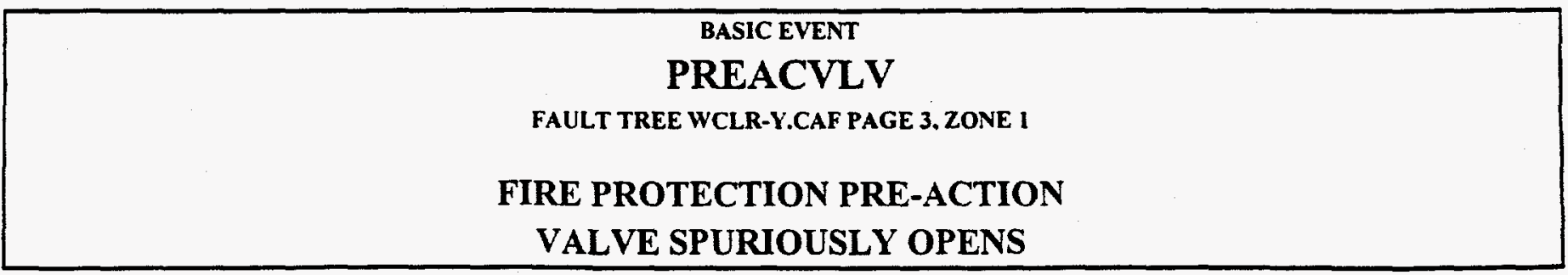

This event is the probability that the fire protection system pre-action valve opens spuriously providing water to the overhead fire protection system piping. This could be the water source that could flood or deluge the cooler. The failure rate for this basic event is from the "Generic Failure Data Base for Light Water and Liquid Sodium Reactor PRAs," EGG-SSRE-8875, February 1990. The failure rate $(\lambda), 5.00 \mathrm{E}-08$ per hour, is for the spurious operation of the valve. The failed pre-action valve would be annunciated at the site fire department. The time for the fire department to respond and shut off the water is estimated to be fifteen minutes or 0.25 hours. Therefore, the mission time $(\mathrm{t})$ for the fire protection line break failure would be 0.25 hours and the basic event probability would be:

$$
\begin{aligned}
& P=\lambda t \\
& P=(5.00 \mathrm{E}-08 / \mathrm{hr}) *(0.25 \mathrm{hrs}) \\
& P=1.25 \mathrm{E}-08
\end{aligned}
$$




\section{BASIC EVENT \\ PRVOPEN}

FAULT TREE WCLR-Y.CAF PAGE 5, ZONE 1

PRESSURE RELIEF VALVE

FAILS OPEN

This event is the probability that the pressure relief valve opens spuriously providing a path for water from the roof to enter the Freon condenser. The failure rate for this basic event is from the "Generic Failure Data Base for Light Water and Liquid Sodium Reactor PRAs," EGG-SSRE-8875, February 1990. The rate $(\lambda), 5.00 E-06$ per hour, is for the spurious operation of the valve. The rate is conservative because it applies to process systems containing working fluids where higher pressures are experienced. The cooler is in a shut-down mode with no Freon in the system and is at atmospheric pressure. The mission time for this event would be one year or 8,760 hours. The probability is:

$$
\begin{aligned}
& \mathrm{P}=\lambda \mathrm{t} \\
& \mathrm{P}=(5.00 \mathrm{E}-06 / \mathrm{hr}) *(8,760 \mathrm{hrs}) \\
& \mathrm{P}=4.38 \mathrm{E}-02
\end{aligned}
$$




\section{BASIC EVENT}

RUPDISCOP

FAULT TREE WCLR-Y.CAF PAGE 5. ZONE 2

\section{RUPTURE DISC}

FAILS OPEN

This event is the probability that the rupture disc fails open providing a path for water from the roof to enter the freon condenser. The failure rate for this basic event is from the "Generic Failure Data Base for Light Water and Liquid Sodium Reactor PRAs," EGG-SSRE-8875, February 1990. The rate $(\lambda), 1.00 E-05$ per hour, is for the premature opening of the rupture disc. The rate is conservative because it applies to process systems containing working fluids where higher pressures are experienced. The cooler is in a shut-down mode with no process fluid in the system and is at atmospheric pressure. The mission time ( $t)$ for this event is one year or 8,760 hours. The probability is:

$$
\begin{aligned}
& \mathrm{P}=\lambda \mathrm{t} \\
& \mathrm{P}=(1.00 \mathrm{E}-05 / \mathrm{hr}) *(8,760 \mathrm{hrs}) \\
& \mathrm{P}=8.76 \mathrm{E}-02
\end{aligned}
$$




\section{BASIC EVENT}

SHELLLEAK

FAULT TREE WCLR-Y.CAF PAGE 1, ZONE 2

\section{COOLER SHELL RUPTURES}

\section{ALLOWING INGRESS}

OF WATER

This event is the probability that the cooler shell ruptures providing a path for any water outside the shell to enter the cooler. If this occurred water from a room flood or deluge could reach the deposit of concern. The failure rate for this basic event is from the "Generic Failure Data Base for Light Water and Liquid Sodium Reactor PRAs," EGG-SSRE-8875, February 1990 which quotes a value from the Seabrook Nuclear Plant PRA. The rate $(\lambda), 2.70 \mathrm{E}-08$ per hour, is for the external rupture of the cooler shell. The rate is conservative because it applies to process systems containing working fluids where higher pressures are experienced. The cooler is in a shut-down mode with no process fluid in the system and is at atmospheric pressure. The mission time for this event is:

$$
\begin{aligned}
& \mathrm{P}=\lambda \mathrm{t} \\
& \mathrm{P}=(2.70 \mathrm{E}-08 / \mathrm{hr}) *(8,760 \mathrm{hrs}) \\
& \mathrm{P}=2.37 \mathrm{E}-04
\end{aligned}
$$




\section{BASIC EVENT \\ SPRNKOPN \\ FAULT TREE WCLR-Y.CAF PAGE 3, ZONE 3 \\ FIRE PROTECTION \\ SPRINKLER HEADS \\ FAIL OPEN IN K-31}

This event is the probability that the fire protection sprinkler heads in Building K-31 fail open allowing fire protection water to flood or deluge the cooler area. The failure rate for this basic event is from the "Generic Failure Data Base for Light Water and Liquid Sodium Reactor PRAs," EGG-SSRE-8875, February 1990. Since no data existed specifically for sprinkler heads, a value for external leakage for manual valves was used. The rate $(\lambda), 3.00 \mathrm{E}-08$ per hour, is for the failure of the sprinkler heads. The sprinkler system initiation due to the failed sprinkler heads would be annunciated at the site fire department. The time for the fire department to respond and valve off the failed components is estimated to be fifteen minutes or 0.25 hours. Therefore, the mission time ( $t$ ) for the fire protection line break failure would be 0.25 hours and the basic event probability would be:

$$
\begin{aligned}
& P=\lambda t \\
& P=(3.00 \mathrm{E}-08 / \mathrm{hr}) *(0.25 \mathrm{hrs}) \\
& P=7.50 \mathrm{E}-09
\end{aligned}
$$




\section{TORNADO STRIKE WITH WIND SPEEDS OF NO GREATER THAN 113 MPH}

This event is the probability that a tornado strikes Building K-31 with wind speeds up to 113 miles per hour. The failure rate for this basic event is taken from the "Preliminary Probabilistic Criticality Assessment of Selected Low-Enriched Uranium Facilities at the Oak Ridge K-25 Site," K/D-6048, January 1993. The rate $(\lambda), 3.40 \mathrm{E}-04$ per year, is for a tornado strike on Building $\mathrm{K}-31$ with wind speeds of no greater than 113 miles per hour. For the purposes of this analysis, it is conservatively assumed that if a tornado strikes the building then a missile with sufficient energy is generated to penetrate the building and damage the process target area of concern (expansion joints). Other process equipment (pipes, valves, coolers, etc.) would not be damaged by these tornado generated missiles. It is also assumed that water is available as a result of the tornado to enter the damaged process equipment with potential to reach the deposit of concern. If a tornado of this magnitude was to occur, personnel would seal the ruptured expansion joints within one month of 730 hours. Therefore, the mission time for this event is 730 hours and the probability is:

$$
\begin{aligned}
& \mathrm{P}=\lambda \mathrm{t} \\
& \mathrm{P}=(3.40 \mathrm{E}-04 / \mathrm{yr}) *(1 \mathrm{yr} / 8,760 \mathrm{hrs}) *(730 \mathrm{hrs}) \\
& \mathrm{P}=2.83 \mathrm{E}-05
\end{aligned}
$$




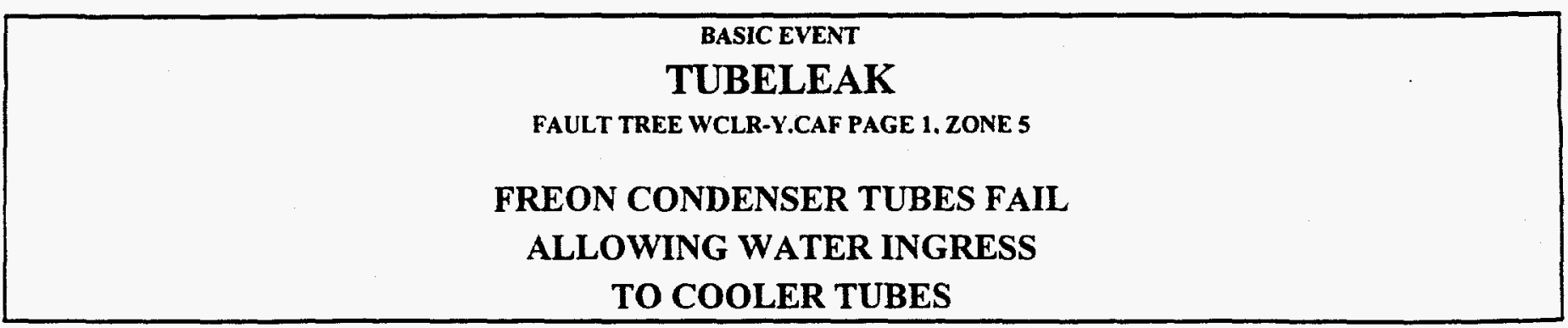

This event is the probability that the cooling tubes inside the Freon condenser fail or rupture providing a path for water ingress to the cooler tubes and the $\mathrm{UO}_{2} \mathrm{~F}_{2}$ deposit. The failure rate for this basic event is from the "Generic Failure Data Base for Light Water and Liquid Sodium Reactor PRAs," EGG-SSRE-8875, February 1990. The failure rate $(\lambda), 3.00 \mathrm{E}-09$ per hour, is the failure rate due to internal leakage of tubes in a heat exchanger in water or steam working fluids. The rate is conservative because it applies to process systems containing working fluids where higher pressures are experienced. The cooler is in a shut-down mode with no process fluid in the system and is at atmospheric pressure. The mission time $(t)$ for this event is one year or 8,760 hours and the probability is:

$$
\begin{aligned}
& P=\lambda t \\
& P=(3.00 \mathrm{E}-09 / \mathrm{hr}) *(8,760 \mathrm{hrs}) \\
& P=2.63 \mathrm{E}-05
\end{aligned}
$$




\section{APPENDIX B}

COMMENTS AND RESPONSES, INDEPENDENT EVALUATION OF CRITICALITY ISSUES ASSOCIATED WITH URANIUM DEPOSITS AT THE K-25 SITE, OAK RIDGE, TENNESSEE 


\section{OAK RIDGE PROGRAM DIVISION DOCUMENT REVIEW FORM}

DOCUMENT TITLE: Independent Evaluation of Criticality Issues Associated with Uranium Deposits at the

K-25 Site, Oak Ridge, Tennessee

DATE COMMENTS

DOCUMENT NUMBER: JE/ER/4

NAME OF REVIEWER: M. J. Haire

ORGANIZATION: Lockheed Martin

Energy Systems

DATE COMMENTS TRANSMITTED:

\section{COMMENT CODE}

\begin{tabular}{||l|l|l||}
\hline $\begin{array}{l}\mathrm{D}=\text { Deficiency of some type; cite } \\
\text { applicable regulation(s) }\end{array}$ & $\begin{array}{l}\mathrm{C}=\text { Clarification or additional information needed; } \\
\text { response may be in summary of comment responses } \\
\text { and/or next version of document }\end{array}$ & $\begin{array}{l}\text { E = Editorial comments will be noted } \\
\text { and corrected, but dropped from the } \\
\text { summary of comment responses }\end{array}$ \\
\hline
\end{tabular}

\begin{tabular}{|c|c|c|c|c||}
\hline $\begin{array}{c}\text { COMMENT } \\
\text { NO. }\end{array}$ & \multicolumn{1}{|c|}{$\begin{array}{c}\text { SECT/ } \\
\text { PAGE }\end{array}$} & COMMENT & RESPONSE & $\begin{array}{c}\text { ACCEPT/ } \\
\text { REJECT }\end{array}$ \\
\hline 1. & General & $\begin{array}{l}\text { I disagree that the double contingency principle } \\
\text { is met deposits in the K-31 Building coolers, as } \\
\text { stated near the end of Chapter 3. A single }\end{array}$ & $\begin{array}{c}\text { Assuming that a compromise of the barrier is a } \\
\text { credible event, that single event would not lead } \\
\text { to a nuclear criticality in the K-31 coolers. A }\end{array}$ & \\
\hline
\end{tabular}


OAK RIDGE PROGRAM DIVISION DOCUMENT REVIEW FORM

\begin{tabular}{|c|c|c|c|c|c|}
\hline \multicolumn{2}{|c|}{$\begin{array}{l}\mathrm{D}=\text { Deficiency of some type; cite } \\
\text { applicable regulation(s) }\end{array}$} & \multicolumn{2}{|c|}{$\begin{array}{l}\mathrm{C}=\text { Clarification or additional information } \\
\text { needed; response may be in summary of comment } \\
\text { responses and/or next version of document }\end{array}$} & \multicolumn{2}{|c|}{$\begin{array}{l}E=\text { Editorial comments will be noted } \\
\text { and corrected, but dropped from the } \\
\text { summary of comment responses }\end{array}$} \\
\hline \multirow[t]{2}{*}{$\begin{array}{l}\text { COMMENT } \\
\text { NO. }\end{array}$} & $\begin{array}{l}\text { SECT/ } \\
\text { PAGE }\end{array}$ & COMMENT & & RESPONSE & $\begin{array}{l}\text { ACCEPT/ } \\
\text { REJECT }\end{array}$ \\
\hline & & $\begin{array}{l}\text { credible event would lead to conditions in which } \\
\text { nuclear criticality event is possible. This event } \\
\text { is the compromise of the barrier between the } \\
\text { uranium in the cooler and ambient air. }\end{array}$ & \multicolumn{2}{|c|}{$\begin{array}{l}\text { puncture or crack would not lead to } \\
\text { deliquescence, because there would not be } \\
\text { sufficient circulation of moist air around the } \\
\text { deposits. This point is further discussed in } \\
\text { Response } 6 \text {. If deliquescence could occur, } \\
\text { neutronic calculations show that an additional } \\
\text { event creating reflection caused by the addition } \\
\text { of water into the cooler would also have to } \\
\text { occur before a criticality is possible. }\end{array}$} & \\
\hline 2. & General & $\begin{array}{l}\text { Regarding the fault tree analysis, I do not agree } \\
\text { with the calculated probability of } 2 \times 10^{-9} \text { for } \\
\text { conditions favorable for a nuclear criticality. }\end{array}$ & \multicolumn{2}{|c|}{$\begin{array}{l}\text { The fault tree has been modified to represent } \\
\text { water ingress into the cooler, and the calculated } \\
\text { probability has been revised. Explanation of } \\
\text { the basic events has also been added. }\end{array}$} & \\
\hline
\end{tabular}




\section{OAK RIDGE PROGRAM DIVISION DOCUMENT REVIEW FORM}

\begin{tabular}{|c|c|c|c|c|c|}
\hline \multicolumn{2}{|c|}{$\begin{array}{l}\mathrm{D}=\text { Deficiency of some type; cit } \\
\text { applicable regulation(s) }\end{array}$} & \multicolumn{2}{|c|}{$\begin{array}{l}C=\text { Clarification or additional information } \\
\text { needed; response may be in summary of comment } \\
\text { responses and/or next version of document }\end{array}$} & \multicolumn{2}{|c|}{$\begin{array}{l}\mathrm{E}=\text { Editorial comments will be noted } \\
\text { and corrected, but dropped from the } \\
\text { summary of comment responses }\end{array}$} \\
\hline $\begin{array}{l}\text { COMMENT } \\
\text { NO. }\end{array}$ & $\begin{array}{l}\text { SECT/ } \\
\text { PAGE }\end{array}$ & COMMENT & & RESPONSE & $\begin{array}{l}\text { ACCEPT/ } \\
\text { REJECT }\end{array}$ \\
\hline $2 a$. & & $\begin{array}{l}\text { Only equipment failures are included in the fault } \\
\text { tree analysis. Administrative (human factor) } \\
\text { failures should also be included. }\end{array}$ & $\begin{array}{l}\text { Administrativ } \\
\text { appropriate in } \\
\text { shutdown plar } \\
\text { worker involv } \\
\text { question. In } \\
\text { normally on t } \\
\text { impact the pr } \\
\text { administrative } \\
\text { cell flow and } \\
\text { (RWP) before } \\
\text { addition, this } \\
\text { disciplinary d } \\
\text { administrative } \\
\text { allow unautho } \\
\text { floor, and the } \\
\text { have to do da } \\
\text { combination } \\
\text { conclusion th } \\
\text { might cause d } \\
\text { coolers in Bu } \\
\text { rate and woul } \\
\text { significantly. }\end{array}$ & $\begin{array}{l}\text { human factor) failures are more } \\
\text { n operating plant than in a } \\
\text { in which there is little to no } \\
\text { nent with the equipment in } \\
\text { ilding K-31, workers are not } \\
\text { cell floor, so they would not } \\
\text { nt conditions. The existing } \\
\text { rocedures restrict access to the } \\
\text { quire Radiation Work Permits } \\
\text { ork access is granted. In } \\
\text { quires concurrence of eight } \\
\text { artments. Multiple } \\
\text { ailures would have to occur to } \\
\text { zed personnel access to the cell } \\
\text { nauthorized personnel would } \\
\text { age to the coolers. The } \\
\text { these factors results in the } \\
\text { administrative failures that } \\
\text { nage to the east and west } \\
\text { ing K-31 have lower occurrence } \\
\text { not affect the fault tree }\end{array}$ & \\
\hline
\end{tabular}


OAK RIDGE PROGRAM DIVISION DOCUMENT REVIEW FORM

\begin{tabular}{|c|c|c|c|c|c|}
\hline \multicolumn{2}{|c|}{$\begin{array}{l}D=\text { Deficiency of some type; ci } \\
\text { applicable regulation(s) }\end{array}$} & \multicolumn{2}{|c|}{$\begin{array}{l}C=\text { Clarification or additional information } \\
\text { needed; response may be in summary of comment } \\
\text { responses and/or next version of document }\end{array}$} & \multicolumn{2}{|c|}{$\begin{array}{l}\text { E = Editorial comments will be noted } \\
\text { and corrected, but dropped from the } \\
\text { summary of comment responses }\end{array}$} \\
\hline $\begin{array}{l}\text { COMMENT } \\
\text { NO. }\end{array}$ & $\begin{array}{l}\text { SECT/ } \\
\text { PAGE }\end{array}$ & COMMENT & & RESPONSE & $\begin{array}{l}\text { ACCEPT/ } \\
\text { REJECT }\end{array}$ \\
\hline $2 b$ & & $\begin{array}{l}\text { I do not agree with some of the equipment } \\
\text { failure rates input into basic events in the fault } \\
\text { tree. For example, the failure rates for heat } \\
\text { exchanger tubing may need to be reevaluated. } \\
\text { Coolant routinely leaked into the process gas } \\
\text { and recycle coolant water when the cascade was } \\
\text { operating. The amount of coolant leakage into } \\
\text { the process gas controlled by pressure } \\
\text { differentials. }\end{array}$ & $\begin{array}{l}\text { Failure rates } \\
\text { operating plar } \\
\text { have lower fa } \\
\text { documentatio } \\
\text { exchanger ha } \\
\text { valid. }\end{array}$ & $\begin{array}{l}\text { d are based on those for } \\
\text { A nonoperating plant would } \\
\text { re rates. Because there is no } \\
\text { lat the tubes for the heat } \\
\text { failed, the failure rates used are }\end{array}$ & \\
\hline $2 c$ & & $\begin{array}{l}\text { Deliquescence (absorbing moisture from air) } \\
\text { and condensation are two intermediate events } \\
\text { that should be added to the fault tree. }\end{array}$ & $\begin{array}{l}\text { The probabili } \\
\text { state is deem } \\
\text { 6). Deliques } \\
\text { criticality. A } \\
\text { necessary. T } \\
\text { mechanisms } \\
\text { ingress. }\end{array}$ & $\begin{array}{l}\text { of deliquescence in the current } \\
\text { incredible (see Responses } 1 \text { and } \\
\text { ce alone will not cause a } \\
\text { tional water ingress is } \\
\text { fault tree describes the failure } \\
\text { essary for this additional water }\end{array}$ & \\
\hline
\end{tabular}


OAK RIDGE PROGRAM DIVISION DOCUMENT REVIEW FORM

\begin{tabular}{|c|c|c|c|c|c|}
\hline \multicolumn{2}{|c|}{$\begin{array}{l}D=\text { Deficiency of some type; cite } \\
\text { applicable regulation(s) }\end{array}$} & \multicolumn{2}{|c|}{$\begin{array}{l}\mathrm{C}=\text { Clarification or additional information } \\
\text { needed; response may be in summary of comment } \\
\text { responses and/or next version of document }\end{array}$} & \multicolumn{2}{|c|}{$\begin{array}{l}\mathbf{E}=\text { Editorial comments will be noted } \\
\text { and corrected, but dropped from the } \\
\text { summary of comment responses }\end{array}$} \\
\hline $\begin{array}{l}\text { COMMENT } \\
\text { NO. }\end{array}$ & $\begin{array}{l}\text { SECT/ } \\
\text { PAGE }\end{array}$ & COMMENT & & RESPONSE & $\begin{array}{l}\text { ACCEPT/ } \\
\text { REJECT }\end{array}$ \\
\hline $2 d$. & & $\begin{array}{l}\text { Natural phenomena are not the only ways that } \\
\text { the boundary separating fissile material from air } \\
\text { could be ruptured. It is possible for a forklift, } \\
\text { or some other vehicle, to run into the coolers. } \\
\text { Also, falling concrete ceiling panels could } \\
\text { rupture the equipment. These types of events } \\
\text { should be incorporated into the fault tree. }\end{array}$ & $\begin{array}{l}\text { The equipme } \\
\text { fork lift to ge } \\
\text { Concrete ceil } \\
\text { found in Buil } \\
\text { applicable to } \\
\text { addition, the } \\
\text { some additio }\end{array}$ & $\begin{array}{l}\text { configuration will not allow a } \\
\text { o the cooler equipment. } \\
\text { panels described are only } \\
\text { ags } \mathrm{K}-25 \text { and } \mathrm{K}-27 \text { and are not } \\
\text { e Building K-31 coolers. In } \\
\text { Il enclosures would provide } \\
\text { level of protection. }\end{array}$ & \\
\hline $2 \mathrm{e}$ & & $\begin{array}{l}\text { Some calculated failure rates for basic events } \\
\text { seem low by a factor of } 24 \text {. The conversion } \\
\text { from failures per hour to failures per year is } \\
8,760 \text {, not } 365 \text { (e.g., the basic events } \\
\text { BLKLV11-15 and TOR113). }\end{array}$ & $\begin{array}{l}\text { The failure } p \\
\text { negative exp } \\
\text { failure rates } \\
\text { the appropria } \\
\text { basic events } \\
\text { ( } 8,760 \text { hours } \\
\text { Appendix C } \\
\text { explain the a }\end{array}$ & $\begin{array}{l}\text { babilities were calculated using a } \\
\text { ential distribution based on } \\
\text { m published documentation and } \\
\text { exposure time. Not all the } \\
\text { ve an exposure time of } 1 \text { year } \\
\text { The basic event descriptions in } \\
11 \text { be revised to identify and } \\
\text { ropriate exposure times used. }\end{array}$ & \\
\hline
\end{tabular}




\section{OAK RIDGE PROGRAM DIVISION DOCUMENT REVIEW FORM}

\begin{tabular}{|c|c|c|c|c|c|}
\hline \multicolumn{2}{|c|}{$\begin{array}{l}D=\text { Deficiency of some type; cite } \\
\text { applicable regulation(s) }\end{array}$} & \multicolumn{2}{|c|}{$\begin{array}{l}\mathrm{C}=\text { Clarification or additional information } \\
\text { needed; response may be in summary of comment } \\
\text { responses and/or next version of document }\end{array}$} & \multicolumn{2}{|c|}{$\begin{array}{l}\mathrm{E}=\text { Editorial comments will be noted } \\
\text { and corrected, but dropped from the } \\
\text { summary of comment responses }\end{array}$} \\
\hline $\begin{array}{l}\text { COMMENT } \\
\text { NO. }\end{array}$ & $\begin{array}{l}\text { SECT/ } \\
\text { PAGE }\end{array}$ & COMMENT & & RESPONSE & $\begin{array}{l}\text { ACCEPT/ } \\
\text { REJECT }\end{array}$ \\
\hline 3. & Section 1.4 & $\begin{array}{l}\text { NDA measurements are notoriously inaccurate } \\
\text { and are often low by a factor of } 2,3 \text {, or } 4 \text { (see } \\
\text { "Nuclear Criticality Safety Concerns of } \\
\text { Uranium Deposits in Cascade Equipment," M. } \\
\text { J. Plaster, et al., ANS } 1996 \text { Annual Meeting, } \\
\text { Reno, Nevada, June } 16-20,1996 \text { ). The } \\
\text { probability of the mass estimates being outside } \\
\text { the } \pm 50 \% \text { uncertainty is high (perhaps } 25 \% \text { ). } \\
\text { How does this affect the calculated fault tree } \\
\text { analysis probability? }\end{array}$ & \multicolumn{2}{|c|}{$\begin{array}{l}\text { The fault tree was always intended to assess the } \\
\text { probability of the failure to prevent water } \\
\text { ingress and has been modified accordingly. } \\
\text { NDA mass estimates do not affect that } \\
\text { probability. }\end{array}$} & \\
\hline 4. & $\begin{array}{l}\text { Page 5, Sect. } \\
2.2 .1 .1 \text {, last } \\
\text { sentence }\end{array}$ & $\begin{array}{l}\text { This sentence is not true ("criticality issues can } \\
\text { be avoided if water ingress into the cooler is } \\
\text { precluded"). Optimal moderation for the } \\
\text { deposits at these enrichments may occur when } \\
\text { the deposit has the appearance of being dry } \\
\text { (H/U < } 16 \text { ). Therefore, opening the equipment } \\
\text { to moisture in ambient air could increase the } \\
\text { moderation in the deposit. Since the deposit has } \\
\text { unknown mass distribution, one must assume } \\
\text { worse shape (spherical) with the consequent } \\
\text { possibility for a nuclear criticality event. }\end{array}$ & \multicolumn{2}{|c|}{$\begin{array}{l}\text { As previously stated, neutronic calculations } \\
\text { show that moisture from ambient air will not } \\
\text { cause a criticality without additional events. } \\
\text { Rather than assuming a sphere, equipment } \\
\text { configuration was taken into account to } \\
\text { determine the worst shape possible. Also, one } \\
\text { does not have to assume a spherical shape if } \\
\text { there is no mechanism to form that shape. }\end{array}$} & \\
\hline
\end{tabular}


OAK RIDGE PROGRAM DIVISION DOCUMENT REVIEW FORM

$D=$ Deficiency of some type; cite applicable regulation(s)
$\mathrm{C}=$ Clarification or additional information needed; response may be in summary of comment responses and/or next version of document
$\mathrm{E}=$ Editorial comments will be noted and corrected, but dropped from the summary of comment responses

\begin{tabular}{|c|c|c|c|c|}
\hline $\begin{array}{c}\text { COMMENT } \\
\text { NO. }\end{array}$ & $\begin{array}{l}\text { SECT/ } \\
\text { PAGE }\end{array}$ & COMMENT & RESPONSE & $\begin{array}{l}\text { ACCEPT/ } \\
\text { REJECT }\end{array}$ \\
\hline 5. & Top of page 7 & $\begin{array}{l}\text { Were the cooler voids (i.e., coolant tubes, fins) } \\
\text { modeled as filled with fissile solution or left as } \\
\text { voids? }\end{array}$ & $\begin{array}{l}\text { The coolant tubes were voids for no water } \\
\text { flooding cases and water for water flooding } \\
\text { events. The aluminum fins were modeled in } \\
\text { two ways. The first was to exclude the fins and } \\
\text { the second was to mix aluminum into the } \\
\text { deposit when the deposit region intersects the } \\
\text { fins. }\end{array}$ & \\
\hline 6. & $\begin{array}{l}\text { Page } 7 \text {, bottom } \\
\text { paragraph }\end{array}$ & $\begin{array}{l}\text { "forced flow of } 100 \text { percent relative humidity } \\
\text { air over the deposit." Take out the word } \\
\text { "forced." The flow could be convective. Take } \\
\text { out " } 100 \text { percent." Experiments at } 50 \text { percent } \\
\text { show the same phenomena. (Curtis Jordan will } \\
\text { provide more information here.) }\end{array}$ & $\begin{array}{l}\text { Experiments have shown that good circulation } \\
\text { is required for deliquescence of } \mathrm{UO}_{2} \mathrm{~F}_{2} \text {. During } \\
\text { a conversation with } \mathrm{R} \text {. Gerald Russell, he states } \\
\text { that the air flow required to cause deliquescence } \\
\text { will not occur at the east and west coolers based } \\
\text { upon the shutdown of Building } \mathrm{K}-31 \text {. The } \\
\text { experiments involving } 50 \text { percent relative } \\
\text { humidity demonstrated that } \mathrm{UO}_{2} \mathrm{~F}_{2} \text { did not } \\
\text { deliquesce at } 77^{\circ} \mathrm{F} \text { and is supported by the } \\
\text { report provided by C. Jordan. Deliquescence } \\
\text { was observed for experiments involving } 100 \\
\text { percent relative humidity and good circulation. }\end{array}$ & \\
\hline
\end{tabular}


OAK RIDGE PROGRAM DIVISION DOCUMENT REVIEW FORM

\begin{tabular}{|c|c|c|c|c|c|}
\hline \multicolumn{2}{|c|}{$\begin{array}{l}D=\text { Deficiency of some type; cite } \\
\text { applicable regulation(s) }\end{array}$} & \multicolumn{2}{|c|}{$\begin{array}{l}\mathrm{C}=\text { Clarification or additional information } \\
\text { needed; response may be in summary of comment } \\
\text { responses and/or next version of document }\end{array}$} & \multicolumn{2}{|c|}{$\begin{array}{l}\text { E = Editorial comments will be noted } \\
\text { and corrected, but dropped from the } \\
\text { summary of comment responses }\end{array}$} \\
\hline $\begin{array}{l}\text { COMMENT } \\
\text { NO. }\end{array}$ & $\begin{array}{l}\text { SECT/ } \\
\text { PAGE }\end{array}$ & COMMENT & & RESPONSE & $\begin{array}{l}\text { ACCEPT/ } \\
\text { REJECT }\end{array}$ \\
\hline 7. & & $\begin{array}{l}\text { The present situation assumes the cascade line is } \\
\text { closed and there are no openings. This is } \\
\text { probably true but difficult to demonstrate (e.g., } \\
\text { are the valves completely seated?). It is less } \\
\text { likely that there is liquid present in the process } \\
\text { line in the K-31 Building, where the process } \\
\text { line integrity was maintained, than in the K-25 } \\
\text { Building, where } \sim 13,000 \text { openings were } \\
\text { created. }\end{array}$ & \multicolumn{2}{|c|}{$\begin{array}{l}\text { In Building K-31, the process line integrity has } \\
\text { been maintained. The report will make it clear } \\
\text { that this is assumed. Also, the system } \\
\text { configuration as analyzed will be included. }\end{array}$} & \\
\hline 8. & & $\begin{array}{l}\text { The present condition of the deposits } \\
\text { (moderation level, deposit distribution, etc.) is } \\
\text { merely an assumption that is suitable for best } \\
\text { estimates but not acceptable for safety analyses. } \\
\text { Terms like "more realistic," in the top } \\
\text { paragraph on Page 8, are a bit too strong. } \\
\text { Maybe "best estimate" is better. }\end{array}$ & \multicolumn{2}{|c|}{$\begin{array}{l}\text { This assumption is based on process knowledge, } \\
\text { engineering judgment, experience, and } \\
\text { measurements. (Safety analyses should attempt } \\
\text { to define the risk and show ways for risk } \\
\text { control. To do this one uses every available } \\
\text { tool-including engineering judgment, process } \\
\text { knowledge, experience, and measurements-to } \\
\text { make the best safety analyses possible.) }\end{array}$} & \\
\hline
\end{tabular}


OAK RIDGE PROGRAM DIVISION DOCUMENT REVIEW FORM

\begin{tabular}{|c|c|c|c|c|c|}
\hline \multicolumn{2}{|c|}{$\begin{array}{l}D=\text { Deficiency of some type; cit } \\
\text { applicable regulation(s) }\end{array}$} & \multicolumn{2}{|c|}{$\begin{array}{l}\mathrm{C}=\text { Clarification or additional information } \\
\text { needed; response may be in summary of comment } \\
\text { responses and/or next version of document }\end{array}$} & \multicolumn{2}{|c|}{$\begin{array}{l}\mathrm{E}=\text { Editorial comments will be noted } \\
\text { and corrected, but dropped from the } \\
\text { summary of comment responses }\end{array}$} \\
\hline $\begin{array}{l}\text { COMMENT } \\
\text { NO. }\end{array}$ & $\begin{array}{l}\text { SECT/ } \\
\text { PAGE }\end{array}$ & COMMENT & & RESPONSE & $\begin{array}{l}\text { ACCEPT/ } \\
\text { REJECT }\end{array}$ \\
\hline 9. & $\begin{array}{l}\text { Page } 8 \text {, middle } \\
\text { paragraph }\end{array}$ & $\begin{array}{l}\text { "experienced operators and engineers at the K- } \\
31 \text { facility consider water ingress into the cooler } \\
\text { to be very unlikely, if not impossible (Latham } \\
\text { 1996, Dyer 1996)." Personal communication is } \\
\text { a very weak reference for so strong a statement. } \\
\text { Other equally experienced operators might } \\
\text { disagree. }\end{array}$ & $\begin{array}{l}\text { The statemen } \\
\text { and actual co }\end{array}$ & $\begin{array}{l}\text { as based on process knowledge } \\
\text { guration of the equipment. }\end{array}$ & \\
\hline 10. & & $\begin{array}{l}\text { Do not focus so much on the addition of water } \\
\text { as a moderator. Oils and certain coolants are } \\
\text { also moderators. Access to "liquid" to fissile } \\
\text { material is a better word than "water." What is } \\
\text { the probability of this failing as the equipment } \\
\text { ages? Have the heat exchangers been } \\
\text { completely drained? Consider low points in } \\
\text { lines. }\end{array}$ & $\begin{array}{l}\text { All oil and } \mathrm{c} \\
\text { and the mate } \\
\text { water is the } \\
\text { moderation. } \\
\text { Building } \mathrm{K}-3 \\
\text { equipment in } \\
\text { exchangers } \\
\text { mechanism } \\
\text { remaining in }\end{array}$ & $\begin{array}{l}\text { ant systems have been drained } \\
\text { s removed from the building; } \\
\text { potential source of } \\
\text { impact of equipment aging in } \\
\text { much less significant than for } \\
\text { operating facility. The heat } \\
\text { been drained. There must be a } \\
\text { love any potential liquid } \\
\text { ow point to the deposit. }\end{array}$ & \\
\hline
\end{tabular}




\section{OAK RIDGE PROGRAM DIVISION DOCUMENT REVIEW FORM}

\begin{tabular}{|c|c|c|c|c|c|}
\hline \multicolumn{2}{|c|}{$\begin{array}{l}D=\text { Deficiency of some type; cite } \\
\text { applicable regulation(s) }\end{array}$} & \multicolumn{2}{|c|}{$\begin{array}{l}\mathrm{C}=\text { Clarification or additional information } \\
\text { needed; response may be in summary of comment } \\
\text { responses and/or next version of document }\end{array}$} & \multicolumn{2}{|c|}{$\begin{array}{l}E=\text { Editorial comments will be noted } \\
\text { and corrected, but dropped from the } \\
\text { summary of comment responses }\end{array}$} \\
\hline $\begin{array}{l}\text { COMMENT } \\
\text { NO. }\end{array}$ & $\begin{array}{l}\text { SECT/ } \\
\text { PAGE }\end{array}$ & COMMENT & & RESPONSE & $\begin{array}{l}\text { ACCEPT/ } \\
\text { REJECT }\end{array}$ \\
\hline 11. & & $\begin{array}{l}\text { This fault tree analysis does not consider time- } \\
\text { dependent effects. Equipment and buildings } \\
\text { age. Concrete ceiling panes can fall onto } \\
\text { process equipment, which happened in the K-25 } \\
\text { Building recently. Consider adding a statement } \\
\text { saying that this fault tree analysis is only a } \\
\text { snapshot in time (i.e., it is not time dependent) } \\
\text { and that deposits cannot be stored in process } \\
\text { equipment (e.g., coolers) indefinitely. There is } \\
\text { no substitute for removing the deposit to } \\
\text { eliminate the risk of criticality. }\end{array}$ & $\begin{array}{l}\text { Agree. Rem } \\
\text { all future risk } \\
\text { you determin } \\
\text { Building K-3 } \\
\text { panels. Buil } \\
\text { year, and all } \\
\text { in good cond } \\
\text { operating equ } \\
\text { equipment no } \\
\text { snapshot in ti } \\
\text { significant pe } \\
\text { occur to the }\end{array}$ & $\begin{array}{l}\text { ng the deposits will eliminate } \\
\text { criticality. However, how do } \\
\text { e urgency of the action? } \\
\text { oes not have concrete ceiling } \\
\text { K-31 has been reroofed this } \\
\text { the roof deck was found to be } \\
\text { n. Age has a bigger effect on } \\
\text { nent reliability than it does on } \\
\text { nger operating. Yes, it is a } \\
\text { but it will be valid for a } \\
\text { dunless significant changes } \\
\text { ting conditions. }\end{array}$ & \\
\hline
\end{tabular}




\section{OAK RIDGE PROGRAM DIVISION DOCUMENT REVIEW FORM}

\begin{tabular}{|c|c|c|c|c|c|c|}
\hline \multicolumn{3}{|c|}{$\begin{array}{l}D=\text { Deficiency of some type; cite } \\
\text { applicable regulation(s) }\end{array}$} & \multicolumn{2}{|c|}{$\begin{array}{l}\mathrm{C}=\text { Clarification or additional information } \\
\text { needed; response may be in summary of comment } \\
\text { responses and/or next version of document }\end{array}$} & \multicolumn{2}{|c|}{$\begin{array}{l}\mathrm{E}=\text { Editorial comments will be noted } \\
\text { and corrected, but dropped from the } \\
\text { summary of comment responses }\end{array}$} \\
\hline $\begin{array}{l}\text { COMMENT } \\
\text { NO. }\end{array}$ & $\begin{array}{l}\text { SECT/ } \\
\text { PAGE }\end{array}$ & \multicolumn{2}{|r|}{ COMMENT } & & RESPONSE & $\begin{array}{l}\text { ACCEPT/ } \\
\text { REJECT }\end{array}$ \\
\hline 12. & Page 10 & \multicolumn{2}{|c|}{$\begin{array}{l}\text { I do not agree with this statement that "Neither } \\
\text { deliquescence nor condensation are credible } \\
\text { sources of water for moderation of the deposit } \\
\text { (Kirchner 1993)." This statement, which } \\
\text { appears on page } 43 \text { of report K/D- } 6048 \text {, is taken } \\
\text { out of context. Caveats to this conclusion } \\
\text { appear throughout the K/D-6048 report, among } \\
\text { them the assumption that the system is closed } \\
\text { and airtight. There may be sufficient moisture } \\
\text { from in-leakage of air to provide optimal } \\
\text { moderation for the deposits. Note that the } \\
\text { deposit is optimally moderated when it appears } \\
\text { that the deposit is dry (H/U < } 16 \text { ). The } \\
\text { material system does not have to be a liquid to } \\
\text { be critical. }\end{array}$} & \multicolumn{2}{|c|}{$\begin{array}{l}\text { Kirchner's conclusion is correct for Building K- } \\
31 \text {. Per conversation with R. Kirchner, he } \\
\text { concurs with our interpretation of the } \\
\text { referenced passage. Neutronic calculation } \\
\text { showed that deliquescence will not result in a } \\
\text { criticality in the K-31 coolers without additional } \\
\text { events occurring (see response to Comments } 1 \\
\text { and } 6 \text { ). }\end{array}$} & \\
\hline 13. & & \multicolumn{2}{|c|}{$\begin{array}{l}\text { The building does not have to be flooded to } \\
\text { provide deposit reflection. Some process } \\
\text { equipment is sufficiently large in size that there } \\
\text { could be internal reflection if the equipment is } \\
\text { deluged with liquid. }\end{array}$} & \multicolumn{2}{|c|}{$\begin{array}{l}\text { Based on the condition of the facility and the } \\
\text { configuration of the equipment, the probability } \\
\text { that the equipment could be deluged with liquid } \\
\text { is not significant (new roof, fire system dry and } \\
\text { monitored } 24 \text { hours/day, cooling water drained } \\
\text { and lines blanked, cell housing around } \\
\text { equipment). }\end{array}$} & \\
\hline \multicolumn{3}{|c|}{ REVIEWED BY: M. J. Haire } & & \multicolumn{3}{|c|}{ RESPONSE BY: D. Morgan, L. Paschal, D. Reed } \\
\hline
\end{tabular}




\section{OAK RIDGE PROGRAM DIVISION DOCUMENT REVIEW FORM}

\begin{tabular}{|c|c|c|c|c|c|}
\hline \multicolumn{2}{|c|}{$\begin{array}{l}D=\text { Deficiency of some type; cite } \\
\text { applicable regulation(s) }\end{array}$} & \multicolumn{2}{|c|}{$\begin{array}{l}\mathrm{C}=\text { Clarification or additional information } \\
\text { needed; response may be in summary of comment } \\
\text { responses and/or next version of document }\end{array}$} & \multicolumn{2}{|c|}{$\begin{array}{l}\mathrm{E}=\text { Editorial comments will be noted } \\
\text { and corrected, but dropped from the } \\
\text { summary of comment responses }\end{array}$} \\
\hline $\begin{array}{l}\text { COMMENT } \\
\text { NO. }\end{array}$ & $\begin{array}{l}\text { SECT/ } \\
\text { PAGE }\end{array}$ & COMMENT & & RESPONSE & $\begin{array}{l}\text { ACCEPT/ } \\
\text { REJECT }\end{array}$ \\
\hline 14. & Page 11, top line & $\begin{array}{l}\text { "The only large inventory of combustible } \\
\text { material in Building K-31 was the compressor } \\
\text { lube oil." This does not take into account the } \\
\text { tar roof. Paducah had a roof fire several years } \\
\text { ago that caused great concern. Of course, if the } \\
\text { building is leased, or subcontractors start using } \\
\text { the building, there will likely be combustible } \\
\text { material brought in. Add this as part of your } \\
\text { documented present conditions (controls). }\end{array}$ & \multicolumn{2}{|c|}{$\begin{array}{l}\text { The Paducah roof fire was the result of ignition } \\
\text { of a lube oil spill on the roof and not the result } \\
\text { of the roof membrane igniting. The lube oil in } \\
\text { Building K-31 has been removed. If the } \\
\text { building is leased, the introduction of } \\
\text { combustible materials will be evaluated at that } \\
\text { time. }\end{array}$} & \\
\hline 15. & $\begin{array}{l}\text { Page } 11 \text {, Sect. } \\
2.2 .1 \text {, Ist } \\
\text { sentence }\end{array}$ & $\begin{array}{l}\text { As noted earlier, I disagree with this statement } \\
\text { that the fault tree analysis indicates "that the } \\
\text { probability of the failure to prevent conditions } \\
\text { favorable for a criticality in the west cooler is } 2 \\
\times 10^{-9} \text {." }\end{array}$ & \multicolumn{2}{|c|}{$\begin{array}{l}\text { The fault tree analysis has been revised to } \\
\text { reflect the probability of failure to prevent } \\
\text { water ingress into the coolers. The analysis } \\
\text { supports the conclusion that flooding of the } \\
\text { cooler is not a credible event. The value for } \\
\text { the fault tree will not be used as an absolute } \\
\text { value. }\end{array}$} & \\
\hline
\end{tabular}


OAK RIDGE PROGRAM DIVISION DOCUMENT REVIEW FORM

$\mathrm{D}=$ Deficiency of some type; cite applicable regulation(s)
$\mathrm{C}=$ Clarification or additional information needed; response may be in summary of comment responses and/or next version of document
$\mathrm{E}=$ Editorial comments will be noted and corrected, but dropped from the summary of comment responses

\begin{tabular}{|c|c|c|c|c|}
\hline $\begin{array}{l}\text { COMMENT } \\
\text { NO. }\end{array}$ & $\begin{array}{l}\text { SECT/ } \\
\text { PAGE }\end{array}$ & COMMENT & RESPONSE & $\begin{array}{l}\text { ACCEPT/ } \\
\text { REJECT }\end{array}$ \\
\hline 16. & $\begin{array}{l}\text { Page 13, Chap. } \\
3\end{array}$ & $\begin{array}{l}\text { Combining neutronic and probabilistic } \\
\text { methodologies is one approach, but it may not } \\
\text { be "excellent," as noted in the above discussion. } \\
\text { As also noted above, I disagree that the double } \\
\text { contingency principle is met. }\end{array}$ & $\begin{array}{l}\text { Agree. Will remove the word excellent. } \\
\text { Remaining subcritical is the important factor, } \\
\text { and the neutronic calculations show that the } \\
\text { coolers are subcritical for normal and credible } \\
\text { abnormal conditions. In addition, we maintain } \\
\text { that the double contingency principle is satisfied } \\
\text { based on DOE Order } 5480.24 \text {. }\end{array}$ & \\
\hline 17. & $\begin{array}{l}\text { Chap. 4, first } \\
\text { sentence }\end{array}$ & $\begin{array}{l}\text { I believe that the sentence, "The coolers must } \\
\text { be maintained in their current state for the } \\
\text { assumptions in this analysis to be valid," should } \\
\text { be emphasized more. I suggest that you } \\
\text { tabulate the assumptions (controls) key to this } \\
\text { analysis. }\end{array}$ & $\begin{array}{l}\text { The report will be revised to incorporate the } \\
\text { assumptions that were used for the analysis. }\end{array}$ & \\
\hline 18. & Chap. 5 & $\begin{array}{l}\text { The DRP generally follows the } \\
\text { recommendations given in Chapter } 5 \text {. } \\
\text { Limitations of funding, availability of skilled } \\
\text { experts, and time limit our use of probabilistic } \\
\text { analyses. }\end{array}$ & $\begin{array}{l}\text { Using this approach as a management tool may } \\
\text { facilitate a reduction in the number of deposits } \\
\text { requiring removal. This approach may be more } \\
\text { cost-effective than removing each of the } \\
\text { deposits. }\end{array}$ & \\
\hline
\end{tabular}


OAK RIDGE PROGRAM DIVISION DOCUMENT REVIEW FORM

\begin{tabular}{|c|c|c|c|c|c|}
\hline \multicolumn{2}{|c|}{$\begin{array}{l}\mathrm{D}=\text { Deficiency of some type; cite } \\
\text { applicable regulation(s) }\end{array}$} & \multicolumn{2}{|c|}{$\begin{array}{l}\mathrm{C}=\text { Clarification or additional information } \\
\text { needed; response may be in summary of comment } \\
\text { responses and/or next version of document }\end{array}$} & \multicolumn{2}{|c|}{$\begin{array}{l}\mathrm{E}=\text { Editorial comments will be noted } \\
\text { and corrected, but dropped from the } \\
\text { summary of comment responses }\end{array}$} \\
\hline $\begin{array}{l}\text { COMMENT } \\
\text { NO. }\end{array}$ & $\begin{array}{l}\text { SECT/ } \\
\text { PAGE }\end{array}$ & COMMENT & & RESPONSE & $\begin{array}{l}\text { ACCEPT/ } \\
\text { REJECT }\end{array}$ \\
\hline 19. & & $\begin{array}{l}\text { Regarding the fault tree, block valves were } \\
\text { notorious for their leaking during operation and, } \\
\text { thus, their failure rate must be substantially } \\
\text { higher than } 5 \times 10^{-8} / \text { hour used. This value is } \\
\text { probably for a new, modern valve maintained in } \\
\text { perfect working condition. The } \mathrm{K}-25 \text { Gaseous } \\
\text { Diffusion Plant valves had no formal } \\
\text { maintenance program and were exposed to a } \\
\text { corrosive fluoride gas (UF, There is no } \\
\text { compelling reason to believe that the valves will } \\
\text { contain or hold back water. The failure rates } \\
\text { for blocking valves may need to be reexamined. }\end{array}$ & \multicolumn{2}{|c|}{$\begin{array}{l}\text { The failure rates are from the generic } \\
\text { component failure rate database for light water } \\
\text { and sodium reactor PRAs developed by INEL. } \\
\text { The data are NOT for new components. The } \\
\text { data are based on input from various sources } \\
\text { including commercial plant PRAs and WASH- } \\
1400 \text {. }\end{array}$} & \\
\hline 20. & General & $\begin{array}{l}\text { The title of the report does not reflect what was } \\
\text { done. The report did not evaluate the K-25 } \\
\text { Site, just two coolers in the K-31 Building. }\end{array}$ & \multicolumn{2}{|c|}{ Agree. The title has been revised. } & \\
\hline
\end{tabular}




\section{OAK RIDGE PROGRAM DIVISION DOCUMENT REVIEW FORM}

DOCUMENT TITLE: Independent Evaluation of Criticality Issues Associated with Uranium Deposits at the

K-25 Site, Oak Ridge, Tennessee

DATE COMMENTS

ARE DUE:

DOCUMENT NUMBER:

\begin{tabular}{|l|l|}
\hline NAME OF REVIEWER: W. C. Jordan & $\begin{array}{l}\text { ORGANIZATION: Lockheed Martin } \\
\text { Energy Systems }\end{array}$ \\
\hline DATE COMMENTS TRANSMITTED: & \\
\hline
\end{tabular}

\section{COMMENT CODE}

$\mathrm{C}=$ Clarification or additional information needed; response may be in summary of comment responses and/or next version of document
$\mathbf{E}=$ Editorial comments will be noted and corrected, but dropped from the summary of comment responses

\begin{tabular}{|c|c|c|c|c||}
\hline $\begin{array}{c}\text { COMMENT } \\
\text { NO. }\end{array}$ & $\begin{array}{l}\text { SECT/ } \\
\text { PAGE }\end{array}$ & COMMENT & RESPONSE & $\begin{array}{c}\text { ACCEPT/ } \\
\text { REJECT }\end{array}$ \\
\hline 1. & & $\begin{array}{l}\text { I disagree with your conclusion that moderation } \\
\text { by exposure to ambient air (and subsequent } \\
\text { deliquescence of the deposit) is not credible. }\end{array}$ & $\begin{array}{l}\text { The conclusion is based on the configuration of the } \\
\text { coolers and the lack of ability for ambient air to } \\
\text { have good circulation. This conclusion is shared }\end{array}$ & \\
\hline
\end{tabular}


OAK RIDGE PROGRAM DIVISION DOCUMENT REVIEW FORM

\begin{tabular}{|c|c|c|c|c|c|c|}
\hline \multicolumn{3}{|c|}{$\begin{array}{l}\mathrm{D}=\text { Deficiency of some type; cite } \\
\text { applicable regulation(s) }\end{array}$} & \multicolumn{2}{|c|}{$\begin{array}{l}\mathrm{C}=\text { Clarification or additional information } \\
\text { needed; response may be in summary of comment } \\
\text { responses and/or next version of document }\end{array}$} & \multicolumn{2}{|c|}{$\begin{array}{l}\mathrm{E}=\text { Editorial comments will be noted } \\
\text { and corrected, but dropped from the } \\
\text { summary of comment responses }\end{array}$} \\
\hline \multirow[t]{2}{*}{$\begin{array}{l}\text { COMMENT } \\
\text { NO. }\end{array}$} & $\begin{array}{l}\text { SECT/ } \\
\text { PAGE }\end{array}$ & & COMMENT & \multicolumn{2}{|c|}{ RESPONSE } & $\begin{array}{l}\text { ACCEPT/ } \\
\text { REJECT }\end{array}$ \\
\hline & & & & \multicolumn{2}{|c|}{$\begin{array}{l}\text { with Kirchner who also states "it is concluded that } \\
\text { neither deliquescence nor condensation of water } \\
\text { vapor on internal equipment surfaces is a credible } \\
\text { potential cause of nuclear criticality in the LEU } \\
\text { facilities." The neutronic calculations support this } \\
\text { conclusion, because optimal moderation alone will } \\
\text { not cause a criticality. During telephone } \\
\text { conversations, } R \text {. G. Russell agrees that more than } \\
\text { exposure to ambient air is needed for a criticality to } \\
\text { occur. }\end{array}$} & \\
\hline 2. & Page 7 & $\begin{array}{l}\text { Your } \\
\text { condi } \\
\text { depos } \\
\text { does } \\
\text { water } \\
\mathrm{UO}_{2} \mathrm{~F} \\
\text { and } \\
\text { that } \mathrm{r} \\
\text { samp }\end{array}$ & $\begin{array}{l}\text { t that Russell recognizes only two } \\
\text { could lead to moderation of the } \\
\text { rrect and misleading. Russell } \\
\text { nt a discussion of flooding with } \\
\text { I performed experiments within } \\
\text { es at various moisture contents } \\
\text { es and documented conditions } \\
\text { water weight changes in the }\end{array}$ & \multicolumn{2}{|c|}{$\begin{array}{l}\text { The statement is being modified to represent the } \\
\text { intent of Russell's experiments. This modification } \\
\text { will be based on Russell's paper and telephone } \\
\text { conversations with him. See response to M. J. } \\
\text { Haire, Comment } 6 \text {. }\end{array}$} & \\
\hline
\end{tabular}

\begin{tabular}{|l|l|}
\hline REVIEWED BY: W. C. Jordan & RESPONSE BY: D. Morgan, L. Paschal, D. Reed \\
\hline \multirow{2}{*}{$\frac{8}{8}$} & R. P. \\
\hline
\end{tabular}




\section{OAK RIDGE PROGRAM DIVISION DOCUMENT REVIEW FORM}

\begin{tabular}{|c|c|c|c|c|c|c|}
\hline \multicolumn{3}{|c|}{$\begin{array}{l}\mathrm{D}=\text { Deficiency of some type; cite } \\
\text { applicable regulation(s) }\end{array}$} & \multicolumn{2}{|c|}{$\begin{array}{l}\mathrm{C}=\text { Clarification or additional information } \\
\text { needed; response may be in summary of comment } \\
\text { responses and/or next version of document }\end{array}$} & \multicolumn{2}{|c|}{$\begin{array}{l}\mathrm{E}=\text { Editorial comments will be noted } \\
\text { and corrected, but dropped from the } \\
\text { summary of comment responses }\end{array}$} \\
\hline $\begin{array}{c}\text { COMMENT } \\
\text { NO. }\end{array}$ & $\begin{array}{l}\text { SECT/ } \\
\text { PAGE }\end{array}$ & & COMMENT & \multicolumn{2}{|c|}{ RESPONSE } & $\begin{array}{c}\text { ACCEPT/ } \\
\text { REJECT }\end{array}$ \\
\hline 3. & & $\begin{array}{l}\text { Your } \\
\text { relati } \\
\text { occur } \\
\text { humic } \\
\text { be ex } \\
\text { occur } \\
\text { satura } \\
\mathrm{UO}_{2} \mathrm{~F} \\
\text { soluti }\end{array}$ & $\begin{array}{l}\text { th that a forced flow of air at } 100 \% \\
\text { ity is required for deliquescence to } \\
\text { ncorrect and misleading. Russell's } \\
\text { showed that the } \mathrm{UO}_{2} \mathrm{~F}_{2} \text { only need } \\
\text { humid air for deliquescence to } \\
\text { conclusions, he states that “...in a } \\
\text { sphere with good circulation, the } \\
\text { b enough moisture to form a } \\
\text { everal hours is required." }\end{array}$ & \multicolumn{2}{|c|}{$\begin{array}{l}\text { The identified quote was discussed with Russell. } \\
\text { Per that conversation, good circulation in the deposit } \\
\text { environment requires some type of forced flow of } \\
\text { humid air or the proximity of the deposit to a liquid } \\
\text { source of water having a large surface area, such } \\
\text { that natural circulation causes good diffusion of } \\
\text { water vapor to the deposit. Russell also stated that } \\
\text { the condition would not exist in the environment of a } \\
\text { shut-down gaseous diffusion plant. }\end{array}$} & \\
\hline
\end{tabular}




\section{OAK RIDGE PROGRAM DIVISION DOCUMENT REVIEW FORM}

\begin{tabular}{|c|c|c|c|c|c|c|}
\hline \multicolumn{3}{|c|}{$\begin{array}{l}\mathrm{D}=\text { Deficiency of some type; cite } \\
\text { applicable regulation(s) }\end{array}$} & \multicolumn{2}{|c|}{$\begin{array}{l}\mathrm{C}=\text { Clarification or additional information } \\
\text { needed; response may be in summary of comment } \\
\text { responses and/or next version of document }\end{array}$} & \multicolumn{2}{|c|}{$\begin{array}{l}\text { E = Editorial comments will be noted } \\
\text { and corrected, but dropped from the } \\
\text { summary of comment responses. }\end{array}$} \\
\hline $\begin{array}{l}\text { COMMENT } \\
\text { NO. }\end{array}$ & $\begin{array}{l}\text { SECT/ } \\
\text { PAGE }\end{array}$ & & COMMENT & \multicolumn{2}{|c|}{ RESPONSE } & $\begin{array}{l}\text { ACCEPT } / \\
\text { REJECT }\end{array}$ \\
\hline 4. & & $\begin{array}{l}\text { Additi } \\
\text { Fluori } \\
\text { G. Ru } \\
\text { (Ref } 1 \\
\text { involv } \\
\text { pheno } \\
\text { water } \\
\text { Gener } \\
\text { is ma } \\
\text { hydra } \\
\text { moles } \\
\text { partia } \\
\text { of } 12 \\
\text { Russe } \\
\text { pressi } \\
25^{\circ} \mathrm{C} \text { ) }\end{array}$ & $\begin{array}{l}\text { y of Russell's results, Uranyl } \\
\text { s Hydrates, J. M. Leitnaker, R. } \\
\text { E.J. Barber, unpublished draft } \\
\text { ses the details of the physics } \\
\text { iquescence and indicates that the } \\
\text { related to the partial pressure of } \\
\text { Under the section "Some } \\
\text { lerations" in Ref. 1, the statement } \\
\text { ell's data indicate that the } \\
\text { not exceed the nominal two } \\
\text { per mole of } \mathrm{UO}_{2} \mathrm{~F}_{2} \text { unless the } \\
\text { [of water] exceeds a minimum } \\
\text { relative humidity) at } 25^{\circ} \mathrm{C} . \text { " } \\
\text { d deliquescence at a partial } \\
\text { torr (100\% relative humidity @ }\end{array}$ & \multicolumn{2}{|c|}{$\begin{array}{l}\text { Concur. Text is being modified to discuss partial } \\
\text { pressures and include Table } 1 .\end{array}$} & \\
\hline 5. & & $\begin{array}{l}\text { Any e } \\
\text { result: } \\
\text { coolet } \\
\text { moder }\end{array}$ & $\begin{array}{l}\text { dministrative control failure that } \\
\text { path for ambient air around the } \\
\text { can result in significant } \\
\text { he deposit. }\end{array}$ & \multicolumn{2}{|c|}{$\begin{array}{l}\text { Russell stated during telephone conversations that, if } \\
\text { the cooler was removed from the system, left open, } \\
\text { and placed outside, deliquescence would not occur, } \\
\text { provided a liquid source of water (i.e., rain water) is } \\
\text { precluded. }\end{array}$} & \\
\hline
\end{tabular}


OAK RIDGE PROGRAM DIVISION DOCUMENT REVIEW FORM

\begin{tabular}{|c|c|c|c|c|c|c|}
\hline \multicolumn{3}{|c|}{$\begin{array}{l}D=\text { Deficiency of some type; cite } \\
\text { applicable regulation(s) }\end{array}$} & \multicolumn{2}{|c|}{$\begin{array}{l}\mathrm{C}=\text { Clarification or additional information } \\
\text { needed; response may be in summary of comment } \\
\text { responses and/or next version of document }\end{array}$} & \multicolumn{2}{|c|}{$\begin{array}{l}\mathrm{E}=\text { Editorial comments will be noted } \\
\text { and corrected, but dropped from the } \\
\text { summary of comment responses }\end{array}$} \\
\hline $\begin{array}{l}\text { COMMENT } \\
\text { NO. }\end{array}$ & $\begin{array}{l}\text { SECT/ } \\
\text { PAGE }\end{array}$ & & COMMENT & \multicolumn{2}{|c|}{ RESPONSE } & $\begin{array}{l}\text { ACCEPT/ } \\
\text { REJECT }\end{array}$ \\
\hline 6. & & $\begin{array}{l}\text { It shou } \\
\text { uraniu } \\
\text { for mi } \\
\mathrm{H} / \mathrm{U}= \\
\mathrm{H} / \mathrm{U}= \\
\text { moder } \\
\text { minim } \\
\text { where } \\
\text { appear }\end{array}$ & $\begin{array}{l}\text { ted that for } 3.3 \% \text { enriched } \\
\mathrm{H} / \mathrm{X}=460 \text { (optimum moderation } \\
\text { lass criticality), the corresponding } \\
\text { irated } \mathrm{UO}_{2} \mathrm{~F}_{2} \text { solution has an } \\
\text { indicates that optimum } \\
\text { both minimum mass and } \\
\text { letry criticality) occur in a range } \\
\text { sit is not in solution and may }\end{array}$ & \multicolumn{2}{|l|}{ Noted. } & \\
\hline 7. & & \multicolumn{2}{|c|}{$\begin{array}{l}\text { Virtually any deposit geometry could be realized } \\
\text { inside the large geometry cooler if the deposit is } \\
\text { moderated by exposure to ambient air. }\end{array}$} & \multicolumn{2}{|c|}{$\begin{array}{l}\text { The geometry of the material depends on the internal } \\
\text { structure of the equipment, because the dry deposit } \\
\text { will attach itself to internal structures. If optimal } \\
\text { moderation is reached, the deposit will either } \\
\text { maintain its current location or move to a new } \\
\text { location due to the influence of gravity. }\end{array}$} & \\
\hline
\end{tabular}


OAK RIDGE PROGRAM DIVISION DOCUMENT REVIEW FORM

\begin{tabular}{|c|c|c|c|c|c|c|}
\hline \multicolumn{3}{|c|}{$\begin{array}{l}D=\text { Deficiency of some type; cite } \\
\text { applicable regulation(s) }\end{array}$} & \multicolumn{2}{|c|}{$\begin{array}{l}\mathrm{C}=\text { Clarification or additional information } \\
\text { needed; response may be in summary of comment } \\
\text { responses and/or next version of document }\end{array}$} & \multicolumn{2}{|c|}{$\begin{array}{l}\text { E = Editorial comments will be noted } \\
\text { and corrected, but dropped from the } \\
\text { summary of comment responses }\end{array}$} \\
\hline $\begin{array}{c}\text { COMMENT } \\
\text { NO. }\end{array}$ & $\begin{array}{l}\text { SECT/ } \\
\text { PAGE }\end{array}$ & & COMMENT & \multicolumn{2}{|c|}{ RESPONSE } & $\begin{array}{l}\text { ACCEPT/ } \\
\text { REJECT }\end{array}$ \\
\hline 8. & & $\begin{array}{l}\text { The e } \\
\text { equipt } \\
\text { events } \\
\text { the eq } \\
\text { made } \\
\text { becon } \\
\text { the ev } \\
\text { contro } \\
\text { that th } \\
\text { buildi } \\
\text { evalue }\end{array}$ & $\begin{array}{l}\text { discussed passive failures of } \\
\text { assigned probabilities of these } \\
\text { luipment and the configuration of } \\
\text { ppon which the evaluation was } \\
\text { pecified. This configuration } \\
t \text { of criticality controls that make } \\
\text { icceptable. No administrative } \\
\text { were evaluated. This implies } \\
\text { no human activity in the } \\
\text { could have an impact on the } \\
\text { guration. }\end{array}$ & \multicolumn{2}{|c|}{$\begin{array}{l}\text { Refer to Response 2a under M. J. Haire's } \\
\text { comments. }\end{array}$} & \\
\hline 9. & & \multicolumn{2}{|c|}{$\begin{array}{l}\text { Conditions that do not appear to be analyzed } \\
\text { include the fact that the diffusion equipment was } \\
\text { operated with RCW/R-114 heat exchangers and } \\
\text { PG coolers that leaked. The probabilities used } \\
\text { do not appear to reflect equipment that has } \\
\text { already failed. }\end{array}$} & \multicolumn{2}{|c|}{$\begin{array}{l}\text { Refer to Response } 2 b \text { under M. J. Haire's } \\
\text { comments. }\end{array}$} & \\
\hline
\end{tabular}


OAK RIDGE PROGRAM DIVISION DOCUMENT REVIEW FORM

\begin{tabular}{|c|c|c|c|c|c|c|}
\hline \multicolumn{3}{|c|}{$\begin{array}{l}\mathrm{D}=\text { Deficiency of some type; cite } \\
\text { applicable regulation(s) }\end{array}$} & \multicolumn{2}{|c|}{$\begin{array}{l}\mathrm{C}=\text { Clarification or additional information } \\
\text { needed; response may be in summary of comment } \\
\text { responses and/or next version of document }\end{array}$} & \multicolumn{2}{|c|}{$\begin{array}{l}E=\text { Editorial comments will be noted } \\
\text { and corrected, but dropped from the } \\
\text { summary of comment responses }\end{array}$} \\
\hline $\begin{array}{l}\text { COMMENT } \\
\text { NO. }\end{array}$ & $\begin{array}{l}\text { SECT/ } \\
\text { PAGE }\end{array}$ & & COMMENT & \multicolumn{2}{|c|}{ RESPONSE } & $\begin{array}{l}\text { ACCEPT/ } \\
\text { REJECT }\end{array}$ \\
\hline 10. & & $\begin{array}{l}\text { Block } \\
\text { know } \\
\text { maint } \\
\text { were } \\
\text { perioc }\end{array}$ & $\begin{array}{l}\text { the RCW system were also } \\
\text { There was no formal } \\
\text { ogram for these valves, and they } \\
\text { cised a few times over a } 40 \text {-year }\end{array}$ & \multicolumn{2}{|c|}{$\begin{array}{l}\text { The RCW block valves are not of concern. The } \\
\text { block valves in the fault tree refer to those in the } \\
\text { process system. Refer to Response } 19 \text { under M. J. } \\
\text { Haire's comments for discussion concerning process } \\
\text { system block valves. }\end{array}$} & \\
\hline 11. & & \multicolumn{2}{|c|}{$\begin{array}{l}\text { When deposits were suspected in a shut-down } \\
\text { converter or cooler, NCS required that the heat } \\
\text { exchangers be drained, and a tattletale valve on } \\
\text { the heat exchanger be left open so that any } \\
\text { water that leaked to the heat exchanger drained } \\
\text { out. }\end{array}$} & \multicolumn{2}{|c|}{ Noted. Clarification of comment requested. } & \\
\hline 12. & & \multicolumn{2}{|c|}{$\begin{array}{l}\text { Another control that was used for equipment } \\
\text { suspected of containing deposits was a } \\
\text { requirement that the equipment be buffered with } \\
\text { nitrogen or dry air to prevent absorption of } \\
\text { atmospheric moisture. }\end{array}$} & \multicolumn{2}{|c|}{$\begin{array}{l}\text { Nitrogen was introduced as a buffer but may or may } \\
\text { not have leaked from the system over the years. See } \\
\text { Responses } 1-5 \text { for discussion concerning the impact } \\
\text { of atmospheric moisture. }\end{array}$} & \\
\hline
\end{tabular}




\begin{tabular}{|c|c|c|c|c|c|c|}
\hline \multicolumn{3}{|c|}{$\begin{array}{l}D=\text { Deficiency of some type; cite } \\
\text { applicable regulation(s) }\end{array}$} & \multicolumn{2}{|c|}{$\begin{array}{l}\mathrm{C}=\text { Clarification or additional information } \\
\text { needed; response may be in summary of comment } \\
\text { responses and/or next version of document }\end{array}$} & \multicolumn{2}{|c|}{$\begin{array}{l}\mathrm{E}=\text { Editorial comments will be noted } \\
\text { and corrected, but dropped from the } \\
\text { summary of comment responses }\end{array}$} \\
\hline $\begin{array}{l}\text { COMMENT } \\
\text { NO. }\end{array}$ & $\begin{array}{l}\text { SECT } / \\
\text { PAGE }\end{array}$ & & COMMENT & \multicolumn{2}{|c|}{ RESPONSE } & $\begin{array}{l}\text { ACCEPT/ } \\
\text { REJECT }\end{array}$ \\
\hline 13. & & \multicolumn{2}{|c|}{$\begin{array}{l}\text { The configuration of the RCW system and the } \\
\text { sanitary sewer system is of particular } \\
\text { significance relative to the probability of getting } \\
\text { water into the PG system. This includes } \\
\text { whether or not the RCW system still contains } \\
\text { water in the headers and heat exchangers in the } \\
\text { building. }\end{array}$} & \multicolumn{2}{|c|}{$\begin{array}{l}\text { The RCW system has been drained, and the interior } \\
\text { valving has been replaced with blank spacers. In } \\
\text { addition, the RCW supply pumps have been } \\
\text { removed as part of the cooling tower removal } \\
\text { project. }\end{array}$} & \\
\hline 14. & & \multicolumn{2}{|c|}{$\begin{array}{l}\text { One path that does not appear to have been } \\
\text { addressed is water entry through the seal exhaust } \\
\text { system. Some of the seal exhaust pumps were } \\
\text { converted over to use sanitary water as opposed } \\
\text { to using RCW for cooling. The status of the } \\
\text { sanitary water system and any interconnections } \\
\text { to the PG auxiliary systems should be evaluated. } \\
\text { The pumps that continued to use RCW were } \\
\text { hard plumbed to both the supply and return. A } \\
\text { failure in the seal exhaust pump coolant wall } \\
\text { (such as from corrosion or freezing) could open } \\
\text { a path for water to the PG system through the } \\
\text { seals. }\end{array}$} & \multicolumn{2}{|c|}{$\begin{array}{l}\text { Per discussions with Bobby Latham, RCW and/or } \\
\text { sanitary water was used to cool the seal exhaust } \\
\text { pumps. However, the cooling water was not used to } \\
\text { cool the seal exhaust gas. There is no connection } \\
\text { between the seal exhaust system and the pumps' } \\
\text { cooling water. Therefore, water reaching the } \\
\text { deposit in the process cooler is not possible. Also, } \\
\text { the RCW is no longer in service and does not } \\
\text { physically have the connections to provide a path for } \\
\text { any water to the seal exhaust pumps. If sanitary } \\
\text { water is still available to the pumps, it has been } \\
\text { valved out and is no longer in service. }\end{array}$} & \\
\hline
\end{tabular}


OAK RIDGE PROGRAM DIVISION DOCUMENT REVIEW FORM

\begin{tabular}{|c|c|c|c|c|c|c|}
\hline \multicolumn{3}{|c|}{$\begin{array}{l}D=\text { Deficiency of some type; cite } \\
\text { applicable regulation(s) }\end{array}$} & \multicolumn{2}{|c|}{$\begin{array}{l}\mathrm{C}=\text { Clarification or additional information } \\
\text { needed; response may be in summary of comment } \\
\text { responses and/or next version of document }\end{array}$} & \multicolumn{2}{|c|}{$\begin{array}{l}\mathrm{E}=\text { Editorial comments will be noted } \\
\text { and corrected, but dropped from the } \\
\text { summary of comment responses }\end{array}$} \\
\hline $\begin{array}{l}\text { COMMENT } \\
\text { NO. }\end{array}$ & $\begin{array}{l}\text { SECT/ } \\
\text { PAGE }\end{array}$ & & COMMENT & \multicolumn{2}{|c|}{ RESPONSE } & $\begin{array}{l}\text { ACCEPT/ } \\
\text { REJECT }\end{array}$ \\
\hline 15. & & $\begin{array}{l}\text { The b } \\
\text { coole } \\
\text { their } \\
\text { config } \\
\text { equip } \\
\text { place } \\
\text { contr } \\
\text { preve } \\
\text { openi } \\
\text { could } \\
\text { possit } \\
\text { place }\end{array}$ & $\begin{array}{l}\text { is that NCS agrees that the } \\
\text { bably acceptably subcritical in } \\
\text { nfiguration. Because the } \\
\text { important to the safety of the } \\
\text { ninistrative controls must be in } \\
\text { t any change. Moderation } \\
\text { ingle control in place that } \\
\text { lity. Since the single event of } \\
\text { uipment to atmospheric air flow } \\
\text { conditions where criticality is } \\
\text { ple controls or barriers must be in } \\
\text { it this occurrence. }\end{array}$ & \multicolumn{2}{|c|}{$\begin{array}{l}\text { A single event such as described in Comment } 15 \\
\text { may allow for deliquescence, but it will not cause a } \\
\text { nuclear criticality in the east or west cooler deposit } \\
\text { without the addition of water reflection. In addition, } \\
\text { see Responses } 1-5 \text { concerning the issue of } \\
\text { deliquescence. }\end{array}$} & \\
\hline
\end{tabular}


OAK RIDGE PROGRAM DIVISION DOCUMENT REVIEW FORM

DOCUMENT TITLE: Independent Evaluation of Criticality Issues Associated with Uranium Deposits at the K-25 Site, Oak Ridge, Tennessee

DATE COMMENTS ARE DUE:

\section{DOCUMENT NUMBER:}

\begin{tabular}{|l|l|}
\hline \hline NAME OF REVIEWER: T. P. McLaughlin & $\begin{array}{l}\text { ORGANIZATION: Los Alamos } \\
\text { National Laboratory }\end{array}$ \\
\hline DATE COMMENTS TRANSMITTED: & \\
\hline
\end{tabular}

\section{COMMENT CODE}

D = Deficiency of some type;

N $\quad$ cite applicable regulation(s)
$\mathrm{C}=$ Clarification or additional information needed; response may be in summary of comment responses and/or next version of document
$\mathrm{E}=$ Editorial comments will be noted and corrected, but dropped from the summary of comment responses

\begin{tabular}{|c|c|c|c|c|}
\hline $\begin{array}{c}\text { COMMENT } \\
\text { NO. }\end{array}$ & $\begin{array}{c}\text { SECT/ } \\
\text { PAGE }\end{array}$ & COMMENT & RESPONSE & $\begin{array}{c}\text { ACCEPT/ } \\
\text { REJECT }\end{array}$ \\
\hline 1. & Sect. 1.3 & $\begin{array}{l}\text { The discussion of the regulatory requirements is } \\
\text { well stated and puts the Double Contingency } \\
\text { Principle (DCP) in proper perspective. However, }\end{array}$ & $\begin{array}{l}\text { Discussion throughout the paper will be added } \\
\text { to address the issue of Section 4.1.2 from } \\
\text { ANSI/ANS-8.1. }\end{array}$ & \\
\hline
\end{tabular}

REVIEWED BY: T. P. McLaughlin

RESPONSE BY: D. Morgan, L. Paschal, D. Reed 
OAK RIDGE PROGRAM DIVISION DOCUMENT REVIEW FORM

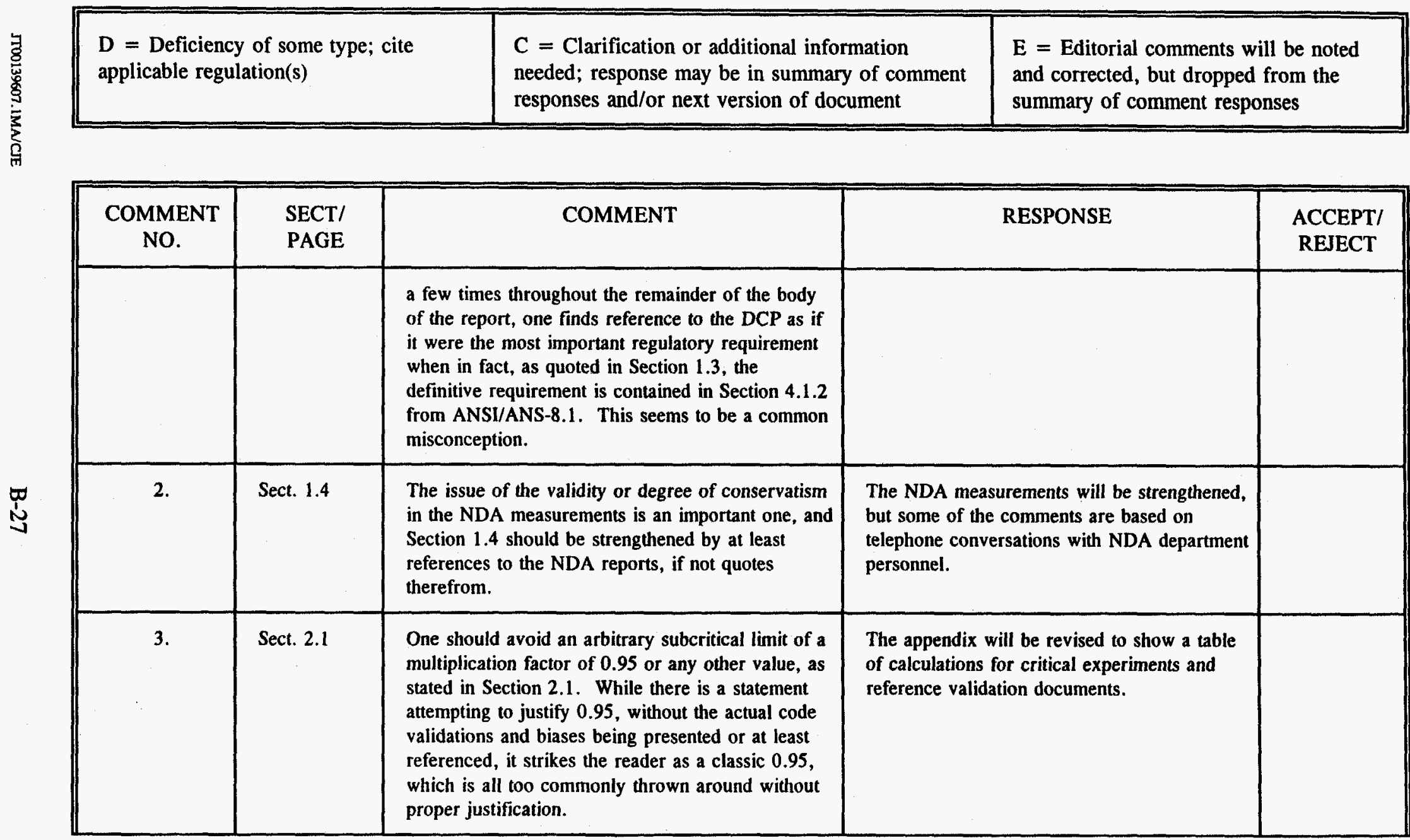


OAK RIDGE PROGRAM DIVISION DOCUMENT REVIEW FORM

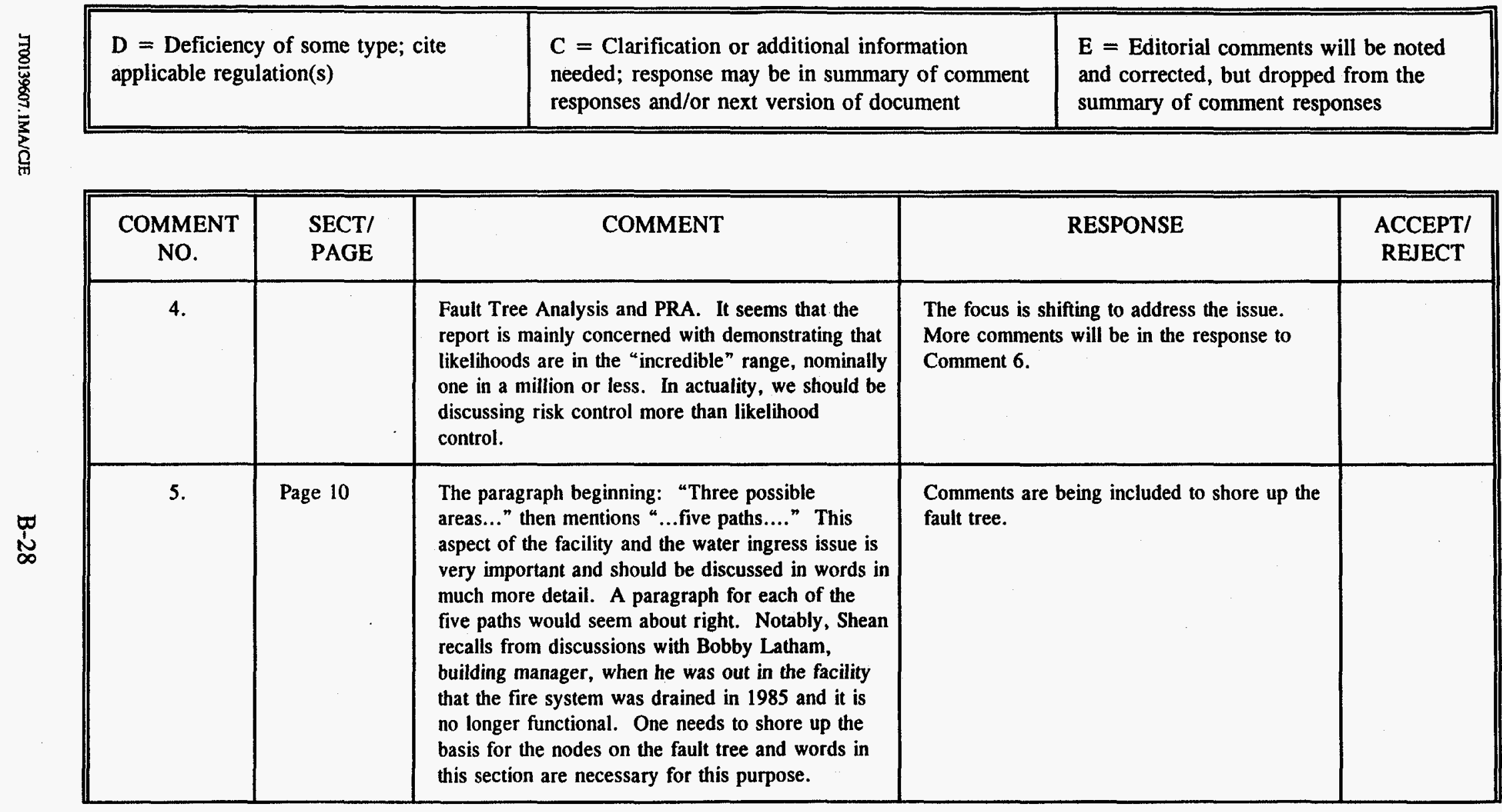


OAK RIDGE PROGRAM DIVISION DOCUMENT REVIEW FORM

\begin{tabular}{|c|c|c|c|c|c|}
\hline \multicolumn{2}{|c|}{$\begin{array}{l}D=\text { Deficiency of some type; cite } \\
\text { applicable regulation(s) }\end{array}$} & \multicolumn{2}{|c|}{$\begin{array}{l}\mathrm{C}=\text { Clarification or additional information } \\
\text { needed; response may be in summary of comment } \\
\text { responses and/or next version of document }\end{array}$} & \multicolumn{2}{|c|}{$\begin{array}{l}E=\text { Editorial comments will be noted } \\
\text { and corrected, but dropped from the } \\
\text { summary of comment responses }\end{array}$} \\
\hline $\begin{array}{l}\text { COMMENT } \\
\text { NO. }\end{array}$ & $\begin{array}{l}\text { SECT/ } \\
\text { PAGE }\end{array}$ & COMMENT & & RESPONSE & $\begin{array}{l}\text { ACCEPT/ } \\
\text { REJECT }\end{array}$ \\
\hline 6. & $\begin{array}{l}\text { Section } 2.2 .1 \text {, } \\
\text { next to last } \\
\text { sentence }\end{array}$ & $\begin{array}{l}\text { "... the probability... is } 2 \times 1.0^{9} . " \text { This is an } \\
\text { absurdly precise number. It implies that nothing } \\
\text { could have been overlooked at the } 1.0^{-8} \text { level, for } \\
\text { example, and none of us are that good. I } \\
\text { personally would have avoided the quantified PRA } \\
\text { approach. It raises too many questions as to the } \\
\text { validity of the input data (it is mostly from reactor } \\
\text { research) and its uncertainties and gives the } \\
\text { uninitiated a misleading impression about the } \\
\text { impossibility of the event as implied by the } \\
\text { absolute likelihood. Instead, I would have relied } \\
\text { on the deterministic calculations, which show that, } \\
\text { without water ingress, things are far subcritical, } \\
\text { and supported this by discussions of the state of } \\
\text { knowledge from past cleanouts, known valve } \\
\text { closures, the measures planned to be taken to } \\
\text { understand the current state of the deposits, remove } \\
\text { any standing water, etc., including written } \\
\text { operating procedures for the cleanout operations. } \\
\text { As stated previously, I would also have emphasized } \\
\text { more the risk than the likelihood issue. }\end{array}$ & $\begin{array}{l}\text { The documen } \\
\text { deterministic } \\
\text { process know } \\
\text { will be used t } \\
\text { ingress into th } \\
\text { tree is not the } \\
\text { evidence. }\end{array}$ & $\begin{array}{l}s \text { being revised to reflect } \\
\text { lculations and the use of } \\
\text { ige. The fault tree analysis } \\
\text { address the discussion of water } \\
\text { coolers. Therefore, the fault } \\
\text { ocus but rather the supporting }\end{array}$ & \\
\hline
\end{tabular}


OAK RIDGE PROGRAM DIVISION DOCUMENT REVIEW FORM

\begin{tabular}{|c|c|c|c|c|c|c|}
\hline \multicolumn{3}{|c|}{$\begin{array}{l}D=\text { Deficiency of some type; cite } \\
\text { applicable regulation(s) }\end{array}$} & \multicolumn{2}{|c|}{$\begin{array}{l}\mathrm{C}=\text { Clarification or additional information } \\
\text { needed; response may be in summary of comment } \\
\text { responses and/or next version of document }\end{array}$} & \multicolumn{2}{|c|}{$\begin{array}{l}\mathrm{E}=\text { Editorial comments will be noted } \\
\text { and corrected, but dropped from the } \\
\text { summary of comment responses }\end{array}$} \\
\hline $\begin{array}{l}\text { COMMENT } \\
\text { NO. }\end{array}$ & $\begin{array}{l}\text { SECT/ } \\
\text { PAGE }\end{array}$ & & COMMENT & & RESPONSE & $\begin{array}{l}\text { ACCEPT/ } \\
\text { REJECT }\end{array}$ \\
\hline 7. & & & $\begin{array}{l}\text { ommendations, while it may seem } \\
\text { would suggest some words to require } \\
\text { eposit removal be documented from a } \\
\text { ned perspective and the knowledge } \\
\text { onsidered in the planning of subsequent } \\
\text { ovals. }\end{array}$ & \multicolumn{2}{|c|}{ Noted. The document has been revised. } & \\
\hline 8. & Appendix B & & $\begin{array}{l}\text { report would be better simply } \\
\text { What would be valuable and is in fact } \\
\text { f this report, but should be, is a table of } \\
\text { alculations of relevant benchmark } \\
\text { This should already exist as it is } \\
\text { use unvalidated computer code/cross } \\
\text { s. }\end{array}$ & \multicolumn{2}{|c|}{$\begin{array}{l}\text { This appendix will be changed to show the } \\
\text { validation more clearly. }\end{array}$} & \\
\hline
\end{tabular}


OAK RIDGE PROGRAM DIVISION DOCUMENT REVIEW FORM

\begin{tabular}{|c|c|c|c|c|c|c|}
\hline \multicolumn{3}{|c|}{$\begin{array}{l}\mathrm{D}=\text { Deficiency of some type; cite } \\
\text { applicable regulation(s) }\end{array}$} & \multicolumn{2}{|c|}{$\begin{array}{l}\mathrm{C}=\text { Clarification or additional information } \\
\text { needed; response may be in summary of comment } \\
\text { responses and/or next version of document }\end{array}$} & \multicolumn{2}{|c|}{$\begin{array}{l}E \text { = Editorial comments will be noted } \\
\text { and corrected, but dropped from the } \\
\text { summary of comment responses }\end{array}$} \\
\hline $\begin{array}{l}\text { COMMENT } \\
\text { NO. }\end{array}$ & $\begin{array}{l}\text { SECT/ } \\
\text { PAGE }\end{array}$ & & COMMENT & & RESPONSE & $\begin{array}{l}\text { ACCEPT/ } \\
\text { REJECT }\end{array}$ \\
\hline 9. & Appendix C & & $\begin{array}{l}\text { dix could include some text to assist } \\
\text { iliar with this application to better } \\
\text { some of the important but unstated } \\
\text { example, the basic event frequencies } \\
\text { irgely from the reactor world and have } \\
\text { ect applicability. Relatedly, the } \\
\text { s on the frequencies are likely large, } \\
\text { no mention of uncertainties at all and } \\
\text { nt likelihood is simply reported as if it } \\
\text { solute value. This could readily give } \\
\text { iliar with this PRA application a } \\
\text { impression. As stated under Comment } \\
\text { no discussion of the reality that all fault } \\
\text { complete to some unknown degree and } \\
\text { ist take the results as indicators and not } \\
\text { s. }\end{array}$ & Noted. The & $t$ has been modified. & \\
\hline
\end{tabular}


OAK RIDGE PROGRAM DIVISION DOCUMENT REVIEW FORM

\begin{tabular}{|c|c|c|c|c|c|c|}
\hline \multicolumn{3}{|c|}{$\begin{array}{l}\mathrm{D}=\text { Deficiency of some type; cite } \\
\text { applicable regulation(s) }\end{array}$} & \multicolumn{2}{|c|}{$\begin{array}{l}\mathrm{C}=\text { Clarification or additional information } \\
\text { needed; response may be in summary of comment } \\
\text { responses and/or next version of document }\end{array}$} & \multicolumn{2}{|c|}{$\begin{array}{l}\mathrm{E}=\text { Editorial comments will be noted } \\
\text { and corrected, but dropped from the } \\
\text { summary of comment responses }\end{array}$} \\
\hline $\begin{array}{l}\text { COMMENT } \\
\text { NO. }\end{array}$ & $\begin{array}{l}\text { SECT/ } \\
\text { PAGE }\end{array}$ & & COMMENT & & RESPONSE & $\begin{array}{l}\text { ACCEPT/ } \\
\text { REJECT }\end{array}$ \\
\hline 10. & & & $\begin{array}{l}\text { above comments are not insignificant, let } \\
\text { size that there appear to be no recognized } \\
\text { criticality accident and no undue } \\
\text { with proceeding with cleanout operations. } \\
\text { the information that Shean and I have } \\
\text { sed to and based on prudent paths } \\
\text { which will consider the use of physical } \\
\text { water and for understanding fissile } \\
\text { ometry, then there should be no reason } \\
\text { vernmental regulations pertaining to } \\
\text { iticality safety, both DOE's and NRC's, } \\
\text { fully and cost-effectively complied with. }\end{array}$ & Noted. & & \\
\hline
\end{tabular}

